\title{
Taking Aristotle Seriously: Republican- Oriented Legal Theory and the Moral Foundation of Deliberative Democracy
}

\author{
Miriam Galston
}

Table of Contents

I. The Political Nature of Human Beings: Sacrifice or Self-Interest?................................... 339

A. Reliance on Aristotle's Statement About the Political Nature of Human Beings ........................ 340

B. The Meaning of "Nature" in Aristotle's Statement that Human Beings Are by Nature Political ............ 345

C. The Theoretical Basis for Aristotle's Statement that Human Beings Are by Nature Political ............. 349

D. Consequences of Aristotle's Interpretation of the Political Nature of Human Beings

II. Realizing Our Political Nature: The Approach of Contemporary Republican-Oriented Legal Theory ......... 354

A. Dialogue and the Scrutiny of Unexamined Opinion ..... 355

B. The Willingness to Talk, Listen, and Abide .......... 361

III. Realizing Our Political Nature: The Aristotelian Approach... 371

A. The Domain of Practical Reason for Aristotle and Contemporary Legal Theorists .................... 371

B. The Dependency of Practical Reason on Character ..... 372

C. The Development of Good Character .............. 376

IV. The Consequences of Aristotle's Ideas for the Contemporary Deliberative Project .................. 378

V. Aristotle's Reply to Contemporary Fears .............. 386

A. The Rational Capacity of Citizens ................ 387

B. The Multiplicity of Human Types ................ 391

Conclusion ....................................... 396 


\title{
Taking Aristotle Seriously: Republican- Oriented Legal Theory and the Moral Foundation of Deliberative Democracy
}

\author{
Miriam Galston $\dagger$
}

Contemporary legal theorists who voice civic republican or communitarian concerns appeal frequently to Aristotle's writings. Despite the carefully reasoned and scholarly approach of such theorists, they often rely on Aristotle in a perfunctory manner, treating isolated propositions in his works as philosophic catechisms. This is particularly ironic given Aristotle's own emphasis on the importance of contextual, as contrasted with abstract, arguments for political discourse. In this Article, the author begins the task of recovering Aristotle in context. In particular, the author focuses on one of the core concerns of republican-oriented legal theory: creating a more deliberative or reflective political life. Analyzing Aristotle's views on the relationship between character and reason-in particular, his belief that the ability of an individual to be rational or reasonable depends upon the presence of certain character traits-the author argues that communities must provide for the moral education of their members in order to make politics more deliberative.

It is commonplace to exhort the reader to take things seriously. ${ }^{1}$ Nonetheless it may appear superfluous to ask lawyers and law professors to

Copyright @ 1994 California Law Review, Inc.

$\dagger$ Associate Professor, The George Washington University, National Law Centcr. B.A. Cornell University, 1967; Ph.D. University of Chicago, 1973; J.D. Yale Law School, 1982. The National Law Center has provided generous support for this project. I am also grateful to friends and colleagues who read earlier versions of this article for their wise counsel, especially Cheryl Block, Bill Galston, Philip Hamburger, Chip Lupu, Frank Michelman, Larry Mitchell, Tom Morgan, and Mark Tushnet. Debra Erenberg, Dina Gold, Wendy Hannon, and Mark Schultz provided valuable research assistance. This article is dedicated to the memory of Jack Stcinberg, iny father.

1. See Walter Berns, Takng the Constitumion Seriously (1987); Ronald Dworkin, Taking Rights Seriously (1977); Michael W. McCann, Taking Reform Sertously: Perspectives on Publtc InTerest Liberalism (1986); Akhil R. Amar, Taking Article III Seriously: A Reply to Professor Friedman, 85 Nw. U. L. Rev. 442 (1991); Thomas M. Franck, Taking Treaties Seriously, 82 AM. J. INr'L L. 67 (1988); Stephen Gillers, Taking L.A. Law More Seriously, 98 YALE L.J. 1607 (1989); Neil K. Komesar, Taking Institutions Seriously: Introduction to a Strategy for Constitutional Analysis, 51 U. CHI. L. REv. 366 (1984); Reinier Kraakman, Taking Discounts Seriously: The Implications of "Discounted" Share Prices as an Acquisition Motive, 88 CoLUM. L. REv. 891 (1988); Tracey Maclm, Justice Thurgood Marshall: Taking the Fourth Amendment Seriously, 77 CORNELL L. Rev. 723 (1992); Aleksander Peczenik, Taking Laws Seriously, 68 CoRNell L. Rev. 660 (1983); Robin West, The Supreme Court, I989 Term-Foreword: Taking Freedom Seriously, 104 HARv. L. REv. 43 
take Aristotle seriously. Law review articles, ${ }^{2}$ the Supreme Court, ${ }^{3}$ and other federal ${ }^{4}$ and state ${ }^{5}$ courts have cited Aristotle and his views hundreds of times. Legal scholars have appealed to Aristotle in connection with questions as diverse as justice in tort law, ${ }^{6}$ climical education's importance for the development of professional responsibility, ${ }^{7}$ society's responsibility to provide public assistance to the disabled, ${ }^{8}$ grading methods for law school exams, ${ }^{9}$ the desirability of adjudicating the constitutional claims of military personnel under a "separate community" standard, ${ }^{10}$ and aspects of the crimmal justice system. ${ }^{11}$ The vast majority of these references look to Aristotle's writings in moral and political philosophy. ${ }^{12}$

(1990) [hereinafter West, Taking Freedom Seriously]; Robin L. West, Taking Preferences Seriously, 64 Tur. L. Rev. 659 (1990); Note, Taking Reichs Seriously: German Unification and the Law of State Succession, 104 HARv. L. Rev. 588 (1990); William E. Forbath, Taking Lefis Seriously, 92 YALB L.J. 1041 (1983) (book review); Mark Kelman, Taking Takings Seriously: An Essay for Centrists, 74 CALIP. L. REv. 1829 (1986) (book review); Douglas Laycock, Taking Constitutions Seriously: A Theory of Judicial Review, 59 TEx. L. Rev. 343 (1981) (book review); William M. Treanor, Taking the Framers Seriously, 55 U. CHI. L. Rev. 1016 (1988) (book review).

2. A LEXIS search conducted on December 1, 1993 in the LAWREV library and the ALLREV file using the search term "Aristot!" retrieved 1080 law review articles.

3. A LEXIS search conducted on December 1,1993 in the GENFED library and the US file found nine Supreme Court opinions referring to Aristotle or Aristotelian views. See Antonin Scalia, The Rule of Law as a Law of Rules, 56 U. CHr. L. Rev. 1175, 1182 (1989) (announcing that "1 stand with Aristotle" in endorsing rule formalism).

4. A LEXIS search conducted on December 1, 1993 in the GENFED library and the USAPP and DIST files found 125 federal appellate and district court decisions referring to Aristotle or Aristotelian views.

5. A LEXIS search conducted on December 1, 1993 in the STATES library and the COURTS file found 133 state court decisions referring to Aristotle or Aristotelian views.

6. See Jules Coleman, Corrective Justice and Wrongful Gain, 11 J. LEgAL Stud. 421, 433.36 (1982); Robert Cooter, Torts As the Union of Liberty and Efficiency: An Essay on Causation, 63 CH1.KENT L. Rev. 523, 546-47 (1987).

7. See Phyllis Goldfarb, A Theory-Practice Spiral: The Ethics of Feminism and Clinical Education, 75 MiNN. L. REv. 1599, $1662-67$ (1991) [hereinafter Goldfarb, Theory-Practice Spiral]; David Luban, Epistemology and Moral Education, 33 J. LEOAL Educ. 636, 637, 650-61 (1983).

8. See Peter B. Edelman, The Next Century of Our Constitution: Rethinking Our Duty to the Poor, 39 HASTINGs L.J. 1, 22-23 (1987).

9. See Philip C. Kissam, Law School Examinations, 42 VAND. L. Rev. 433, 445-51 (1989).

10. See James M. Hirschhorn, The Separate Community: Military Uniqueness and Servicemen's Constitutional Rights, 62 N.C. L. REv. 177, 250-51 \& n.394 (1984).

11. Stephen J. Morse, Excusing the Crazy: The Insanity Defense Reconsidered, 58 S. CAL. L. Rev. 777, 782 (1985); Benjamin B. Sendor, Crime As Communication: An Interpretive Theory of the Insanity Defense and the Mental Elements of Crime, 74 GEo. L.J. 1371, 1372-73 (1986).

12. Of these, the most intportant are the Nicomachean Ethics, the Eudemian Ethics, and the Politics, although Aristotle's Protrepticus and Constitution of Athens are occasionally mentioned as well. Throughout this article, Aristotle's works will be cited to the Oxford Classical Text editions using the Bekker pagination that is printed in the margins. On the relationship between the Nicomachean Ethics and the Politics, see THE Poumics Of ARIsTOTLE at xxxv, 353 (Ernest Barker trans., 1962) and infra note 266 and accompanying text. See generally 1 SiR AleXANDER Grant, THE Ethics of Aristotre, Illustrated with Essays and Notes app. C at 410-13 (Amo Press 1973) (1875) [heremafter GRANT, THE ETHICS OF ARISTOTLE] (arguing that Aristotle at times presents politics as the end of ethics and at times acknowledges the absolute worth of the individual by maintaining a complete separation between politics and ethics); A.W.H. Adkins, The Connection between Aristotle's Ethics and Politics, 12 Pol. Theory 29 (1984), reprinted in A Companion to Aristotle's Polst/cs 75 (David 
Legal theorists who voice civic republican or communitarian concerns are among those who have frequent recourse to Aristotle's authority in their writings. ${ }^{13}$ Although these theorists actually conprise a very heterogeneous group, ${ }^{14}$ and several consider theniselves to be niamstream or niodified

Keyt \& Fred D. Miller, Jr. eds., 1991) (focusing on the question of the relationship between the good man and the good citizen in these two works). On the Eudemian Ethics, see generally ARISTOTLE's EUDEMIAN ETHICS: BOoKS I, II, AND VIII (Michael Woods trans., 1982). On the relationship between the Eudemian Ethics and the Nicomachean Ethics, see generally JOHN M. COOPER, REASON AND HUMAN Good IN ARISTOTLE 144-80 (1975) (comparing the account of happiness in the Nicomachean Ethics with that in the Eudemian Ethics); ANTHONY KeNNY, The ARISTOTELIAN Ethics: A STUDY of THE

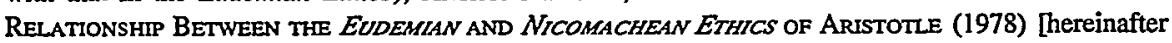
KENNY, THE ARISTOTELIAN ETHICs] (based on a statistical analysis of vocabulary, other stylistic features, and an analysis of philosophical issues, Keuny argues that the Eudemian Ethics was viewed in the ancient world as Aristotle's main ethical work and that the Books common to it and the Nicomachean Ethics were first written as part of the Eudemian Ethics and later added to the Nicomachean Ethics); ANthony KenNy, Aristotle on the Perfect Life app. 1, at 113-42 (1992) (updating and revising his I978 study); J. Donald Monan, Moral KNowledge and ITS METHODOLOGY IN ARISTOTLE 37-59, 151-56 (1968) (reviewing current interpretations of the relationship between the two works and summarizing his own view); T.H. Irwin, Book Review, 77 J. PHIL. 338 (1980) (reviewing ANTHONY KeNNY, ARISTOTELIAN EthICS (1978) and ANTHONY KeNNY, ARISTOTLE's THEORY OF THE WIIL (1979)).

13. The expression "civic republicans" has a meaning similar to the earlier expression "civic humanists," which, in turn, has a meaning similar to "classical republicans." See J.G.A. Pocock, Virtues, Rights, and Manners: A Model for Historians of Political Thought, 9 POL. THEORY 353, 354-55 (1981) [hereinafter Pocock, Virtues, Rights, and Manners] (asserting that both civic humanism and classical republicanism posit that "homo is naturally a citizen and most fully himself when living in a vivere civile"). However, most contenporary writers distinguish contemporary civic republicanism from the classical republicanism of Greek thinkers. One of the leitunotifs of this Article is the various points of disagreement between classical republicanism and its contemporary offspring. See, e.g., West, Taking Freedom Seriously, supra note 1, at 60-61 (stating that civic republicanism, like classical republicanism, values "communal political life and a collective, deliberative dialogue that articulates the shared values that should be at the center of that life," but rejects "the conformity, homogeneity, and militaristic zeal" of the earlier version). The label "communitarian" is of more recent vintage, and it is often used interchangeably with "civic republican" to describe theorists who endorse some or all of the views described in the text that follows. But see Drucilla Comell, Beyond Tragedy and Complacency, 81 Nw. U. L. REv. 693, 695 n.9, 697 n.11 (1987) (distinguishing civic republicans from "dialogic coinmunitarians" in that the latter do not limit their ideals to the intent of the founders, and they value individual freedom, not just collective self-governance). For the view that we should discard the labels "communitarian" and "liberal," see Charles Taylor, Cross-Purposes: The Liberal-Communitarian Debate, in Liberalism and the MORAL LIFE 159, 163 (Nancy L. Rosenblum ed., 1989) [hereinafter Taylor, Cross-Purposes] (arguing that these labels mask the multiplicity of basic issues associated with each point of view).

14. The legal theorists most frequently cited as spearheading the republican revival are Cass Sunstein, Frank Michelman, Suzanna Sherry, and Michael Perry. See Lawrence B. Solum, Virtues and Voices, 66 CHr.-KeNr L. Rev. 111, 112 \& n.9 (1990) (mentioning Linda Hirshınan, Pnina Lahav, James Gray Pope, and Mark Tushnet in addition to the above list); Ronald Kahn, Pluralism, Civic Republicanism, and Critical Theory, 63 TuL. L. Rev. 1475, 1475 (1989) (listing Levinson and Tushnet in addition to Perry). Solum describes his own work as "broadly liberal." Solum, Virtues and Voices, supra, at 113 n.13. While Richard Fallon discusses Mark Tushnet as a major civic republican figure, he adds that "Tushnet is in many ways half-hearted and anbivalent about his embrace of republicanism" and that Sunstein and Michelman are "less anibivalent republican revivalists." Richard H. Fallon, Jr., What Is Republicanism, and Is It Worth Reviving?, 102 HARv. L. REv. 1695, 1699 (1989). But Fallon also notes that Sunstein, whose views Fallon finds attractive, characterizes his own goal as developing a kind of "liberal republicanism," committed to mcorporating such good things as rights, equality, and neutrality into his model. Id. at 1730-32; see Cass R. Sunstein, Beyond the Republican Revival, 97 
liberals, ${ }^{15}$ all discuss one or more of such republican themes as the intellec-

YALE L.J. 1539, 1541-42, 1566-71 (1988) (defining "liberal republicanism"). Fallon also obscrves that Miclıelman, who is frequently included among civic republican theorists, "draws his central historical inspiration not from Aristotle . . . but from the liberal holy of holies, Immanuel Kant." Fallon, supra, at 1730; see Frank I. Michelman, The Supreme Court, 1985 Term-Foreword: Traces of Self-Government, 100 Harv. L. REv. 4, 26-30 (1986) [hereinafter Michelman, Traces of Self-Government] (referring to Kant). For other classifications of legal scholars, see Stephen A. Gardbaum, Law, Politics, and the Claims of Community, 90 Mrch. L. REv. 685, 690 (1992) (adding the following "legal communitarians" to the above lists: Owen Fiss, Robert Cover, Roberto Unger, Duncan Kennedy, and Robert Bork); John J. Gibbons, Intentionalism, History, and Legitimacy, 140 U. PA. L. Rev. 613, 643-44 (1991) (associating Bruce Ackerman, Cass Sunstein, Frank Michelman, and Mark Tushnet with republicanism); Cass R. Sunstein, Interest Groups in American Public Law, 38 Stan. L. Rev. 29, 30 n.7 (1985) [hercinafter Sunstein, Interest Groups] (noting significant authors (as of 1985) in the republican revival in history, political theory, and legal theory); West, Taking Freedom Seriously, supra note 1, at 62 n.109 (noting "republican" arguments of Paul Brest in Further Beyond the Republican Revival: Toward Radical Republicanism, 97 YALE L.J. 1623 (1988)).

15. For example, Suzanna Sherry describes her own approacl as "feminine jurisprudence." Suzanna Sherry, Civic Virtue and the Feminine Voice in Constitutional Adjudication, 72 VA. L. REv. 543, 544 (1986) [hereinafter Sherry, Civic Virtue]. Femimine jurisprudence "might embrace" "the communitarian and virtue-based framework of Jeffersonian republicanism." $1 d$. Sherry also characterizes her project as reconciling the liberal and the republican traditions rather than rcplacing the liberal with the republican. Id. at 578 .

Sunstein appears to endorse the ideas he attributes to the founders, especially the Fcderalists, who abandoned civic virtue but retained a belief in a deliberative democracy. Sunstein, Interest Groups, supra note 14, at 46-47. Sunstein calls the Founders' rejection of selfisl pluralism and their expcctation that representatives would have civic virtue "Madisonian republicanism' . . ., which occupies an intermediate position betwecn interest-group pluralism and traditional republicanism." Id. at 47-48; see Sunstein, Bcyond the Republican Revival, supra note 14, at 1558-64 (detailing interplay of pluralist and republican thought in Founders' political theory). In Bcyond the Republican Revival, Sunstein adopts and elaborates a "liberal republicanism," which is "not antiliberal at all." Id. at 1541; see id. at 1567 (arguing that liberal republicanism can be "the antonym of the species of republicanism that operated during the constitutional period" only through a "caricature" of the liberal tradition); Cass R. Sunstein, Administrative Substance, 1991 DuKE L.J. 607, 612-16 (describing liberal republicanism). Contra Sherry, Civic Virtue, supra, at 561 (arguing that the Constitution is liberal, not republican).

Frank Michelman identifies himself with the republican tradition. Frank Miclielman, Law's Republic, 97 YALE L.J. 1493, 1499, 1514, 1525 (1988). Nonetheless he rejects certain views traditionally associated with that tradition, such as civic virtue and a unitary common good, in favor of a brand of republicanism emphasizing practical reason and dialogue. Michelman, Traces of SelfGovernment, supra note 14, at 36-47. Michelman's republicanism is also deeply inclusory and committed to pluralism, which he sees as a condition of meaningful dialogue. Michelman, Law's Republic, supra, at 1495, 1505-07.

Like Sunstein, Bruce Ackerman states that one of his aims is "to question the dichotomy betwcen liberalism and republicanism." 1 Bruce ACKerman, We the People: Foundations 29 (1991) [hereinafter, ACKerman, We the PEOPLE]. Ackerman's interpretation of American constitutional theory finds in it a strong individualist liberal component ("normal politics") coupled with a more communal and deliberative republican-oriented conponent ("constitutional monents"). Id. at 6-7, 1921, 29-33, 9I; see Bruce A. Ackerman, The Storrs Lectures: Discovering the Constitution, 93 YALE L.J. 1013, 1022-23 (1984).

Robin West classifies herself as a liberal. See Robin L. West, Liberalism Rediscovered: A Pragmatic Definition of the Liberal Vision, 46 U. PrTT. L. REv. 673, 674-77 (1985) [hereinafter Wcst, Liberalism Rediscovered], where she develops a theory of "pragmatic liberalism," and West, Taking Freedom Seriously, supra note 1, at $46-47$, where she rejects what she calls legal liberalism and appears to endorse the type of liberalism elaborated by Vaclav Havel. Although her views are in the last analysis deeply individualistic, several aspects of her theory reflect republican concerns. One exaniple is her belief that we must pursue the good life and that the content of the good life is only knowable through a communal inquiry. See West, Liberalism Rediscovered, supra, at 673-74, 680-83. A second 
tual and moral poverty of the more individualistic theories of liberalism and their emphasis on rights; the importance of strengthening communal bonds among citizens; the concomitant need for participation in political activity animated by a commitment to the public interest or the common good; the distimction between people's spontaneous preferences or felt needs and their true and permanent interests; and the desirability of deliberative or reasoned public decisioninaking processes. ${ }^{16}$

Legal theorists address these issues in order to reform and invigorate American democratic processes, whether at the level of judicial review, legislation, or public awareness and participation in politics. Although their ultimate purpose is thus practical, ${ }^{17}$ their mode of analysis is im general

example is her emphasis on the moral responsibilities of leaders and citizens. See West, Taking Freedom Seriously, supra note 1, at 65-66, 72-74 (according to Havel, responsibility for oneself, not rights, establishes a person's identity and freedom, and responsibility for others ensures a free society). For a more recent and developed statement of liberalism embedded in pragmatic philosophy, see generally Charles W. Anderson, Pragmatic Liberalism (1990).

A vast literature has grown up discnssing the relationship between liberalisin and republicanisin. See, e.g., Richard A. Posner, The Problems of Jurisprudence 414 (1990) (liberalism and communitarianism are mutually exclusive legal theories); C. Edwm Baker, Republican Liberalism: Liberal Rights and Republican Politics, 41 FLA. L. REv. 491, 494 (1989) (stating that our constitutional vision can be characterized as "republican liberalism" that, in part, requires common goods to be advanced only in a inanner consistent with liberal rights); Ronald Beiner, What's the Matter with Liberalism?, in LAw AND THE COMMUNTY: THE END OF INDIVIdUALISM? 37, 45 (Allan C. Hutchinson \& Leslie J.M. Green eds., 1989) (writing that "liberalism itself is unavoidably a communitarian theory" given certain assumptions); Gardbaum, Law, Politics, and the Claims of Community, supra note 14, at 686-90 (communitarian legal theory's attack on liberalism is inarked by confusion over what the claims of community are); Mark Seidenfeld, A Civic Republican Justification for the Bureaucratic State, 105 HARV. L. REv. 1511, 1528 (1992) ("Civic republicanism lias evolved as a concurrence of liberal and republican theory that simultaneously seeks to foster individual freedom from government-inposed values and freedom collectively to define the values of the relevant political community.").

16. For further discussions of the core tenets of conteinporary republicanism, see Fallon, What is Republicanism and Is It Worth Reviving, supra note 14, at 1697; Gardbaum, Law, Politics, and the Claims of Community, supra note 14, at 723-30; Steven G. Gey, The Unfortunate Revival of Civic Republicanism, 141 U. PA. L. REv. 801, 804-33 (1993) [hereinafter Gey, The Unfortunate Revival]; Sunstein, Administrative Substance, supra note 15, at 612-16. For an examination of the conteinporary republicanism of political theorists, see Allen E. Buchanan, Assessing the Communitarian Critique of Liberalism, 99 Ertucs 852, 852-56 (1989) (concluding that liberalism's belief that government should protect basic individual civil and political rights survives the communitarian critique, although such rights can be justifiably overridden to protect the good of the community); Amy Gutmann, Communitarian Critics of Liberalism, 14 PrIL. \& PUB. AfF. 308 (1985) (reviewing communitarian attacks on liberalism's eniphasis on individual rights); Taylor, Cross-Purposes, supra note 13, at 172 (comparing liberalism's idea of society requiring a value-neutral government with the communitarian and republican idea of society requiring a conception of a common good).

17. Nonetheless these legal theorists are criticized for not being practical enough. See Rosa Eckstein, Comment, Towards a Communitarian Theory of Responsibility: Bearing the Burden for the Unintended, 45 U. Mramr L. Rev. 843, 893 (1991) (arguing that communitarian authors do not offer a "viable, tangible alternative" to liberalism). For a comparable critique of communitarian political theorists, see Thomas A. Spragens, JR., Reason AND Democracy 7-8 (1990) (inost major communitarian political works have been critiques of liberal individualism; "[w]hen it comes to providing a constructive and affirmative philosophical foundation for the communitarian viewpoint, we find rather thin fare"). According to Linda Hirshman, the problem is not simply a failure to focus on concrete practical suggestions; rather, these communitarian theorists' practical failings sten from a profound theoretical blindness. Linda R. Hirshman, The Virtue of Liberality in American Communal 
carefully reasoned and scholarly. Yet for the most part, contemporary legal theorists rely on Aristotle im a perfunctory manner. Even when Aristotle is cited, his views are quoted summarily or in a conclusory fashion, like axioms of geometry too obvious to warrant discussion. ${ }^{18}$

This tendency is odd for two reasons. First, Aristotle was a suprennely dialectical writer. Although famous for being the first philosopher to offer a systematic account of syllogisins and deinonstrative reasoning, ${ }^{19}$ the hallmark of his style in his pohtical and moral works is its investigative or exploratory character. ${ }^{20}$ Thus, to treat isolated propositions in Aristotle's

Life, 88 Mich. L. REv. 983, 985-86 (1990) (arguing that civic republican legal theorists cannot "articulate a satisfying version of a common life without a theory of the good life," which they shun out of fear of its authoritarian and élitist implications).

18. There are a few notable exceptions. See, e.g., Donald F. Brosnan, Virtue Ethics in a Perfectionist Theory of Law and Justice, 11 Cardozo L. Rev. 335 (1989) [hereinafter Brosnan, Virtue Ethics]; Linda R. Hirshman, The Book of "A," 70 Tex. L. REv. 971 (1992); Solum, Virtues and Voices, supra note 14 , at 114-17, 119-22, 127-29.

19. Deinonstrative reasoning is the subject of Aristotle's Prior Analytics and Posterior Analytics. Briefly, it combines true, necessary, and primary premises within a rigorous syllogistic structure to reach true and necessary conclusions. See Aristotze, Posterior ANAlytics 1.2; Aristotle, Topics 1.1 100a27-b21. So defined, demonstrative reasoning appears to be more scientific or rigorous than dialectical reasoning. As a consequence, some scholars have concluded either that Aristotle discovered the method of demonstration after he discovered the inethod of dialectic or, regardless of the order of discovery, that he saw the method of demonstration as superseding the method of dialectic in most areas of philosophic investigation. See, e.g., D.W. Hamlyn, Aristotle on Dialectic, 65 PHILosophy 465, 473 76 (1990) (maintaining that dialectic is not part of the search for truth in itself, although it may play a significant role in enabling people to understand or accept first principles); Pamela M. Huby, The Date of Aristotle's Topics and its Treatment of the Theory of Ideas, 12 CLAssiCal Q. (n.s.) 72, 76 (1962) (stating that Aristotle's discovery of syllogisıns and the rigorous arguments of demonstrative reasoning caused him to give a lower place to dialectic); Friedrich Solinsen, Dialectic Without the Forms, in Aristotle on Dialectic: The Topics 49, 53-55 (G.E.L. Owen ed., 1968) (arguing that Aristotle placed philosophical and mathematical syllogisms above dialectic, which he assumed proceeds only from opinion); Joseph Moreau, Aristote et la dialectique platonicienne, in ARIstotLE on DiAlectic: ThE Topics, supra, at 80, 83-85 (stating that dialectic was the supreme "scientific" method in Platonic philosophy until Aristotehan demonstrative reasoning replaced it). For the contrary vicw, i.e., that Aristotle did consider dialectic as part of philosophic investigation, sce J.D.G. Evans, ARISTOTLE's CONCEPT OF DIALECTIC 3-6, 75-94 (1977) (developing the thesis that dialectic is critical for establishing the foundations of the sciences because it enables the investigator to move from what is intelligible relative to individuals to what is intelligble without qualification); Roger Crisp, Aristotle on Dialectic, 66 PHILOSOPHY 522, 523 (1991) (asserting that dialectic has two uses: winning debates and philosophic investigation); Miriam Galston, Aristotle's Dialectic, Refutation, and Inquiry, 21 Dialogur 79, 91-93 (1982) (arguing that dialectic is part of philosophic investigation, and not just a prelude to it, and describing how dialectic is able to transcend generally accepted opinion); Terence H. 1rwin, Aristotle's Methods of Ethics, in Studies in ArIstotle 193, 194-201 (Dominic J. O'Meara ed., 1981) (describing the philosophic use of dialectic in the Nicomachean Ethics). The most important recent work on Aristotle's method of dialectic is Terence IrwiN, ArISTOtLe's First Principles 14-25 (1988) (distinguishing between Aristotle's pure dialectic, which reasons from generally accepted beliefs to attain coherence ainong beliefs, and his strong dialectic, which selects its premises more rigorously; and arguing that Aristotle's philosophical treatment of the nature of being in the Metaphysics as well as certain of the discussions in his other writings procecd through strong dialectie).

20. See Mary P. Nichols, Citizens and Statesmen: A Study of ARistotle's Polmtics 7.8 (1992) [hereinafter Nichols, Crizens and Statesmen) (inaintaining that Aristotle employs the method of dialectic in the Politics to create a political debate in which he both teaches and learns; thus, lie "rules and is ruled in turn"); Stephen G. Salkever, Finding the Mean: Theory and Practice in 
works as philosophic catechisms does violence to a core aspect of the philosopher's own method. Second, many of the authors who cite Aristotle emphasize his theory of practical reasoning as part of a larger argument stressing the importance of contextual, as contrasted with abstract, arguments for political discourse. ${ }^{21}$ It is ironic, therefore, that contemporary authors who value this dimension of Aristotle's thought nevertheless adopt particular statements made by Aristotle and repeat them as universal truths without considering the extent to which the plausibility of the statements depends upon the context in which they are made and upon related views presented in Aristotle's other works. In some instances, this irony is particularly acute because Aristotle's statements taken in context are less supportive of contemporary views than the same statements viewed in isolation.

My purpose in this Article is to begin the task of recovering Aristotle in context. ${ }^{22}$ The substantive focus of the Article is an issue that has frequently engaged contemporary legal theorists with republican concerns: creating a more deliberative or reflective political life. ${ }^{23}$ In the process, I address related issues - such as the importance of communal ties for being

Aristotelian Polmical PhILOsophy 4-5 (1990) [hereinafter Salkever, Finding the Mean] (stating that Aristotle's political writings should be seen as supplying a method of argument rather than a set of absolutely certain solutions); Martha C. Nussbaum, Comments, 66 CHI.-KeNr L. Rev. 213, 213 (1990) (asserting that the classical philosophical tradition should be seen "not as a tradition of positions, but as a tradition of argument and counter-argument").

21. See Katharine T. Bartlett, Feminist Legal Methods, 103 Harv. L. Rev. 829, 850-58 (1990) (maintaiming that feminist legal methods employ practical reasoning in which legal resolutions are responses to specific, real-life problems rather than abstract derivations that inevitably exclude the perspective of nondominant groups); Goldfarb, Theory-Practice Spiral, supra note 7, at 1636-37, 1666 67 (stating that clinical education reflects the Aristotelian process of reasoning from the circumstances of a given context to form an ethical judgment); Hirshman, The Book of "A," supra note 18, at 978-79 (describing the Aristotelian concept of practical reason and asserting that its emphasis on particularity, flexibility, concreteness, and context mirror the basic elements of feminist practical reason).

Legal theorists who are not fundamentally republican in their orientation have also shown interest in practical reasoning. See Gerald Dworkin, Philosophy, Law, and Politics, 72 Iowa L. Rev. 1355, 1356 (1987) ("[W]e ought to recognize the Aristotelian view that how we ought to live cannot be determined by any formulable list of general principles."); Daniel A. Farber \& Philip P. Frickey, Practical Reason and the First Amendment, 34 UCLA L. REv. 1615, 1616-17, $1645-47$ (1987) (describing the shift in focus from grand theory, foundational justifications, and narrowly objective, logical approaches to situational accounts of practical judgment); Anthony T. Kronman, Living in the Law, 54 U. CHI. L. REv. 835, 846-47 \& n.21 (1987) (stating that Aristotle was one of the few philosophers to address the subject of judgment).

22. This Article can thus be seen as contributing to the larger project undertaken by some legal theorists to clarify contemporary republican legal theory by elaborating the nonlegal sources of its basic concepts and ideas. See, e.g., Gardbaum, Law, Politics, and the Claims of Community, supra note 14, at 690-732 (providing a moral and political framework for understanding the claims of community in legal theory).

23. This Article assunies the desirability of a nore deliberative political community. For criticism of the deliberative ideal, see infra note 91. For a discussion of the place of the deliberative ideal in American constitutional law, see Paul W. Kahn, Reason and Will in the Origins of American Constitutionalism, 98 YALE L.J. 449, 454-61 (1989) [hereinafter Kahn, Reason and Will] (discussing the Founders' belief that political freedom presupposes a regime in which the governed reflect as well as choose their form of government). But see id. at 450, 494-502 (arguing that at the time of the founding, the reigming political theory emphasized the rational or scientific nature of the American Constitution in 
human-through the prism of the deliberative ideal. ${ }^{24}$ However, my concern in this Article is not with public spiritedness or civic virtue understood as ends in themselves, but only as means to facilitate the deliberative ideal. Based upon Aristotle's views on the relationship between character and reason-m particular, his belief that the ability of an individual to be rational or reasonable depends upon the presence of certain character traits-I conclude that the contemporary project of making politics more deliberative depends for its success on communities providing for the moral education of their members.

Part I begins by examining how one of the most frequently repeated statements from Aristotle's writings-that man is by nature political-is used by several leading legal theorists and commentators who give voice to civic republican or communitarian concerns. ${ }^{25}$ Part I explores a contradiction im the works of the authors who adopt this Aristotelian dictum yet develop a theory of civic virtue that requires the sacrifice of a person's own interests to the public interest. I argue that there is a tension between the view that politics requires citizens to sacrifice their self-interest and the belief that human nature is fundamentally political. This tension is partially alleviated if one accepts Aristotle's definition of human nature as the end or perfection of human life rather than interpreting it as a spontaneous or innate human tendency.

The rest of the Article examines the consequences for contemporary republican-oriented legal theory of adopting the Aristotelian notion of human nature as human perfection. Understanding human nature as an end to which people aspire and toward which people must labor creates a series of motivational problems for attaining a more deliberative political community. Part II reviews the methods advanced by contemporary republicanoriented theorists for enhancing the deliberative character of public discourse and decisionmaking. I argue that these theorists fail to address adequately the motivational questions implicit in their theories because they have not considered seriously the moral prerequisites of rational discourse, i.e., the extent to which the deliberative ideal will be difficult, if not impos-

addition to the importance of consent, whereas by the middle of the nineteenth century the focus had shifted to the consent of the governed exclusively).

24. For example, if a person cannot recognize situations in which there is a public interest at variance with that person's private interest, the person's ability to deliberate effcctively about the best course of action will be impaired.

25. I try to avoid using such labels as "communitarian theorists" or "republican thcorists" in order to focus on the broader and more diverse group of legal theorists sharing all or most of the conccrns enumerated in the text above. I often use the shorthand "republican-oriented" theory or theorists. As was noted earlier, supra notes 14-15, the legal theorists who share these concerns do not in fact represent a single school of thought, nor do they necessarily view themselves as civic republicans or communitarians. Because of this, I situate the use of Aristotelian and republican-oriented views made by imdividual authors within the context of each author's own teachings.

Although this Article's major focus is legal theorists, political theorists who address the same issues are also discussed. In general, however, the weaknesses I identify in the works of the legal theorists are less characteristic of the writings of political theorists. See infra Part IV. 
sible, to attain if public institutions remain neutral concerning the character and moral beliefs of citizens.

Part III contrasts this shortcoming of the conteinporary approacl with Aristotle's teachings about the relationships among character, reason, and reasonableness. This Part explores Aristotle's explanations for reason's dependence on character in two situations: first, in enabling a person to attain a rational grasp of practical matters and, second, in motivating a person to act in accordance with that understanding once attained.

Part IV offers an outline of the direction republican-oriented legal theory should take if Aristotle's insights about the relationship between character and reason are correct. This Part also reviews recent work by political theorists and moral philosophers who aspire to a more deliberative political community within the context of the principles characteristic of liberal political life. These political theorists share the belief that public institutions must actively engage im the moral education of citizens.

Part $\mathrm{V}$ addresses some of the most inportant objections made against attempts to place moral questions on the public agenda. In response to critics' concerns that publicly sponsored moral education will make people less rather than more deliberative, I argue, based upon classical and contemporary sources, that moral upbringing need not undermine people's capacity to identify and examine critically their inherited values and way of life. In connection with critics' concerns that publicly sponsored moral education will lead to excessive homogeneity, I examine the strand of Aristotle's writings suggesting that human nature is not primarily political after all. This strand tends to be ignored by contemporary legal theorists who voice republican concerns, even though it receives considerable attention from classicists and students of philosophy. I review the evidence that Aristotle's writings contain two fundamentally distinct portraits of human nature, one theoretical and one political. One implication of this dichotomy for conteinporary republican-oriented legal theorists is that Aristotle's moral teachings are compatible with multiple conceptions of the good life.

I

The Political Nature of Human Beings: Sacrifice or SELF-INTEREST?

Near the beginning of the Politics, Aristotle states that it is evident from his preceding discussion that the city is one of the things that exist by nature and that man is by nature a political animal. ${ }^{26}$ This staternent, and its

26. ARISTOTLE, Poltics 1.2 1253al-3. This passage has been translated in various ways. "From these things therefore it is clear that the city state is a natural growth, and that man is by nature a political ammal." Id. (Rackham trans., 1972). "From these considerations it is evident that the polis belongs to the class of things that exist by nature, and that man is by nature an animal intended to live in a polis." Id. (Emest Barker trans., 1962). "Hence it is evident that the state is a creation of nature, and that man is by nature a political animal." Id. (Benjamin Jowett trans., 1905). For interpretations of 
implications for the desirability of political life, is identified frequently with civic republican theory. ${ }^{27}$ This Part discusses several contemporary legal theorists with republican concerns who have had recourse, directly or indirectly, to Aristotle's insight. Although their theories differ, several of these authors assert the centrality of political life for people's ability to pursue and achieve fulfillment. Somewhat paradoxically, they also take the position that involvement in political life entails a large measure of sacrifice. This Part discusses this inconsistency and attempts to resolve it by recourse to Aristotelian principles.

\section{A. Reliance on Aristotle's Statement About the Political Nature of Human Beings}

Suzanna Sherry is one of the most frequently cited republican-oriented legal theorists. ${ }^{28}$ In proposing a "feminine jurisprudence" or a "feminine vision" of constitutional theory to broaden the horizons of the dominant "masculine" jurisprudence and constitutional theory, ${ }^{29}$ she takes as her starting point the classical paradigm, according to which a human being "is naturally a citizen and most fully himself when living in a vivere civile."

Aristotle's statement that run counter to the traditional view, see SalKeVER, Finding the MeAN, supra note 20, at 72, 99-102, 170-74, 179-81, 202-03 (arguing that Aristotle sought to counter the extreme political view of human nature dominant in Greek society, to teach that political life is an end in itself, and to present a deliberative way of life as the supreme human good); Wayne H. Ambler, Aristotle's Understanding of the Naturalness of the City, 47 REv. PoL. 163, 169-72 \& n.13 (1985) (suggesting that Aristotle's assertion of the city's naturalness contains certain internal contradictions, reflects the political orientation of the Politics, and thus is not Aristotle's only word on the subject; and referring to Aristotle's statement in Nicomachean Ethics 1162al6-26 that man is by nature more a conjugal than a political animal).

27. See Michael J. Sandel, Introduction to Liberalism ANd 1Ts Critics 5-6 (Michael J. Sandel ed., 1984); Paul Brest, Constitutional Citizenship, 34 Clev. ST. L. Rev. 175, 188-89 (1986); Paul Brcst, Further Beyond the Republican Revival: Toward a Radical Republicanism, 97 YALE L.J. 1623, 1623-24 (1988); Sunstein, Beyond the Republican Revival, supra note 14, at 1547 n.37; see also Gardbaum, Law, Politics, and Community, supra note 14, at 690-92 (distinguishing thrce independent doctrincs associated with this idea). For a nonrepublican theorist who cites Aristotle's statcment about man's political nature approvingly, see Guyora Binder, What's Left?, 69 Tex. L. Rev. 1985, 1989 (1991) (linking radical political theory to the dictum and suggesting that "human nature [can] be reformed to realize the good society"). For criticism of the view that Aristotle's statement mcans that political life is superior to all other types of existence, see the arguments of Wayne Ambler and Stephen Salkever summarized supra note 26 and discussion infra Part V.B.

28. See supra note 14.

29. Sherry notes that the "feminine" perspective is not the province of females alone anymore than the "masculine" perspective is exclusively associated with males. Sherry, Civic Virtue, supra note 15, at 579.

30. Id. at 548 (quoting Pocock, Virtues, Rights, and Manners, supra note 13, at 355). Sherry, however, distinguishes her femimine vision from the Aristotelian paradigm in an important respect by rejecting Aristotle's concept of an abstract, transcendent human end. Id. at $547 \mathrm{n} .9,548-49$. She thus disagrees with Michelman, who rejects Aristotle's teleology altogether, and not just its transcendent aspect. See infra notes $43-45$ and accompanying text. Transcendent teleology assumcs both that human beings have a nature (end) and that this nature is universal and abstract. See Sherry, Civic Virtue, supra note 15, at 547-49. Sherry contrasts this notion with that of an immanent telos that is "defined in the context of the historically bound community that aspires to it." Id. at 548. 
Although she cites J.G.A. Pocock for this proposition, Pocock himself relies on the concept as elahorated by Aristotle in the Politics. ${ }^{31}$ According to Sherry, an integral part of the classical paradigm is that the very definition of a human being must be intersubjective, meaning that the essential attributes describing people's humanity are attributes of their lives as citizens, as "connected," or as "bits of society," and not attributes of their lives as solitary individuals. ${ }^{32}$ For Sherry, it is this aspect of the classical paradigin that led adherents of republicanism at the time of America's founding to endorse "citizen participation in a deliberative, value-selective form of government." 33

Michael Perry develops what he calls a "naturalist" or "neoAristotelian" understanding of morality. He presupposes that people "require society-and the artifacts of society, especially language and concepts-if they are to realize their distinctively human capacities, like speech and thought . . . ; indeed, their very identities, as individual persons, are achieved in and through relationships with one another."34 Perry calls the realization of our distinctively human capacity "flourishing," and he suggests that interpersonal relationships are constitutive of, and not merely instrumental to, flourishing. ${ }^{35}$

Cass Sunstein is probably the theorist most consistently associated with the contemporary republican revival. ${ }^{36}$ Although he enumerates political participation as one of the four central doctrines of his version of liberal republicanism, ${ }^{37}$ he adopts Aristotle's dictum in a qualified way. While noting that "[s]ome republican approaches are premised on the idea, traceable to Aristotle, that political life is the best life for human beings (or at

31. See J.G.A. Pocock, The Machiavellian Moment at vii, 66-80, 527, 550 (1975).

32. See Sherry, Civic Virtue, supra note 15, at 547-49; see also MichaEl J. SANDEL, Liberalism AND THE LIMITS OF JUSTICE 79-82, 143-44, 150-51 (1982) (discussing the intersubjective aspect of human nature); Gey, The Unfortunate Revival, supra note 16, at $822-33$ (discussing the civic republicans' view of the individual). On the distinction betwecn political and social interconnectedness for Aristotle, see infra note 76.

33. See Sherry, Civic Virtue, supra note 15 , at 552.

34. Michael J. Perry, Morality, Polmitcs, and Law: A Bicentennial Essay 11 (1988) [hereinafter Perry, Moraltry, Polmics, and Law].

35. See id. at 7, 11. For additional statements of political life as an essential part of human flourishing, see Benjamin R. Barber, Strong Democracy: Participatory Politics for a New Age at $\mathrm{XV}, 118-20$ (1984) [hereinafter BARBER, STRONG Democracy] (stating that "democracy is the condition of autonomy," and strong democracy is transformative, enabling people to develop their highest potential); SANDEx, LIBERALISM AND THE Limits of JUSTICE, supra note 32, at 149-54, 183 (elaborating a concept of community as constitutive of human identity, although not expressly adopting it in his own name, and asserting "the possibility that when politics goes well, we can know a good in common that we cannot know alone"); Donald W. Keim, Participation in Contemporary Democratic Theories, in Participation IN Polmics: Nomos XVI 1, 15-18 (J. Roland Pennock \& John W. Chapman eds., 1975) (describing two types of participatory democracy that aim at self-realization, one directed at self-realization of human potentialities and one directed at self-realization of citizenhood).

36. See supra note 14.

37. Sunstem, Beyond the Republican Revival, supra note 14, at 1541-42, 1555-56. 
least for certain classes of them),"38 Sunstein observes that "inodern republicanism respects other conceptions of the good life as well." 39 He concludes that citizen participation in political life, although intrinsically valuable, is not the only good life and that people's ability to control their representatives and to govern theinselves are additional benefits of political participation. ${ }^{40}$ Sunstein contrasts classical republicanism, which fosters civic virtue to improve the character of individuals, with modern republicanism, which "invoke[s] civic virtue primarily in order to promote deliberation in the service of social justice, not to elevate the character of the citizenry."41

Although Frank Michelinan is frequently identified as a contemporary republican theorist, ${ }^{42}$ his stance towards Aristotle's dictum about man's political nature is soinewhat equivocal. He notes that the belief in man's political nature is the foundation of a certain version of the classical republican paradigin, a version he ultimately rejects because it celebrates "public happiness." ${ }^{43}$ Michelman repudiates the ideal of public happiness because it assumes not only that participation in political life is a positive human good, but also that citizenship is an essential part of everyone's happiness. ${ }^{44}$ The latter doctrine, he finds, "runs against the modern liberal temper" and oppresses the mind and spirit because it forecloses human possibilities by assuming a single form of happiness exists for all human types. ${ }^{45}$

At the same time, Michelman's own vision of the good life presupposes the active exercise of practical reason, ${ }^{46}$ which is the chief cognitive political virtue for Aristotle. Although Michelman bases his vision on Immanuel Kant's view that "we are free only insofar as we are self-goverming, directing our actions in accordance with law-like reasons that we adopt for ourselves, as proper to ourselves, upon conscious, critical reflection on our identities (or natures) and social situations," he locates this

38. Id. at 1547 n.37 (citing to ARENDT, ON ReVolution, supra note 43, at 215-82).

39. Id.

40. Id. at 1569 .

41. Id. at $1550-51$.

42. See William W. Fisher III, Reconstructing the Fair Use Doctrine, 101 Harv. L. Rev. 1659, 1749 n.380 (1988) (noting Michelman's interest in classical republican ideology); Gardbaum, Law, Politics, and the Claims of Community, supra note 14, at $689-90$ (grouping Michelman with legal communitarians); Solum, Virtues and Voices, supra note 14, at 112 (classifying Michelman as one of the "architects of the republican revival"); sources cited supra note 14. Michelman views himself as a republican. See supra note 15.

43. Michelman, Traces of Self-Government, supra note 14, at 22. The phrase "public happiness" is not Aristotle's, but is used by Hannah Arendt. Hannah Arendt, On Revolutnon 115 (1963) (indicating that "public happiness" to eightecnth-century Americans meant the feeling that comes from "having a share in publie business," and they did not view such activities as a burden); see id. at 123-37 (describing a shift in Aunerican thought from public happiness to private happiness).

44. Michelman, Traces of Self-Government, supra note 14, at 22.

45. Id. at $22-23$.

46. Id. at 24 ("The path to understanding, I believe, lies ... through practical reason.") (footnote omitted). 
aspect of Kant's theory in the republican tradition. ${ }^{47}$ For Michelman, this means that freedom cannot be equated with "doing (and commanding) as one will"; rather, it entails "socially situated self-direction." As Association and deliberative dialogue, in turn, derive value from their role in facilitating the attainment of freedom and self-government, which are the ultimate ends. ${ }^{49}$ Michelman's conclusion is that genuine (which for hiin means nonteleological) republicanism subordinates the objectionable aspects of republican theory, such as civic virtue and a unitary common good, to the theory's "associational and conversational" values. ${ }^{50}$ This appears to reduce civic virtue to an instrumental, if essential, role in the human enterprise. Yet, to the extent Michelman believes that the ultimate objectives of human life (freedom and self-government) consist, in part, of public discourse among equals about the common good, ${ }^{51}$ there is a sense in which he too endorses pohtical participation as intrinsically valuable. ${ }^{52}$

47. Id. at 26-27 (referring to IMMANUEl Kant, GROUNDWORK Of the MEtaphysic of Morals 114 (H. Paton trans., Touchbook ed. 1984) and stating that "Kantianism implies republicanism"). Michelman also shows his reliance upon the republican tradition when he writes that the "linkage of citizenship with freedom has classical antecedents" and cites his discussion of Aristotelian republicanism based upon the premise of man's political nature. Id. at $37 \&$ n.180.

48. Id. at 75 .

49. Id. at $23-24,26-27$.

50. Id. at 23,38 .

51. Id. at 24,27 . Michelman's republicanism appears to accept the "positive-libertarian ideal of individual self-government through politics," as contrasted with the negative-libertarian politics of the Founders. Id. at 36-37. He identifies the positive-libertarian idcal largely with Pocock and Janics Harrington, whose theories developed out of what Michelman refers to as the nonteleological classical republican tradition. Id. at 36-47. Michelman emphatically asserts that Aristotelian teleology is coercive and oppressive, id. at 22, and he appears to reject the immanent teleology of Renaissance humanism as well, id. at 37-38. For Michelman, the Pocock-Harrington tradition of inclusive, participatory politics overcomes the defects of teleological republicanism. Id. at 38-47. Yet he also concedes that Harrington's republicanism involves a presupposed cognizable and objective common good. Id. at 40. Michelman dissociates this aspect of Harrington's republicanism from the common good im classical republicanism on the ground that the idea of an objective common good, "while crucial within the whole republican conception [given by Harrington], is not its underlying concern; selfgovernment is, and objective common good appears as a condition of self-government's possibility." Id. Thus, Harrington's republicanism is an improvement over classical republicanisn, although it still falls short of the type of republicanism Michelman envisions. Id. at 36 (referring to Harrington's views as a "fiawed exemplification of dialogic possibility").

52. The views of Robin West bear a strong resemblance to those of Michelman. Although West makes human nature the base line of her pragmatic theory of liberalism, she believes that human nature is subject to cbange or evolution, and thus that the good life is a dynamic concept. See West, Liberalism Rediscovered, supra note 15 , at $674,696-97$. As a consequence, hunan nature is not necessarily or permanently political. At the sane time, she also believes that knowledge of the good life at any time can be obtained only through a "shared enipirical imquiry," that is, a "cooperative, communitarian sbaring of hypothesis, method, and tentative conclusion." Id. at 695 (emphasis omitted). Her position resembles Michelman's in that human beings have a political nature that is partly instrumental to human happiness, but is also constitutive insofar as the public debate about the good life is itself part of the good life.

In an article discussing the views of Vaclav Havel, West appears to be at least as committed to individualism as Michelman. For West, the individual is the basic moral unit who must find his or her authentic self im truth rather than in communal activity or communal bonds. See West, Taking Freedom Seriously, supra note 1, at 63-71. At the sane time, West's emphasis on responsibility includes a strong 
Given the importance to republican-oriented theorists of participation in politics for a complete or fulfilled human life, it is surprising that republican theory often portrays the performance of civic duties as requiring sacrifice. ${ }^{53}$ Sherry, for example, says that "[r]epublicanism, unlike liberalism, exalts the good of the whole over the good of its individual members." She views the common good as both "distinct from and paramount to the good of individuals." 55 She also rejects self-love as a basis for political organization. ${ }^{56}$ The notion of sacrifice is epitomized by the concept of civic virtue, which is often explained as the willingness of citizens to put the interests of the political community ahead of their private interests. ${ }^{57}$

There is an internal contradiction in the works of contemporary writers insofar as they adopt both the idea of citizen sacrifice and the idea that man is by nature political. ${ }^{58}$ If human nature is political in the strong sense that people find liappiness, completion, or satisfaction, in whole or in part, througl participation in political life, then such participation in political life should entail not sacrifice, but its opposite. ${ }^{59}$ In other words, either civic

sense of a person's moral obligations to others and thus presupposes the "communitarian virtues of compassion, sympathy, fellow-feeling, and love." Id. at 66,72 . Because a sense of responsibility appears to be part of the authentic self, West's views overall appear to be less individualistic than those of Michelman.

53. See Sunstein, Beyond the Republican Revival, supra note 14, at 1547-48, 1564 (discussing sacrifice in classical republicanism); id. at 1550-51 (diseussing notions of sacrifice within contemporary republicanism); Sunstein, Interest Groups, supra note 14, at 31 \& n.10 (writing that the prerequisite to sound government is subordination of private interests and citing HERBERT J. StORINO, What the ANT1Federalists Werb For 19-23 (1981)); see also Daniel A. Farber \& PhILIP P. Frickey, Law and Public Choice: A CrItical Introduction 44 (1991) (stating that according to modern republican theory, citizens slrould "put aside their own interests and enter a public-spirited dialogue about the common good'); Geoffrey R. Stone et al., Constitutional Law 5 (2d ed. 1991); $c f$. Thomas L. Pangle, The Classical Challenge to the American Constitution, 66 CHI.-KENT L. REv. 145, 150 (1990) (maintaining that republicanism demands some measure of sacrifice from citizens of "what appears to be their private interest"). For a critical analysis of this issue, see Solum, Virtues and Voices, supra note 14 , at 114-22.

54. Sherry, Civic Virtue, supra note 15 , at 551.

55. Id. at 553 .

56. Id. at 548,553-54; see id. at 554 (" "Men must be ready, they must pride themselves, and be happy to sacrifice their private pleasures, passions and interests, nay, their private friendships and dearest connections, when they stand in competition with the rights of soeiety." ") (quotation from Letter from John Adams to Mercy Warren (Apr. 16, 1776), in The Selected Writinos of John and JohN Quincy Adams 57-58 (A. Kocli \& W. Peden eds., 1946)).

57. See, e.g., Sunstein, Interest Groups, supra note 14, at 31.

58. This contradiction has been noted by Lawrence Solum. See Soluun, Virtues and Voices, supra note 14, at 114 (observing that civic virtue theorists deny the authenticity of private interests, whereas the view that citizens should subordinate their private interests to the good of the community prcsupposes the integrity of those interests). Solum argues that commentators have confused moral virtue and moral continence (the latter being an Aristotelian term for acting in a moral fashion while desiring to act otherwise, whereas the former describes virtuous action coupled with virtuous desires). Id. at 116-17, 119-20; see also infra Part III.B (discussing weakness of the will (incontinence)). My resolution of the tension between self-interest and sacrifice is consistent with Solum's, but it follows a different path.

59. Based upon this reasoning, some have eriticized Aristotle for casting morality in fundamentally egoist or selfish terms, even though he also claims that the virtues are sought for their 
life demands sacrifice, suggesting that human nature is not political in important respects, or human nature is political in important respects, suggesting that civic life does not demand sacrifice. ${ }^{60}$ The concept of civic virtue thus captures the tension between the idea that political life is, in whole or in part, what fulfills human beings and the idea that political life requires foregoing personal fulfillment in the name of something more important.

\section{B. The Meaning of "Nature" in Aristotle's Statement that Human Beings Are by Nature Political}

This tension is partially eliminated if we examine Aristotle's statement about people's political nature in context. ${ }^{61}$ In popular usage, the expressions "by nature" or "natural" have the connotation of something that occurs spontaneously or automatically, something that does not need to be made or to be willed into existence. Understood this way, Aristotle's statement that cities (political commumities) exist by nature suggests that cities did not need to be "invented" because they arose in response to an innate human drive. Aristotle's further statement that humans are by nature political might mean that people seek to live in political communities and to participate in political life because of some deep or spontaneous impulse, without being instructed or coerced to so live and to thus participate.

In contrast to the term's popular usage, Aristotle uses "nature" in Politics 1.2 as a term of art. Early in the passage Aristotle states that "nature is an end: what each thing is ... when its coming into being is complete is, we assert, the nature of that thing."62 Aristotle equates a

own sake. For a discussion of Aristotle's morality in general and this contradiction in particular, see Brosnan, Virtue Ethics, supra note 18, at 345-49. For a parallel critique of Michael Perry's neoAristotelianism, see Richard H. Fallon, Jr., Of Speakable Ethics and Constitutional Law: A Review Essay, 56 U. ChI. L. Rev. 1523, 1529-31 (1989) (reviewing Perry, Moralrty, Polmics, and Law, supra note 34) (stating that the central deficiency of Perry's naturalism is "its egoisin, its assumption that an agent's concern with her own flourishing forms the appropriate center of moral thought"); see also Steven Shiffrin, Liberal Theory and the Need for Politics, 89 Mich. L. Rev. 1281, 1288-89 (1991) (book review) (describing Martha Nussbaum's Aristotelianisin as individualistic because of its emphasis on how to make individuals flourish).

60. There is a tension between the two ideas regardless of whether civic virtue is desirable for human fulfillment, see supra notes 29-33 (discussing Sherry); supra notes 34-35 (discussing Perry); for a good society, see supra notes $37-41$ (discussing Sunstein); or as a component of freedom and selfgovernment, see supra notes 43-52 (discussing Michelınan).

61. While the following text discusses "nature" in Aristotle's writings, it is equally important to recognize the significance of Aristotle's term "political." See infra note 76.

62. Aristorne, Polmics 1.2 1252b31-34 (Carnes Lord trans., 1984). Note that Aristotle uses "nature" differently in different places in his writings. For a general discussion of his use of the concept of nature, see K. von Fritz \& E. Kapp, The Development of Aristotle's Political Philosophy and the Concept of Nature, in 2 ARticles on ARISTOtLE: Ethics AND Polmics 113, 116-18 (Jonathan Barnes et al. eds., 1977); see also ARISTOTLE, PHYsics 2.1 (discussing various meanings of the term "nature"). Aristotle also appears to use the word in different ways even within Chapter 1 of the Politics. For example, Politics 1.2 begins by observing that we may best study things by looking at how they grow naturally (ta pragmata phyomena) froin the beginning, id. at $1252 \mathrm{a} 24$, and then he gives a genetic 
thing's end with its best state, the condition of something when it is selfsufficient. ${ }^{63}$ As a result, although Aristotle says it is evident that the city is one of the things that exist by nature, ${ }^{64}$ he also maintains that the person who first founded a city was the greatest of benefactors. ${ }^{65}$ This implies that cities or political communities exist by nature only in the sense that they perfect human existence; cities are not natural in the popular sense of the term.

The consequence of Aristotle's special use of the term "nature" in this passage is to establish a dichotomy between its popular usage and its use as a term of art. This dichotomy parallels the distinction between what a person possesses or pursues spontaneously, and the ideal or perfect condition that a person must first identify and then labor for affirmatively. To use modern vocabulary, the distinction is between nature as a descriptive concept and as a normative precept. ${ }^{66}$

account of the origin of the city out of the family and prepolitical associations, $i d$. at $1252 a 25 f f$. This use of the term "nature" parallels common usage. For other examples of "nature" in the Politics, see ARISTOTLE, PoLmincs 1.9 1257b10-11 (contrasting what exists by nature with what exists by convention); $i d$. at $7.131332 \mathrm{b3}-5$ (stating that other amimals live primarily by nature and, in some cases, by habit, whereas humans live by reason as well); $i d$. at $7.171337 \mathrm{a} 1-3$ (stating that education should observe the divisions in human life made by nature, such as the period between seven years old and puberty and the period between puberty and 21 years).

On Aristotle's use of the concept of nature in Chapter 1 of the Politics, see Ambler, Aristotle's Understanding of the Naturalness of the City, supra note 26, at 164-67. Ambler argues that Aristotle's claim that "every city exists by nature" is hypothetical: Aristotle ties the naturalness of the city to the naturalness of prepolitical associations, PoLmcs at $1252 \mathrm{bl}$, and then leaves the status of the latter ambiguous. Ambler, Aristotle's Understanding of the Naturalness of the City, supra note 26, at 164.

63. Arustorte, Polrics 1.2 1252b34-1253al; see id. at 1.2 1253a31-33 (stating that when a human being has attained his final end (telos), he is the best of animals).

64. Id. at $1.21253 \mathrm{a} 1-2$. Actually, Aristotle makes this claim about the city three times in Chapter 2. First he says that if prepolitical associations exist by nature, then the city formed from them exists by nature. Id. at 1.2 1252b30-31 (Lord and Jowett translations read "if," Barkcr's reads "because"). On a sccond occasion, Aristotle says it is "evident" (phaneron, a word often having the connotation of an appearance, i.e., what appears to be the case but may not really be thus) that the city is one of the things that exist by nature. Id. at 1253a1-2. Finally, toward the end of the chapter, Aristotle states that it is clear (dêlon) that the city is by nature and prior to the individual. Id. at 1.2 1253a25-26. Thus, Aristotle's argument in Chapter 1 of the Politics may show a progression from a conditional assertion about the naturalness of the city to a provisional assertion of its naturalness to an unambiguous assertion of its naturalness. But see Ambler, Aristotle's Understanding of the Naturalness of the City, supra note 26, at 164 (arguing that Book 1 of the Politics leaves the claim about a city's naturalness ambiguous); SALKeVer, FINDING THE MEAN, supra note 20, at 71 (revealing ambiguity in Aristotle's assertion about our pohtical nature); see also ARISTOTLE, NicomacheAN ETHICs 8.12 1162a16-19 (arguing that the friendship between a man and a woman (or husband and wife) aecords with nature since human beings are by nature more conjugal (sunduastikon) than political, inasmuch as the household is both prior in time and of greater necessity than the city).

65. Amstotle, Polmics 1.2 1253a30-31; see also Aristotle, De Motu Animalium 10703 a29b1 (comparing the natural disposition of the parts of animals to perform their respective functions to the operation of a city that has good laws, so that the members of the city perform their respective functions through habit).

66. See Cass R. Sunstein, Neutrality in Constitutional Law (with Special Reference to Pornography, Abortion, and Surrogacy), 92 Colum. L. REv. 1, 11-12 (1992) (writing that "nature was a normative notion" in classical philosophy and citing Aristotle's Physics). 
The dichotomy, in turn, appears to resolve the tension between the republican ideas of human nature as political and the importance of sacrifice in politics. A person's "nature," according to Aristotle's technical usage in the passage discussed, is not "natural" according to popular usage because it does not come into existence without active nurturing. Moreover, as persons labor affirmatively to attain their "Aristotelian" nature, they experience powerful, countervailing appetites and impulses that arise spontaneously at birth or as they grow up. In short, our natures are not "natural" in two distinct respects: we must labor toward our end or best state affirmatively, and we must labor against contending inpulses and appetites. ${ }^{67}$

Thus understood, the notion of sacrifice seems wholly appropriate. We are not born with an impulse to engage in political activity nor does the desire arise of its own accord. Rather we are "political" when we actualize our potential and achieve our best condition. ${ }^{68}$ While striving to develop our natures, we are continually beset by other needs and longings. These desires must be partially or wholly restrained if we are to labor successfully toward our ultimate goal. We may perceive sacrifice as our condition as we work toward that goal depending upon the power of our countervailing appetites and how well we appreciate the character and importance of our political objective. ${ }^{69}$

This interpretation of "nature" and "sacrifice" accords with another theme of republican-oriented political and legal theory: the distinction between "preferences" and "interests." "Preferences" is used commonly to describe people's desires and goals prior to refiection. Preferences may represent not ouly people's innate needs or desires but also their acquired feelings and opinions. At bottom, the term refers to people's mclinations toward and their understanding of what will promote their happiness prior to subjecting these things to critical examination as part of a public and deliberative process. ${ }^{70}$

67. This view does not prevent Aristotle from agreeing that people spontaneously seek to live with others in communities because for him merely living with others is very different fron interacting with them as citizens. See infra note 76.

68. On the concepts of potentiality and actuality in Aristotle, see ARISTOTLE, METAPHYSICs 5.7 1017a35-b9 (articulating the distinction between potentiality and actuality); id. at 5.12 ("capacity"); id. at 9 (discussing potentiality and actuality); ArIstotre, DE ANIMA 3.4 (discussing potentiality and actuality as applied to how thought occurs). Part V.B, infra, explores the possibility that Aristotle believed that the ultimate end of human life is not political, or not exclusively political.

69. For a different interpretation of this tension in Aristotle's statenuents about our political nature, see SALKEVER, Finding the MEAN, supra note 20, at 72-74 (rejeeting both the interpretation that Aristotle views political life as an ethical idcal and that he views political life as a biological neeessity).

70. West, Liberalism Rediscovered, supra note 15, at 718-19 (describing the view of John Stuart Mill that what we prefer "as opposed to that which will make us truly happy, is determined by what an individual knows and has been taught to desire-it is a function, in short, of our contingent nature rather than of our essential nature"); PERRY, MORALTTY, POLTICS, AND LAw, supra note 34, at 20, 80 (equating preferences with wants, desires, and sensibilities that people have prior to reflection). 
In contrast, "interests" is used commonly to refer to things people consider important as a result of deliberative inquiry or, in the case of some theorists, public deliberative inquiry. ${ }^{71}$ Our interests, in other words, may be different from, and even at war with, our preferences.

Based upon this distinction, several republican-oriented theorists reject the validity of using people's preferences as a normative criterion for judging the value of individual or political choices. They reason that preferences may be inappropriate standards for action if they are products of such things as biology, inaccurate appraisals of available possibilities, or a socialization process that assumes the legitimacy of the existing, and often questionable, status quo. ${ }^{72}$ As a consequence, these theorists believe interests should provide guidance for and be the measure of public policy and decisionmaking. ${ }^{73}$ In the words of Michael Perry, if a person takes the pref-

71. See, e.g., Perry, MoraltTy, Polmics, ANd Law, supra note 34, at 19-20, 46-47, 80 (linking a person's interests to her real happiness or flourishing, in contrast to her prefcrences, which may be mistaken and undermine her happiness). The distinction between preferences and interests made by republican-oriented theorists discussed in this paper is different from the distinction made by others between short-term desires and long-term plans or projects. See, e.g., LoREN E. Lomasky, Persons, RIGHTS, AND THE MORAL COMMUNITY 25-27 (1987) (writing that because projects are not rcducible to "various episodes of desire satisfaction," they are constitutive of personal identity, whereas intermittcnt or fleeting desires are not); see also Cass R. Sunstein, Legal Interference with Private Preferences, 53 U. CHr. L. REv. 1129, 1140 (1986) (distinguishing second-order preferences which are preferences about preferences, from first-order preferences, which are direct and often short-term desires for particular objects).

72. See, e.g., Perry, Moraltry, Poltitcs, and LaW, supra note 34, at 80-81; Sunstein, Beyond the Republican Revival, supra note 14, at 1543-44 (suggesting that some preferences are the product of "unjust background institutions" or "derive from various distortions, including the phenomenon of adaptive preferences on the part of victinn"); Sunstein, Legal Interference with Private Preferences, supra note 71, at 1133 (stating that beeause private preferences may be mere social constructs shaped by circumstances, they are not necessarily autonomous); see also Michelman, Traces of Self-Govermment, supra note 14, at 27 (asserting that "[a]ny view in which the true, primary interests of individuals are 'exogenous' or prior to politics is unrepublican").

73. See Perry, Moraltit, Polmics, ANd LAw, supra note 34, at 79-81 (criticizing two forms of utilitarianism because they take people's unexamined sensibilities and preferences as the base line); id. at 151-52 (stating that where politics takes preferences as the base line, it is manipulative and smallish; politics should be deliberative and transformative, challenging our existing preferences through public and rational discourse); Sunstein, Administrative Substance, supra note 15, at 613 (arguing that liberal republicanism should strive to accommodate the views deeided upon through conversation and debate); Sunstein, Beyond the Republican Revival, supra note 14, at 1548-49 (discussing the need for deliberation in politics and the role of preferences in that deliberation); Sunstein, Interest Groups, supra note 14, at 31-32 (noting that for the republicans at the time of the Founding, preferences were not "exogenous, but to be developed and shaped through politics," especially public discussion); id. at 46 (quoting THE FEDERALIST No. 71 (Alexander Hamliton) to the effect that our representatives should be "guardians" of the people's interests when their interests "are at variance with their inclinations"); Sunstein, Legal Interference with Private Preferences, supra note 71, at 1131-38 (arguing that the legal system should not take private preferences as exogenous variables when they are not autonomous and should use regulation to promote greater deliberation about ends); Cass R. Sunstein, Naked Preferences and the Constitution, 84 CoLum. L. Rev. 1689, 1690-92 (1984) (arguing that the Constitution prohibits Congress from legislating to further private interests instead of the public interest); Cass $R$. Sunstein, Political Self-Interest in Constitutional Law, in BEYOND SELF-INTEREST 209, 210-13 (Jane J. Mansbridge ed., 1990) (arguing that judge-nnade public law tends to reject pluralist politics and to disfavor legislators from taking action solely in response to raw political power, although this tendency 
erence-interest dichotomy to its logical conclusion, she has an interest in (among other things) the "nonsatisfaction of preferences the satisfaction of which is antithetical to her flourishing."

To translate this insight of republican theory from the classical naturebased vocabulary to the modern interest-based vocabulary, certain contemporary repubhican theorists adopt the view that participation in political hife is one of our core or constituent interests, and perhaps the inost important interest. However, in the process of seeking and realizing that interest, a person inay have to overcoine some or many unexamined or felt preferences. Thus, there is no inconsistency between the two strands of republican thought noted above because, on the deepest level, no tension exists between one's properly understood private interest and the public interest. To the extent that civic virtue requires us to sacrifice our own good for the good of the whole, it does so only while we misconceive our personal good while our preferences are unexamined. "Sacrifice" may be necessary for the initial attainment of civic virtue, but not for its ultimate exercise. ${ }^{75}$

\section{The Theoretical Basis for Aristotle's Statement that Human Beings Are by Nature Political}

Before turning to the consequences of equating human nature with human perfection, it will be useful to examine how Aristotle arrives at his conclusion that human nature is political. ${ }^{76}$ Ultimately his thesis about

is only weakly enforced); West, Liberalism Rediscovered, supra note 15, at 682 (asserting that pragmatic liberalism entails equal respect, and thus, majority preferences should be overridden when "[i]ntelligent, historically bound, and sensitive discrimination" of such preferences so determines); see also West, Taking Preferences Seriously, supra note 1, 664-65, 669-700 (arguing that a judge should be paternalistie in contract and constitutional litigation based upon a "sympathetic [not idealistic] understanding of the subjective well-being, aspirations, goals, values, and plights of the litigants before her").

74. Perry, MoraltTy, Politics, and Law, supra note 34, at 80 . For an extended criticism of this republican idea, see Gey, The Unfortunate Revival, supra note 16, at 822-32. There is a similarity between the modern preference and interest distinction and Aristotle's distinction between praiseworthy self-love and blameworthy self-imterest (or selfishness). See Aristotle, Nicomachean Ethics 9.8 (stating that praiseworthy self-love consists of gratifying one's higher self while suppressing one's lower self; blameworthy selfishness consists of gratifying one's lower self at the expense of one's higher self).

75. There may be instances where a person's preferences, innate or acquired, coincide with her interests. To the extent that the contemporary republican notion of interests demands a reflective as well as a substantively correct understanding of one's interests, such a coincidence would be superficial. Accordingly, it is not enough to seek a good way of life; one must seek it for the right reasons.

76. The adjective "political" comes from polis, the Greek word for city. Aristotle views a city as a unique type of association. A city differs from subpolitical or prepolitical forms of association because the purpose of its inhabitants is living well (to $\mathrm{eu} z \mathrm{n}$ ), whereas the other associations have less important or less comprchensive objectives, such as survival and material comforts. See ArIstotze, PoLrtics $1.21252 \mathrm{~b} 29-30$ (concluding that the city coines into existence initially for the sake of living, but it remains in existence for the sake of living well); id. at $3.91280 \mathrm{~b} 38-1281$ a10 (contrasting the choice to live together, which is the aim of subpolitical associations, with the choice to live well, act nobly, and acquire political virtue, which are the goals of a political community); id. at $3.51280 \mathrm{~b} 7-31$ (writing that what is truly a "city," not just a city in name only, inust pay attention to virtue; for a "city" is not just an association of people in one place for the sake of security and inaterial advantages). 
human nature cannot rest solely on empirical grounds because it depends upon an understanding of human nature in its best state. ${ }^{77}$ If human nature truly aspires to a best state, one it rarely attains or has not completely attained to date, ${ }^{78}$ then by limiting our understanding of human nature to historical precedents, we would be depriving ourselves of the opportumity to identify mankind's best state. As a consequence, Aristotle does not base knowledge of human nature and human happiness solely upon personal observations, even as enriched by the observations of others-although that

For Aristotle, the distinguishing factor between cities and other associations is thus not quantitative but qualitative. The difference is the specific end that each form of association pursucs. The ability to recognize the good life and to make it the end of political association belongs to human beings exclusively because only humans possess reason and speech, making it possible to distinguish between good and evil, just and unjust. Id. at 1.2 1253a7-18. On the relationship between political association and other types of human association, see Catherine H. Zuckert, Aristotle on the Limits and Satisfactions of Political Life, 11 InIERPRETATION 185, 187-96 (1983). Some contemporary legal theorists have recognized the special meaning that Aristotle attributes to the tenn "political." See, e.g., Buchanan, Assessing the Communitarian Critique of Liberalism, supra note 16, at 859 (distinguishing the "allinclusive political community" froin less comprehensive forms of community); Ronald R. Garet, Communality and Existence: The Rights of Groups, 56 S. CAL. L. REv. 1001, 1070 n.173 (1983) (observing that Aristotle believed that humans are "polis-dwelling," and are not merely gregarious as other animals); David Schuman, Beyond the Waste Land: Law Practice in the 1990s, 42 HAstinos L.J. 1, 7 (1990) (arguing that Aristotle's dictum that humans are naturally community-dwelling means more than the proposition that people live together to aggregate their interests; rather, community is the instrument of fulfillment). Many commentators, however, have assumed that Aristotlc's statement means that people are naturally "social" in the sense of being drawn to associate with others, although not necessarily in a political forum. See, e.g., Mark TushNET, RED, Whitr, AND Blue 10 (1988) (Inaintaining that the republican tradition "msisted that people are social beings who draw their understandings of themselves and the meaning of their lives from their participation with others in a social world that they actively and jointly create"); Anthony T. Kronman, Living in the Law, $54 \mathrm{U}$. CH. L. REv. 835, 859-60 (1987) (arguing that "pohtics" consists of seeing to the well-being of a community by making it a harmonious whole, regardless of whether the community is a university, foundation, corporation, or political eommumity in the traditional sense); Fred Dallmayr, Nature and Community: Comments on Michael Perry, 63 Tur. L. Rev. 1405, 1416 (1989) (book review) (reviewing Perry's stance that huinans are social in the sense that they require society).

My criticism of the tendency to equate "social" and "political" would not apply to the term "social" when used in a comprehensive inanner such as in the phrase "social science." See SaLKEver, Findino THE MEAN, supra note 20, at 59 (observing that the modern use of the term social science, which includes the disciplimes of political science, anthropology, sociology, psychology, economics, and history, appears analogous to Aristotle's "political science" as the term is used in the Politics and the Nicomachean Ethics).

77. In contrast to Aristotle, Robin West's pragmatic liberalism discovcrs the best state for human beings exclusively by scrutinizing history, tradition, and experience to identify what has made people happy in the past. West, Liberalism Rediscovered, supra note 15, at 680-83. However, it is unclear from West's account what enables us to identify happiness in the past. West would not assume a congruence between felt preferences and happiness, since this equates preferences with interests. 1d. at 682. She speaks of a rational inquiry into what people learn from experience, but docs not offer any guidelines or criteria to evaluate the raw data supplied by history, tradition, and experience. Ultimately, she believes that the present day community itself identifics the good life through shared cooperative inquiry. Id. at 696; cf. id. at 690 (noting that Mill believes "the relevant community of competent judges" should make such determinations). Left unclear is the basis upon which the community will resolve mevitable disagreenents in identifying past happiness.

78. This is especially true if Aristotle believes that contemplation is the essence of human perfeetion. See infra Part V.B. 
is surely one aspect of Aristotle's method, and the dominant one at the outset of his inquiries. Ultimately, however, his understanding of human nature and, thus, of human nature as political derives from his understanding of the human soul.

Aristotle elaborates his view of the soul in the Nicomachean Ethics, relying, in part, on conceptions developed and insights reached in his works on natural philosophy, especially the philosophical study of soul and mind. ${ }^{79}$ For Aristotle, the human soul is comprised of distinct but interacting faculties, the most important being reason, imagmation, appetite (or desire), and sense-perception. ${ }^{80}$ Reason, in turn, has two aspects: theoretical reason, referred to as speculation, and practical reason, referred to as prudence or practical wisdom. ${ }^{81}$ Happmess, which is Aristotle's term for describing the condition of people who have achieved their best state, cannot occur uuless the soul is in its best state. This requires that the various faculties of the soul, or the most important of them, are as virtuous or excellent as possible. ${ }^{82}$

79. See Cooper, Reason and Human Good in Aristotre, supra note 12, at 175-78 (describing the reliance of the intellectualist portrait of happiness on Aristotle's theory of the human soul elaborated in De Anima); W.F.R. HARDIE, ARISTOTLE's ETHICAL THEORY 39-40 (2d ed. 1980) (asserting that Aristotle's discussion of happiness in the Nicomachean Ethics is based, in part, on an account of the soul similar to the account in De Anima); IRWIN, ARISTOTLE's First PRINCIPLES, supra note 19, at 27980 (asserting that Aristotle's ethical argument is based upon his first philosophy, elaborated in the Metaphysics, and his science of the soul, elaborated in De Anima); T.H. Irwin, The Metaphysical and Psychological Basis of Aristotle's Ethics, in Essays on ArIstotue's Ethics 35, 36-37 (Amelie O. Rorty ed., 1980) (arguing that Aristotle's account of human happiness in the Nicomachean Ethics depends in part upon his theory of the soul, as developed in the De Anima, and his theory of substance, form, and matter, as elaborated in the Metaphysics). But see Tinothy D. Roche, On the Alleged Metaphysical Foundation of Aristotle's Ethics, 8 ANCIENT PHIL. 49 (1988) (arguing that Aristotle does not have recourse in the Nicomachean Ethics to principles derived in psychology or metaphysics; rather his method in the Nicomachean Ethics is dialectical, and he presents ethics as an autonomous science); cf. Monan, Moral KNowledge and Its Methodology IN ARISTotle, supra note 12, at 111-12 (concluding that there are two strands in Aristotle's Nicomachean Ethics, one relying on value language as a "rational ultimate" (instead of on metaphysical primciples) and the other borrowing its principles from a speculatively conceived psychology of man).

80. See Aristotle, De ANima 2.3 (providing a preliminary discussion of the elements of the soul). Aristotle's systematic treatment of soul and mind is contained in De Anima (discussing the nature and faculties of the soul, human and nonhuman, rational and nonrational). However, a complete picture of Aristotle's philosophical psychology can only be gathered by reference to the discussion of these topics in Aristotle's other works-especially the Nicomachean Ethics, Eudemian Ethics, Politics, and Rhetoric. See also infra notes $81,82$.

81. See ARIstotze, DE ANIMA 3.10 433al4-15 (distinguishing the practical, calculative mind from the theoretical mind); ARISTOTLE, NICOMACHEAN Ethics 1.13 1102a26-28 (dividing the soul into the rational and irrational); id. at 6.1 1139a6-15 (positing that the rational soul can be divided into the scientific element and the calculative or deliberative element); ARISTOTLE, Pourtics 7.14 1333a16-30 (dividing the soul into the element possessing reason and the element able to obey reason, and subdividing the rational element into the practical and the theoretical).

82. As observed by Irwin:

The doctrine of the soul as the form of the living organism explains Aristotle's conclusion that happiness will be a realization of the soul; he does not exclude the body from consideration but simply insists that happiness will involve the hiving being in its functional rather than its purely structural and material aspects. 
The doctrine that people can be identified with their souls, or what is highest in them, ${ }^{83}$ underlies Aristotle's accounts of human nature. In particular, Aristotle observes that while inany animals are gregarious, human beings are more political than other animals because they have logos (reason or speech), which enables them to distinguish the useful and the harmful, the just and the unjust, and good and evil. ${ }^{84}$ This observation not only highlights the distinction Aristotle makes between the social and the political, ${ }^{85}$ it also emphasizes the link he draws between political and rational life. In those passages of his works asserting people's pohtical nature, it is the character and ordering of the soul's parts that provide the criteria in light of which Aristotle examines and evaluates the various opinions and empirical evidence about human happiness.

Based upon the preceding, the statement that people are by nature political animals should inean that people are in their best state when they have acquired the virtues or excellences associated with political life, i.e., the moral virtues and the most excellent state of practical reason. This conclusion is problematic because it suggests that theoretical reason is some-

Irwin, The Metaphysical and Psychological Basis of Aristotle's Ethics, supra note 79, at 48-49. For Aristotle, a living organism's soul is its form, essence, and function. See id. at 48. Although the soul includes the faculties that cause nutrition and growth, these are not anong the faculties that distinguish human beings from other living organisms, and it is not part of human excellence. ARISTOTLE, Nicomachean Etrics 1.13 1102a32-b12. Thus, when Aristotle talks about the human soul in its best state, the nonhuinan faculties are not mentioned. See ARISTOTLE, Eudemian EtHics 2.1 1219b37$1220 \mathrm{a} 2$ (stating that his discussion of the soul will omit the vegetative part and the part associated with growth because they are not specific to the human soul). Animals, as well as human beings, have appetites; yet Aristotle discusses the appetitive faculty in discussing the best state of the human soul because it can be govemed or directed by the rational faculty, which is distinctly human. Id.

83. See ARISTOtLe, Nicomachean Etrucs 10.7 1177a12-13 (arguing that if happiness consists of activity in accordance with virtue, it is reasonable that it consists of activity in accordance with the supreme (kratist $\bar{e}$ ) virtue); id. at $10.61176 \mathrm{~b} 9-35,1177 \mathrm{a} 6-10$ (arguing that happiness does not seem to consist of bodily pleasures and amusements). This implies that Aristotle identifics human beings exclusively with their souls, or the highest faculties of their souls, and not with the total human organism. Id. at $9.81168 \mathrm{~b} 31-1169 \mathrm{a} 3$ (asserting that the person who loves himself in the admirable sense of self-love will always obey the most authoritative (kuriotaton) part of himsclf and that each person is identified with his intelligence). On the last passage and the identification of happiness with the most supreme virtue, see COOPER, Reason and Human Good IN ARISTOTLE, supra note 12, at 15663 (noting that by equating the idea of self exclusively with mind or intellect, Aristotle is challenging the view that a person's physical and emotional capacities are part of one's self). Howevcr, another commentator asserts that, in the passage at Nicomachean Ethics $9.81168 \mathrm{a} 28-1169 \mathrm{a}$, Aristotle is presenting a generally accepted opinion, not his own views. JOHN BURNET, THE ETHICS OF ARISTOTLB 422-23 (1900). Burnet notes that when Aristotle asserts the view "more positively" at $1169 \mathrm{a} 2-3$, he adds the qualification that a person can be identified with his rational self "most of all." Id. at 423. This qualification suggests that Aristotle's own view is not as extreme as the first view he diseusses. For a similar interpretation of "most of all," see Nancy Sherman, The Fabric of Character: Aristotle's Theory of VIRTUE 101 (1989) [hereinafter Sherman, Fabric of Character]. For the various meanings of "the most authoritative" in the Nicomachean Ethics, see GrANT, ThE Ethics of ARISTOTLE, supra note 12, at 425 (note to Nicomachean Ethics 1.2 1094a26).

84. Aristotle, Polmics 1.2 1253a9-18. For a discussion of this passage, see SAlKever, Findino THE MEAN, supra note 20, at 74-76; Steven B. Smith, Goodness, Nobility and Virtue in Aristotle's Political Science, 19 PoLrTy 5, 15-16 (1986).

85. See supra note 76. 
how of a lower order than practical reason. ${ }^{86} \mathrm{~A}$ parallel tension occurs between Aristotle's portrait of human nature as fundamentally political and his contrasting portrait of human nature as fundamentally contemplative. ${ }^{87}$ Regardless of how these interpretative difficulties are resolved, in the final analysis it is the concept of the soul that furnishes Aristotle with a standard for judging tradition, history, and experience. It is also a standard that most contemporary republican theorists reject in favor of some form of commumity consensus or shared values. ${ }^{88}$

\section{Consequences of Aristotle's Interpretation of the Political Nature of Human Beings}

If people are political by nature in the Aristotelian sense of needing engagement in political life to fulfill their humanity, but they are not impelled spontaneously toward this goal by an innate longing, what are the consequences for legal theory? First and foremost, it is necessary to under-

86. Not only does Aristotle never rank the parts of the soul this way; in several places he explicitly ranks theoretical reason above practical reason. See AristorLE, NicomachEAN ETHICs 6.121143 b3435 (stating that it would be strange if practical wisdom, which is inferior to wisdom, nonetheless was more authoritative than wisdom); id. at 6.13 1145a6-7 (asserting that practical wisdom does not control wisdom, nor the better part of the soul); id. at $10.71177 \mathrm{a} 12-18$ (assuming that happiness is activity in accordance with what is best in us, the activity of complete happiness is theoretical); ARISTOTLE, MaGNa Moralia 1.34 1197b4-10 (implying that philosophy, which is the excellence of the part of the soul devoted to unchanging objects, is superior to wisdoun, which has human things as its object). On the other hand, according to John Cooper, in three of the four passages where Aristotle presents his "identity thesis," i.e., the view that a human being should be identified with the person's mind, Aristotle identifies humans with "undifferentiated mind regarded principally from the practical side, or else with the practical intellect itsclf." COOPER, REASON AND HuMAN GOOD IN ARISTOTLE, supra note 12, at 16873 (discussing Nicomachean Ethics 9.4 and 9.8 and a passage in the Proptrepticus). Richard Kraut also intcrprets the reference to "mind" in Nicomachean Ethics 9.8 as referring to practical reason. RiCHARD KRAUT, ARISTOTLE ON THE HuMAN GOOD 128 (1989) (arguing that "mind" at Nicomachean Ethics $1168 \mathrm{~b} 35$ refers to practical reason because the text in 9.8 identifies mind with "the part of the soul that enables soineone to deliberate and inake choices"); see also SHERMAN, FABRIC OF CHARACTER, supra note 83, at 100-01 (interpreting the passages in 9.8 as referring to a combination of practical and theoretical reason). But see C.D.C. ReEve, Practices of Reason: ARISTOTLE's NicomaChean ETHICS 134 (1992) (rejecting the interpretation of mind as practical reason in this passage). If, in fact, Aristotle identifies humans more often with practical reason than theoretical reason, this might suggest that practical reason is somehow supreme. As a consequence, human nature would be political first and foremost. Aristotle comes closest to this view in Book 6.13, when stating that practical wisdom is responsible for the coming into being of thcoretical reason and all other virtues. ARISTOTLE, Nicomachean Ethics 6.13 1145a8-9. However, he also states that this does not mean that practical wisdom is in control of theoretical wisdom. Id. at 6.13 1145a6-7, 9.

87. See infra Part V.B.

88. See infra notes $99-100$ (noting the reservations of conteinporary legal theorists about the political relevance of universal or transcendent rules). Aristotle distinguishes between those aspects of human affairs that are universal and unchanging and those that are contextual and evolving. In connection with the latter, his analysis of how we attain understanding of human matters resembles contemporary legal theory. Aristotle may differ froin these theorists, however, in believing that universal theoretical insights inform practical reason even if they do not dictate to it. See ArISTOTLE, NicOMACHEAN ETHCs 10.9 1180a32-1181b22 (implying that political science, the science of the law, and the philosophy of human affairs are useful for discovering how to live well and how government should be organized). 
stand how, as a practical matter, human nature can be sought and attained. In particular, it is necessary to explain how people will arrive at an understanding of the content or attributes of human nature. Once human nature is understood, it is necessary to describe what will motivate people to undertake the arduous task of overcoming their innate and powerful impulse to satisfy spontaneous appetites and cater to unexamined preferences.

Further, and equally troubling, if knowledge of the attributes of human nature or happiness is itself inaccessible without sustained and focused imvestigation, what will motivate people to undertake this investigation in the first place? After all, both Aristotle and contemporary theorists agree that most people think they already know what makes them happy and they probably equate their preferences with their interests.

The attainment of happiness thus presupposes two phases of what might be called sacrifice: first, the willingness to restrain one's spontaneous appetites and preferences in order to seek and acquire a vision of the good life; second, the willingness to restrain one's spontaneous appetites and preferences to implement that vision. Legal theory, then, must address the motivation for self-restraint as much as it addresses the cognitive means of ascertaining and promoting a vision of the good life. To date contemporary legal theorists have not appreciated Aristotle's insight that human nature is an object of striving against formidable odds. This has resulted in their failure to address effectively the motivational obstacles to realizing a more deliberative and participatory democracy.

\section{II \\ Realizing Our Political Nature: The Approach of CONTEMPORARY REPUBLICAN-ORIENTED LEGAL THEORY}

If you were to ask people to describe their true or authentic selves, most would talk about the opinions and feelings they possessed when you posed the question. Intuitively, most people would not respond favorably to the distinction prevalent in contemporary legal theory between mere preferences and genuine interests ${ }^{89}$ nor to the proposition that political activity and a commitment to the common good affords greater satisfaction than many, if not most, private activities. This Part examines the way contemporary legal theorists address this issue and the related motivational problenis discussed above.

89. See supra Part I.B (discussing the distinction between preferences and interests). 


\section{A. Dialogue and the Scrutiny of Unexamined Opinion}

Most contemporary legal theorists addressing republican concerns advocate some form of deliberative democracy. ${ }^{90}$ The heart of their recommendations for making political life more deliberative is the establishment of certain procedures in the decisionmaking process designed to enhance, if not ensure, a rational or reasoned basis for legislative, judicial, and other political determinations. ${ }^{91}$ For example, Cass Sunstein, who offers some of the most concrete and detailed proposals, recommends reforming the legislative process to include safeguards analogous to those currently employed under the administrative law rubric of the "liard look" doctrine. These proposals include requiring agencies to give detailed explanations for their actions, justify departures from previous practices, allow participation by affected groups, identify reasonable alternatives to the course of action finally adopted, and give reasons why the alternatives were rejected. ${ }^{92}$

To enforce such requirements in the legislative sphere, Sunstein recommends that the Supreme Court strike down laws enacted through the raw exercise of political power. ${ }^{93}$ He points out that courts currently enforce a rationality standard when evaluating legislation against a constitutional challenge. ${ }^{94}$ This standard is not only less rigorous than the hard look doctrine, it is ineffective: it is enforced only intermittently, and the courts are willing to hypothesize a reasoned justification for a challenged statute even though none exists in the legislative history. ${ }^{95}$ Sunstein concludes that if rationality review were strengthened and vigorously enforced, the incentive

90. See, e.g., Perry, Morality, Polmtics, ANd LAw, supra note 34, at 4, 103-04, 127-78 (discussing his theory of a deliberative, transformative politics); supra text accompanying notes 49-51 (Michelman's views), notes 37-41 (Sunstein's views). Examples of theorists who do not extol deliberative democracy are Michael A. Fitts, Look Before You Leap: Some Cautionary Notes on Civic Republicanism, 97 YALE L.J. 1651 (1988) [hereinafter Fitts, Look Before You Leap]; Michael A. Fitts, The Vices of Virtue: A Political Party Perspective on Civic Virtue Reforms of the Legislative Process, 136 U. PA. L. REv. 1567 (1988) [heremafter Fitts, The Vices of Virtue]; Gey, The Unfortunate Revival, supra note 16; Don Herzog, Some Questions for Republicans, 14 POL. THEORY 473 (1986); Lanry G. Sinon, The New Republicanism: Generosity of Spirit in Search of Something to Say, 29 WM. \& MARY L. Rev. 83 (1987).

91. See Michelman, Traces of Self-Government, supra note 14, at 25-26, 31 (arguing that freedom requires that people act based upon their own considered reasoning); Sunstein, Interest Groups, supra note 14 , at $57-58$ (observing that the reasoned analysis requirement, which is "classically republican," makes the process primary and the outcome secondary).

92. Sunstein, Interest Groups, supra note 14, at 60-61. For Sunstein's proposals based upon the hard look doctrine, see $i d$ at 69-75.

93. Id. at 69; $c f$. Jonathan R. Macey, Promoting Public-Regarding Legislation Through Statutory Interpretation: An Interest Group Model, 86 CoLum. L. Rev. 223, 240-56 (1986) (arguing that the Court should interpret statutes as though they were public-regarding unless a statute's legislative history explicitly reveals that it resulted from an interest-group deal; this presumption will deter special interest legislation by increasing its costs to the sponsors).

94. Sunstein, Interest Groups, supra note 14, at 53-54.

95. Id. at 49-55; see also Fitts, The Vices of Virtue, supra note 90, at 1590-91 \& n.70 (noting how infrequently the Court makes deliberation by the legislature a factor in its determination of the constitutionality of statutes challenged as racially discriminatory). 
for a more deliberative legislative process would be significantly increased. $^{96}$

Although proposals for more deliberative decisionmaking emphasize procedure, the objective, in significant part, is to improve outcomes. Theorists occasionally phrase this objective in terms of achieving substantively correct outcomes. ${ }^{97}$ More often, the goal is portrayed as reaching outcomes that are best for a particular community. ${ }^{98}$ Theorists advocating

96. Sunstein, Interest Groups, supra note 14, at 69.

97. See Sunstein, Administrative Substance, supra note 15, at 613 (observing that "right answers to political controversy" can often be discerned); Sunstein, Beyond the Republican Revival, supra note 14, at 1554 ("The process . . . is designed to produce substantively correct outcomes."); Sunstein, Interest Groups, supra note 14, at 42 (referring to "something like an objective public good"). Note, however, that in Beyond the Republican Revival, supra note 14, at $1550 \mathrm{n.53}$, Sunstein says that it is beyond the scope of the article to resolve "[w]hether and to what extent these outcomes are culturally specifie" rather than truly independent of particular settings. Then, in a subsequent note, he says that the process of arriving at a concept of the common good in a deliberative decisionmaking structure "[o]f course . . occurs within cultural limits." Id. at 1554 n.77. This statement may mean that whenever Sunstein speaks of correct outcomes, he has in mind correctness relative to particular cultures. See Sunstem, Administrative Substance, supra note 15, at 613 (the criterion for determining whether right answers have becn reached is consensus, i.e., the agreement of the citizens); Gey, The Unfortunate Revival, supra note 16, at 809-10 (arguing that it is inconsistent for contemporary civic republicans to claim that civic virtue and the good have some defining characteristics and, at the same time, to emphasize self-rule as a major goal of political participation); Paul W. Kahn, Community in Contemporary Constitutional Theory, 99 Y ALE L.J. 1, 40-42 (1989) (discussing the ambiguity in Sunstem's work); Kahn, Reason and Will, supra note 23, at 473 (observing that the Founders' attempt to synthesize reason and will, or political truth and political legitimacy, "was not only fragile politically; it was fragile theoretically"). Amy Gutmann, Democratic Education 95-97 (1987) (positing that deliberative processes should be used to decide educational policy even when the outcomes are incorreet, assuming they do not violate basic democratic norms like nondiscrimination and nonrepression, since self-government is an end in itself).

98. See Perry, Moraltry, Polmtics, ANd Law, supra note 34, at 40 ("the truth (or falsity) of any belief is always relative to a web of beliefs"; thus, a belief can be true relative to one community's basic beliefs while being false relative to another community's basic beliefs); id. at 50-51 (asserting that it is possible to distmguish better and worse conceptions of the good using the shared beliefs of a particular community as the standard); Sherry, Civic Virtue, supra note 15, at 587-89 (taking the view that the feminine perspective gravitates toward concrete universals that evolve because they are located in history and society, as contrasted to abstract universals, which are fixed); id. at 548 (according to Sherry's idealized classical paradigm, the community shapes and chooses its own values by "an artistic or creative weaving of rational thought, intuition, and tradition," and not by mediation or abstract philosophizing). See generally BARBER, Strong Democracy, supra note 35, at xii ("Democratic politics is a form of human relations, and does not answer to the requirements of truth."); id. at 163-72 (elaborating a theory of political and moral knowledge that is based upon experience and creativity, and that is neither subjective nor based upon deductive reasoning).

Brnce Ackerman also appears to belong to those theorists for whom moral and political truths are relative to particular communities. 1 ACKERMAN, WE THE PEOPLE, supra note 15, at 14-15 (observing that, as a matter of constitutional law, the citizens of the United States could legitinately pass an amendment abolishing freedom of religion and designating the United States a Christian nation). However, he also approves the current German constitution that makes certain rights permanent by removing them from the amendment process and he professes a preference for some degree of entrenchment in the United States Constitution as well. Id. at 319-21. The contrast between these positions suggests a larger tension in Ackerman's work. See Miriam Galston \& William A. Galston, Reason, Consent, and the U.S. Constitution: Bruce Ackerman's Wo the People, 104 Etwics 446, 449, 463-66 (forthcoming 1994) (arguing that there is a fundamental contradiction in Ackerman's theory between the place of reason and the place of will or consent); Kahn, Community in Contemporary 
deliberative democracy have developed doctrines to describe how people can evaluate their spontaneous, unexamined preferences critically. These theories differ in important respects, yet they share the belief that people can scrutinize, refine, or transcend their original preferences through dialogue with people who possess different preferences, even if the latter are unexamined as well.

The theorists advocating a more deliberative political life are the least precise when discussing the criteria for examining, evaluating, and revising people's unexamined preferences. Contemporary republican-oriented legal theorists addressing these concerns tend to appeal to some combination of history and experience, especially the shared experiences of the community, as recognized by its current members. ${ }^{99}$ Virtually all question the significance of absolute or transcendent standards for distinguishing correct from incorrect moral and political judgnients. ${ }^{100}$ The thrust of these theories is that exposure to other people's opinions and preferences provides distance,

Constitutional Theory, supra note 97, at 24 (noting the inconsistency between Ackerman's emphasis on the quality of political life during constitutional moments and other claims he anakes for the dialogic community). As Paul Kahn has observed, the "focus on the particular history of this community replicates much of the function of will in classical theories of consent." Id. at 4.

99. The views of contemporary republican-oriented theorists range from complete rejection of transcendent standards to making political agreenent a condition of the legitimacy of sucli standards for political life. See, e.g., Michelman, Law's Republic, supra note 15, at 1524-29 (asserting that the normative standards are created, not just discovered, by the community); Michelman, Traces of SelfGovernment, supra note 14, at 29, 31-33 (noting that applying normative standards is an "empathic" thought, which "implicitly test[s] itself against the views of others"); Sherry, Civic Virtue, supra note 15, at 548 (adopting a classical (non-Aristotelian) paradigm in which a community selects its values and goals based upon "rational thought, intuition, and tradition," thereby creating an immanent shared telos "defined in the contcxt of the historically bound community that aspires to it"); West, Liberalism Rediscovered, supra note 15, at 674-75, 680-82 (arguing that we can learn about the good life by reviewing history and the empirical data of experience with practical reasoning and a critical stance); see also Kahn, Community in Contemporary Constitutional Theory, supra note 97, at 3-4 (contemporary constitutional theory emphasizes communities of discourse through which common values are discovered and elaborated); see also supra notes 97, 98 .

Several theorists have linked this approach to the discovery of political and moral truths to the philosophy of pragmatism or to feminist theory as well as to the theory of practical reasoning contained in Aristotle's writings. See Hirshman, The Book of "A," supra note 18, at 972-85; West, Liberalism Rediscovered, supra note 15, at 680-82. See generally Margaret J. Radm, The Pragmatist and the Feminist, 63 S. CAL. L. Rev. 1699 (1990).

100. 1 Ackerman, We the People, supra note 15, at 12-14 (rejecting foundationalism); PerRy, MORALITY, PoLmics, AND LAW, supra note 34, at 31 ("There is no evaluative perspective outside self or tradition."); id. at 40 ("[t]here is no privileged standpoint from which to adjudicate among different webs of beliefs"); Michelman, Law's Republic, supra note 15, at 1510-11 (arguing that no purely transcendental argument, one that is theoretically or lypothetically based, can impart to laws the authority of self-government); Michelman, Traces of Self-Government, supra note 14, at 23 (arguing that to satisfy "modern individualistic concerns," practical reason "must be a process of normative justification without ultimate objectivist foundations"); Sunstein, Beyond the Republican Revival, supra note 14, at 1554 (rejecting the need for "ultimate foundations"); West, Liberalism Rediscovered, supra note 15, at 674 (arguing that liberalism views the good life as an evolving concept); see Kahn, Community in Contemporary Constitutional Theory, supra note 97, at 4 (contemporary theory las substituted "discursive particularity" or "historicized reason" for the objective, universal precepts of earlier reason-based constitutional theories). But see Derek L. Phillips, Authenticity or Morality?, in The Virtues: Contemporary Essays on Moral Character 23, 31 (Robert B. Kruscliwitz \& Robert 
hence perspective, for judging our own opinions and preferences, assuming that we histen to others with an open mind.

In discussnig the dynamics of examining and revising opinions through what he calls jurisgenerative politics, Frank Michelnıan poses several hard questions critical to the enterprise's success. He asks first how we can be certain that new opinions have been adopted out of an honest conviction about their correctness rather than from "giving in" to others out of a desire to avoid or overcome an impasse. ${ }^{101}$ Michelman's concern is that unless "deliberation [is] a magic guaranteed to create an authentic consensus," any outcomes agreed upon could be coerced rather than voluntary, strategic rather than felt. ${ }^{102}$ For Michelman, genuine persuasion presupposes live ${ }^{103}$ encounters with people possessing different perspectives. ${ }^{104}$ The result of this interaction may be that some or all of the participants exchange their views or that new views emerge from the discussion. Alternatively, the interaction accomplishes its purpose if the participants

C. Roberts eds., 1987) (advocating that conduct be guided by morality rather than authenticity and arguing that questions of right and wrong can be as objective as empirical questions).

101. Michelman, Traces of Self-Government, supra note 14, at 21. Michelman appears skeptical that genuine consensus can be reached even when all the participants act in a "civically virtuous" manner. Id.

102. Id. See Michelinan, Law's Republic, supra note 15, at 1526-28 (describing the conditions of a noncoercive transformative political process). Relying on the thought of Jürgen Habermas, Michelman defines the "ideal speech situation" as "a setting m which everyone, free of domination and false consciousness, speaks out, listens, gives and is given reasons to and by everyone else." Id. at 1526 n.135. Michelman appears to doubt that genuine agreement concerning a decision is always possible. See id. at 1526-27. His writings do not adopt this view explicitly, and he raises the possibility that deep agreement is not always a precondition of noncoereive consensus. Id. at 1527 . However, if genuine differences of opiuion can survive the ideal speech situation, it is difficult to see why there won't be soine who "give im" to others' views to avoid an impasse. See, e.g., Kroninan, Living in the Law, supra note 76, at 860-61 (arguing that enduring differences of opinion exist, and that in such cases, statesmanship should promote "fraternity" among those who disagree rather than tolerance or false unanimity).

103. Michelman gives the impression that the encounters must be live (face-to-face) to be effective. See Michelman, Law's Republic, supra note 15, at 1531 (arguing that dialogic engagement "must occur in various arenas of what we know as public life in the ... interactions and debates that arise in and around town mcetings and local government agencies; civic and voluntary organizations; social and recreational clubs; schools public and private; managements, directorates and leadership groups of ... all kinds"); Michelinan, Traces of Self-Government, supra note 14, at 27 (arguing that normative reason cannot be solitary; it presupposes "encounter with different outlooks in public argument"). However, Michelman sceins to have had just such an encounter with the writings of James Harrington, as 1 have had with the writings of Michelman.

104. See Michelman, Law's Republic, supra note 15, at 1528-31. He does not seem to require that the other people's perspectives be examined or well thought-out, only that they provide a contrast. Michelman's approacl recalls Aristotle's method of sifting through opinions to discover what is true: he uses a dialectical method that begins from the beliefs held by "all people, most people, or the wiseall of the wise, most of the wise, or the most distinguished." ARISTOTLE, Topics 1.1 100b21-23. In other words, unreflective opinions (such as the opinions of "most people") may play a useful role in the discovery of truth for Aristotle as well. On the importance of including diverse points of view for ensuring the rational character of dialogue, sce Solum, Virtues and Voices, supra note 14, at 122-27, 131-32, 136-37. 
"hold the same commitments [but] in a new way," 105 presumably with a greater understanding of the premises presupposed or the consequences entailed.

Michelman also emphasizes the importance of people whose viewpoints are outside the mainstreain. Such people are especially useful in the confrontation and discovery process because their outsider status has forced them to appreciate more than one perspective: the mainstream perspective and their personal perspective. ${ }^{106}$ "Margmal" perspectives are thus important for the dynamic of self-criticism both because they inject fresh points of view into the reasoning process and because they tend to be more comprehensive than mainstream perspectives. As a result, the marginal character of outsiders' opinions may make such people more insightful about relationships and conflicts among various opinions than are their mainstream counterparts. That is to say, "outsiders" may be more insightful about the nature and limits of unexamined opinion.

Michelman presents this account of the dialogic process to answer a second difficult question: how can one expect new ideas or perspectives to "penetrate the dominant consciousness?"107 This question is broader than the first because it addresses more than the difficulties people experience in coming to appreciate other people's opinions. It also asks how, when people's unexamined opinions mirror the conventional wisdom, they can overcome complacency or unwarranted confidence about the naturalness or correctuess of the opinions they share with the dominant culture. Michelman's answer focuses on hive exchanges with "outsiders" because such people have the greatest incentive to mount a forceful challenge to people's culturally reinforced, unreflective assumptions, thereby prodding people to question, if not doubt, the legitimacy of these assumptions.

Michael Perry similarly explores the cognitive dynamic at work when people refine or change their pre-existing opinions. For Perry, a basic unit of human cognition is a "web" of behefs; that is, a group of beliefs that are reasonably, if not perfectly, linked and consistent. ${ }^{108}$ Perry believes people typically have multiple webs of beliefs: the web of beliefs associated with their religious convictions, the web of beliefs associated with their political convictions, and so on. Each web characterizes a community, for example, the community of liberal Catholics, of American liberal democrats, or of

105. Michelman, Law's Republic, supra note 15 , at 1527 (quoting HanNa F. PITKIN, Fortune Is A Woman: Gender and Polmits in the Thought of Niccoló Machiavel.li 279 (1984)).

106. Id. at $1529 \&$ n.148 ("[P]ursuit of political freedom through law depends on 'our' constant reach for imclusion of the other, of the hitherto excluded."); see id. at 1530 (describing how the aspirations and activities of Black Americans helped transform the "dominant consciousness" of White Americans).

107. Id. at 1530.

108. See PerRy, MoraltTy, Polmitcs, AND LAw, supra note 34, at 27-30 (positing that a web of behefs is a system of beliefs that an imdividual or community usually perceives as certain). 
radical feminists. ${ }^{109}$ Thus, from a cognitive viewpoint, most people are members of multiple communities. According to Perry, this is possible because "for a large range of propositions nearly all frameworks coincide."110 He sees the self as constituted, at least in part, by a person's moral convictions and commitments. ${ }^{111}$ Thus, for Perry we are at once part of multiple communities external to us and custodians of those communities within us.

Perry calls the deliberative decisionmaking process "deliberative, transformative politics," which he contrasts with political activity that is selfish or manipulative and in the service of unexamined preferences. ${ }^{112}$ Like Michelman, ${ }^{113}$ Perry stipulates that meaningful discussion and revision of beliefs must be communal. ${ }^{114}$ Both authors emphasize that meaningful discussion presupposes a considerable number of beliefs that the participants have in common. ${ }^{115}$ These shared beliefs constitute the "points of departure" of productive moral discourse. ${ }^{116}$ In other words, a commumity's shared beliefs constitute a "grid" of fixed points that enable its members to communicate intelligibly with each other about points of contention.

Perry thinks the dynamic of discussion and revision of beliefs exists whether an individual is self-critical about her own beliefs or the whole community is self-critical about its normative franıework and traditions. ${ }^{117}$

109. See id. at 29. Perry argues that a community exists when the extent of agreement about moral questions exceeds the extent of disagreement. Id. (quoting Stanley Hauerwas and discussing the relationship between moral beliefs and one or more communities).

110. Id. at 51 (quoting Philip E. Devine, Relativism, 67 Monist 405, 412 (1984)). Although Perry uses the quotation to explain how members of a pluralistic society are able to converse with one another, the same observation appears relevant to the diversity of communities, or webs of beliefs, within ourselves.

111. Id. at $60,62,72$.

112. Id. at $4,151-52$.

113. See supra notes 103-04 and accompanying text.

114. Perry calls this "productive moral discourse." Perry, MoraltTy, Politics, and Law, supra note 34, at 3-4. He stresses that basic beliefs about the good life are "less the property of individuals than of communities." Id. at 29; see id. at 32 (arguing that this situation exists because moral belicfs are beliefs of human beings qua members of communities and not qua humans simply). It seems that Michelman would accept the intersubjective nature of cognition, but not the intersubjective view of human nature (given his rejection of a single or fixed human telos, not to mention a shared or common telos). See Michelman, Law's Republic, supra note 15, at 1528-29 (stating that if political life is conceived as necessarily pluralistic, it will also be characterized by legal indeterminacy, and its normative content must be created by those who participate in political discourse); Michelman, Traces of Self-Government, supra note 14, at 22-23 (rejecting classical republicanism's normative teleology); see also Sherry, Civic Virtue, supra note 15, at 547 (discussing the classical paradigm and agreeing that "self-knowledge is a communal project"). Although Perry typically talks about "moral" discourse, he says that his remarks concerming "belief revision extend beyond moral beliefs to beliefs generally, including scientific beliefs." Perry, MORaltTy, Politics, and LAw, supra note 34, at 29.

115. Perry, MORality, Polmics, AND Law, supra note 34, at 50-51; Michelnan, Law's Republic, supra note 15, at 1513; see Michelman, Traces of Self-Government, supra note 14, at 13 (describing Robert Cover's concept of a "paideic" community, i.e., a comnunity formed by strong interpersonal bonding through a shared commitment to a speeific moral tradition and its contemporary elucidation).

116. Perry, Morality, Polmits, and Law, supra note 34, at 52.

117. Id. at 30 ("The revision of self and the revision of tradition are analogous."). 
In either case, the presence of an unchanging core of existing beliefs makes scrutiny and revision of noncore existing beliefs possible. Revision, whatever its form, can only take place by reference to unquestioned beliefs. ${ }^{118}$ As a consequence, although Perry thinks that all beliefs are in principle subject to revision, not all can be questioned or revised simultaneously or in the space of a short period of time. ${ }^{119}$

Because deliberative democracy presupposes the willingness and ability of the participants to be self-critical and to be open to differing viewpoints, both Perry and Michelman praise these attributes in individuals and the counterpart virtue of tolerance im political communities. ${ }^{120}$ According to Perry, not only do many communities admit the provisional character of their beliefs, they may "even encourage . . . the exercise of self-critical rationality." 21 In his view, "at their most vital, traditions are self-transcendent." 122 Similarly, Michelman exalts "law's self-revisionary aspect, echoing the self-critical dimension of moral and political freedom."123 The fund of normatively effective material constituting a political community is always "contestable."124 Consequently, citizenship properly understood should be equated with "foundership," which Michelman defines as "the constant redetermination by the people for themselves of the terms on which they live together." 125

\section{B. The Willingness to Talk, Listen, and Abide}

As the preceding makes clear, legal theorists who advocate a more deliberative public decisionmaking process have explored in some detail the cognitive dynamic whereby people's unexamined preferences can be scrutinized and, as a result, revised, abandoned, or retained with a deeper meaning than existed initially. Although essential and insightful, these theorists' descriptions of the dialogic process are ultimately less persuasive than they might be because they lack a credible account of motivation. Motivation is critical for the success of the deliberative enterprise at three stages. To

118. Id. at 28, 30-31. Perry also envisions the possibility that core beliefs may at some point be altered or even abandoned as a result of the integration of new beliefs. Id. at 30 .

119. Id. at 28.

120. Id. at 102-03 (rejecting neutrality and applauding tolerance); Michelman, Traces of SelfGovernment, supra note 14, at 31-33 (summarizing the modern project of reconciliation through public dialogue).

121. Perry, Moraltry, Polmits, and Law, supra note 34, at 30.

122. Id. at 31. For Michelman's account of Justice Brennan's constitutional jurisprudence as exalting people's "self-critical, self-transformative capacities," see Frank I. Michelman, The 1990 McCorckle Lecture: Super Liberal: Romance, Community, and Tradition in William J. Brennan, Jr.'s Constitutional Thought, 77 VA. L. REv. 1261, 1264-83 (1991) [hereinafter Michelman, Super Liberal].

123. Michelman, Law's Republic, supra note 15, at 1514. Michelman underscores Dworkin's account of law "as integrity" as "bottomlessly interpretive" and observes that Dworkin's theory is "all but indistinguishable" in this respect froin Michelman's portrait of republican inspired politics. Id.

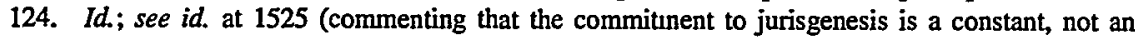
episodic, activity).

125. Id. at 1518 . 
begin with, deliberative deinocracy can never be a reality unless people are willing to enter into the public dialogue in the first place. Secondly, it presupposes that people will histen fairly, participate honestly, and be open to persuasion (where appropriate) by the power of opposing arguinents. Finally, there must be soine form of motivation to abide by results adverse to pre-existing preferences that people still want to satisfy.

A person's willingness to enter into the public dialogue is problematic because a critical premise of the deliberative process is the possible illegitimacy of one's own unexamined preferences or opinions. To most people this possibility is not obvious, and, indeed, is counterintuitive. Yet the willingness to question one's unexamined preferences is a necessary condition for entering the dialogne voluntarily and being capable of learning and growing from it.

How do the contenporary legal theorists with republican concerns address this threshold issue of motivation? In one sense, Michael Perry avoids this dilemma by explicitly assuming a commitment to flourishing. In the first chapter of Morality, Politics, and Law, Perry maintains that it is impossible to justify a commitment to the value of flourishing without being circular. ${ }^{126}$ Even if he is correct, his observation is irrelevant to the practical question of how people acquire such a commitment and what steps the government, educators, or the family should take to ensure that people will possess that commitment. The reason is that most people committed to flourishing have developed that commitment before ever encountering a theoretically rigorous justiflcation for doing so.

Thus, Perry's assertion that there is "perhaps nothing to say" to someone who is not committed to flourishing because "[in]oral discourse always presupposes the acceptance of humanity and the striving to be and to becoine ever more fully human," 127 is not sufficient. First, even if true, the question to be addressed is not inerely under what conditions productive moral discourse is possible (answer: when people are committed to flourishing), but rather what, if anything, can we do to ensure that people grow up committed to flourishing so that productive inoral discourse will be possible. Second, even in a group where all members are committed to flourishing, there may be disagreement over the deflnition of flourishing or what constitutes "striving to be ever more fully huinan." If, for example, some people envision flourishing as maximizing their unexamined preferences, their commitment is unlikely to lead to productive moral discourse. Since Perry concedes this diversity of views, ${ }^{128}$ it is not enough to posit simply that people cannot prove the importance and nature of flourishing to others lacking a commitınent to it and productive moral discourse.

126. Perry, Morality, Polmics, and Law, supra note 34, at 15-16.

127. Id. at 17 (quoting Roberto M. UNGer, KNOWLEDGe AND PoLmTICs 196 (1975)).

128. Id. at 15,23 . 
Perry says he considers the threshold motivational question to be less interesting than the mechanics of productive moral discourse once it is already set in motion. ${ }^{129}$ Yet this motivational question turns out to be one of the leitunotifs of his book, addressed explicitly by him on two occasions and raised sub rosa in several other places. In the former category, Perry once asks how it happens that a person revises or at least questions her beliefs. He answers that she may at some point become aware that her beliefs are inconsistent, or she may at some point become unwilling to accept the inconsistency, or some newly acquired belief may suddenly create an inconsistency or otherwise unsettle her existing web of beliefs, or someone may challenge some of her behefs in a way "she cannot ignore." 130 The trigger for her questioning, in other words, is itself cognitive. A logical inconsistency or incoherence sets her in motion.

The sanie understanding underlies Perry's second explicit treatunent of the motivation behind examination and revision. In describing the likelihood that a community will promote tolerance for a diversity of opinions, Perry says that people sharing his hope that such communities will prevail "can do more than hope: [they] can talk."131 By this, Perry appears to mean that those sharing his hope can attempt to persuade people as to the general desirability of this goal. Common to these two passages is Perry's faith that the willingness to enter into a deliberative process can be triggered by an appeal to the potential participant's reason, through the power of argunient, and the desire to have logically consistent beliefs.

Elsewhere in his book, Perry reveals a different understanding of the notivation for engaging $\mathrm{m}$ public deliberation rather than succumbing to one's unexamined preferences. On several occasions, he conditions the success of productive moral discourse on such things as "good faith," "a gentle, ecumenical openness to the beliefs, experience, and person" of those who disagree, and love of one's neighbor. ${ }^{132}$ In addition, his claim about the pervasiveness of communities encouraging self-critical rationality among their members ${ }^{133}$ itself reveals his understanding that the inclination to be self-critical can be inculcated culturally. However questionable the premise, ${ }^{134}$ his praise of good faith, neighborly love, and gentle, ecumenical openness amounts to a tacit admission that in niany instances the possibility

129. Id. at 27 .

130. Id.

131. Id. at 103.

132. Id. at $51-52$.

133. See supra text accompanying note 121 .

134. See Michael W. McConnell, The Role of Democratic Politics in Transforming Moral Convictions into Law, 98 YALE LJ. 1501, 1506-09 (1989) (book review) (challenging Perry's claim that religious and other communities encourage self-critical rationality as factually inaccurate and arguing that a tradition that considered all its teachings as provisional would contain the seeds of its own destruction); Michael Zuckert, Book Review, 6 CONST. COMMENTARY 446, 449 (1989) (writing of Perry that it is "deeply problematic to use some parts of the conventional morality against other parts, for as convention all parts are of equal authority"). 
of the deliberative cognitive virtues presupposes the existence of certain moral virtues or attributes of character.

Suzanna Sherry also recognizes the importance of character for the deliberative project but does not directly address the practical issue of fostering the moral character traits that would facilitate the deliberative process. In Civic Virtue and the Feminine Voice in Constitutional Adjudication, she develops the thesis that the feminine perspective closely resembles the republican political paradign, whereas the masculine perspective has a parallel kinship with the liberal political paradigm. ${ }^{135}$ The republican paradign emphasizes the moral attributes associated with civic virtue, while the feminine perspective correspondingly emphasizes such qualities as responsibility, concern for the needs of others, commitment to the good of the group, compassion, and related character traits. ${ }^{136}$ Sherry argues that women and the femmine perspective have been underrepresented in American politics and law. As a result, our Constitution and our legal and political systems are dominated by the liberal values of self-interest, autonomy, lack of group feeling or connection, and abstractness. ${ }^{137}$ She concludes by suggesting that the affirmative effort to inject the feminine perspective into law and politics would result in a more public-spirited and deliberative commumity. ${ }^{138}$

In describing the classical republican paradigm, Sherry mentions some of the things that the adherents of this paradigm believed would encourage or inhibit the development of civic virtue. For example, they viewed a certain level of private property as necessary for civic virtue, but excessive

135. Sherry, Civic Virtue, supra note 15, at 543-44; id. at 582 (stating that the feminine perspective and the classical [republican] paradigm are not completely congruent, but "the similarities are too strong to ignore"); see id. at $\mathbf{5 7 9}$ (arguing that some men have the feminine perspective and some women, the masculine perspective, but women as a group exhibit the feminine perspective to a far greater degree than do men).

For a similar characterization of the difference between masculine and feminine perspectives and the identification of the masculine perspective with the liberal legal paradigm, see Robin West, Jurisprudence and Gender, 55 U. CrI. L. REv. 1, 2-7 (1988). In contrast to Sherry, however, West concludes that critical legal thought (which she appears to associate, at Icast in part, with commumitarianism) presupposes the fundamental material separateness of human beings as much as liberal legal thought; the two traditions differ in that critical legal theorists see this separateness as an imperfection that human beings long to overcome. Id. at 9-11. Thus, for West, both of the two main opposing legal theory traditions are deeply rooted in masculine assumptions about human nature. Id. at 2. As a consequenee, sle argues that there is only a superficial similarity between cultural feminism (with which Sherry is associated) and critical legal theory. Id. at 38-42 (for the cultural feminist, women value things like love and intimacy because they express their deepest nature; whereas for the critical legal theorists, men long for similar bonds to overcome part of their nature).

136. Sherry, Civic Virtue, supra note 15, at 580 (describing the feminine and masculine perspectives as identified by feminist scholars in philosophy, history, sociology, art, and anthropology); see id. at 582 (describing masculime rule-based and feminine "contextual" perspectives on the law); id. at 584-91 (discussing the different perspectives as manifested in literary criticism, psychology, and philosophy).

137. Id. at 581-84, 613-16.

138. See id. at 544, 581, 613-16. 
wealth as its enemy. ${ }^{139}$ They believed that participation in the deliberative process could itself be a source of civic virtue. ${ }^{140}$ Finally, they thought classical republican citizens would rarely act voluntarily in accordance with virtue unless the demands of virtue were internalized. Hence, an education einphasizing virtue was a basic ingredient of the republican paradigm. ${ }^{141}$

Sherry fails to draw out these observations in her vision of a contemporary return to republican values. She observes that woinen owe their distinct perspective to their upbringing, socialization, and characteristically feminine experiences. ${ }^{142}$ Yet surprisingly, she does not discuss what those sharing her interest in creating a more republican political community should do. For example, how does one ensure that male children and young adults will have the republican life experiences naturally afforded females so that they may also acquire the feminine perspective? This omission is especially curious in light of Sherry's observation that "[t]eaching is not always a matter of either arguing or providing evidence. ... It is sometimes rather a matter of miparting a way of looking at things."143

There are several possible explanations for Sherry's omission. First, she finds "the inost persuasive" explanation for the difference in feminine and masculine perspectives to be the theories of Nancy Chodorow and Carol Gilligan. According to these authors, the masculine perspective can be traced, in part, to the desire of inales to separate froin, and hence repudiate the perspective of, their (usually) female primary caretakers. Fennales, on the other hand, reaffirm feminine values because they identify with their (usually) feinale primary caretakers. ${ }^{144}$ If this claim is true, it will be difficult for males to be "feminized" to have republican virtues except in those instances, for example, where the primary caretaker both was inale and affirmed the cluster of values associated with the feminine perspective. Alternatively, Sherry may believe that the inost effective way to universalize republican values is through a feminine jurisprudence perneating constitutional adjudication. The latter interpretation is suggested by the focus in one of Sherry's articles on Justice O'Connor's feminine jurisprudence

139. Id. at 556; see Sunstein, Administrative Substance, supra note 15, at 612 n.20 (explaining why private property was important to traditional republicans).

140. Sherry, Civic Virtue, supra note 15, at 555-56. For a contemporary discussion of this possibility, see Richard Briffault, Our Localism: Part II-Localism and Legal Theory, 90 CoLum. L. REv. 346, 396 (1990).

141. Sherry, Civic Virtue, supra note 15 , at 556-57.

142. Id. at $580-81,586-88$. Sherry thus seems to attribute the femimine perspective primarily to developmental, not biological, aspects of women's hives. On this distinction, see West, Jurisprudence and Gender, supra note 135, at 20-27.

143. Sherry, Civic Virtue, supra note 15, at 615-16 (quoting Richard Eldridge, On Knowing How to Live: Coleridge's "Frost At Midnight," 7 PHI. \& Literature 213, 227 (1983)) (alteration in original).

144. Id. at 580 n.168. 
and the jurisprudence of those male justices who also exemplify republican values. ${ }^{145}$

In an analysis of hate speech regulations written several years after Civic Virtue and the Feminine Voice, Sherry states that virtue presupposes an internal state of mind or set of beliefs adopted by choice. ${ }^{146}$ Consequently, it cannot be "coerced," but must be selected or adopted voluntarily. ${ }^{147}$ Coercion can at most compel a certain type of conforming behavior, whereas virtue is the coincidence of praiseworthy behavior and a matching deeply held belief. According to this view, belief systems can be influenced by critical thinking but not by coercive measures such as censorship. ${ }^{148}$ It is unclear how Sherry reconciles her views on virtue as a product of uncoerced belief systems with her earlier acceptance of theories attributing the feminine perspective to early childhood experiences. ${ }^{149}$ Nevertheless, the overall thrust of her writing suggests that Sherry, like Perry, emphasizes the cognitive origins of the deliberative virtues at the expense of their inoral or character foundations. ${ }^{150}$

Frank Michelman explicitly rejects the civic virtue emphasis of Sunstein and other republicans on the ground that this aspect of republicanism is not appealing because it cannot give an account of why people would want to participate in a republican political community. ${ }^{151}$ In contrast, the appeal of the twin goals of the jurisgenerative political community that Michelman envisions-freedom and self-government-is "basic and unde-

145. Id. at 592-613. The omission may also derive not from theoretical considerations, but from an initial practical decision to limit this particular article to one aspect of the republican rcvival. Of course, such "practical" decisions may themselves reflect a hierarchy of priorities with theorctical significance.

146. Suzanna Sherry, Speaking of Virtue: A Republican Approach to University Regulation of Hate Speech, 75 MinN. L. REv. 933, 934-35, 944 (1991) (arguing that regulation of hate specch by universities is contrary to their mission and, in addition, will not achieve its purpose of making students virtuous).

147. Id. She contrasts manners with virtue: manners can be coerced and thus, for example, coercive government regulations can have a salutary effect on manners, but not on virtue. Id. at 935-36.

148. Id. at 944 . Sherry mentions that imparting belief systems or moral values to children is "arguably" an appropriate function for primary and secondary schools. Id. at 942-43. Univcrsities, however, should not attempt to perform this function because their mission is imparting knowledge, and they are unlikely to be successful in any event because young adults "have already acquired a nearly unalterable belief system." Id. at 944 . One further implication of her description of virtue as the coincidence of an internal state of mind and matching behavior is that primary and secondary schools can successfully teacl virtue. However, Sherry appears to be uneasy with this conclusion, presumably because the mitial (ehildhood) internalization of values was not chosen or "voluntary." See id. at $942-$ 43; see also infra Part V.A for a partial reply based upon Aristotelian texts.

149. See supra notes 144,148 and accompanying text.

150. In contrast to her tendency in the two articles just discussed, in a review of Amy Gutmann's book Democratic Education, Slierry discusses the inportance of moral conditions for the willingness to engage in the deliberative enterprise. Suzanna Sherry, Republican Citizenship in a Democratic Society, 66 TEx. L. REv. 1229, 1232-33, 1235 (1988). For a discussion of Gutmann's political theory, sce infra text accompanying notes 222-28.

151. Michelman, Traces of Self-Government, supra note 14 , at 19-20. 
niable."152 At the same time, he defines self-government in a way requiring individuals seeking their own freedom and self-government to realize the counterpart aspirations of others. ${ }^{153}$ According to Michelman, therefore, the character traits that are necessary for jurisgenerative politics are (in addition to the specific normative content of a particular community) universally praiseworthy habits of character sucl as fellowship and respect for others"154 and a commitment to a "good faith pursuit of the common good."155 However, Michelman views these inoral virtues as ultiniately instruniental to his more individualist concept of persons as selfgoverning. ${ }^{156}$

Like Perry and Sherry, Michelman focuses on the power of ideas to create or sustain a commitment to social plurality and never asks which character traits are necessary to encourage people to seek out or be receptive to argunient in the first place. In one passage addressing the threshold question of notivation, Michelman asserts that through judicial review the Court can challenge " 'the people's' self-enclosing tendency to assume their own inoral conipletion as they now are and thus to deny to theniselves the plurality on which their capacity for transformative self-renewal depends." 157 He has in mind interventions by the Court to invalidate legislation that violates the norm of social plurality. For example, the Court should have struck down the Georgia statute under challenge in Bowers $v$. Hardwick, ${ }^{158}$ but it should not have justified its decision on the basis of the traditional doctrine of privacy. Doing so simply would "reinforce the idea 'that homosexuality is merely a form of [bedrooin] conduct . . . rather than

152. Id. at 24; see id. at 19 (the republican conception of civic virtue is not "persuasive to modern liberal sensibility"); id. at 22 (the unitary republican understanding of the human end "runs against the modem liberal temper"). By the modem hberal temper Michelman means primarily the deliverance of "individual subjectivity from social conformist oppression," rather than "possessive individualism." Id. at 19 n.87.

153. Id. at 75 .

154. Id. at 40,75 .

155. Id. at 40. As a result of this strand of Michelman's writings, Steven Gey sees little difference in the coercive aspects of Michelman's and Sunstein's theories. Gey, The Unfortunate Revival, supra note 16, at 862-64, 872-73. In fact, Michelman appears to be a much less whole-hearted civic republican than Sunstein.

156. See Michelman, Traces of Self-Government, supra note 14, at 47 (approving of that aspect of the works of Harrington that presents objective notions of the common good and civic virtue as "essential" to the republican conception, but not "fundamental within it"); see also id. at 40 . The fact that political dialogue is uitimately imstrumental to human freedom (in that it is sought as a condition of freedom and not as a good in itself) does not make Michelman's republican orientation superficial. $C f$. Michelman, Super Liberal, supra note 122, at 1288 (asserting that the "collectivist" character of socialstructural projects to ensure "openness to public controversy" is only "skin deep" because it is in the service of liberal ideals such as autonomy and freedoin). In my view, the implication of Michelnan's conception of political dialogue goes deeper into our (his) understanding of hunan nature than he admits. If political dialogue, as Michelman understands it, is essential not inerely to keep the peace, but to open our eyes and minds to human truths, then political dialogue is constitutive of human freedom and, as a consequence, of human nature and happiness.

157. Michelman, Law's Republic, supra note 15 , at 1532.

158. 478 U.S. 186 (1986). 
a continuous aspect of identity' demanding public expression."159 Rather, the Court slould have used the occasion to broaden the foundation of the concept of privacy by emphasizing its relationship to citizenship. This approach was taken by Justice Blackmun in his dissent, where he called attention to the importance of intimate associations for the development of personal identity. ${ }^{160}$

No doubt the courts, especially the Supreme Court, can be a source of moral education, a force for questioning and revising beliefs, and an instigator of public dialogue with deep, pervasive, and permanent effects on both the opimions and characters of the citizens at large. ${ }^{161}$ At the same time, the disproportionate attention paid to the Court's role by contemporary republican legal theorists, as contrasted with the limited attention paid to the importance of citizens in general, ${ }^{162}$ goes hand in hand with these theorists' tendency to ignore the moral foundations of deliberative dialogue. In a sense, therefore, Perry, Sherry, Sunstein, and Michelman are preaching to the converted: to people, such as judges and acadeimics, who have already demonstrated a moral and cognitive disposition to live an examined life. This group, by self-selection, tends to value reflection and to have the corresponding character traits by the time they begin reading these theorists' works. To be successful, however, their theories must somehow account for people other than those who read their books and articles. At the very least, these theorists should address the people who still equate preferences

159. Michelman, Law's Republic, supra note 15, at 1534 (quoting LAURENCE H. TRIBE, AMERICAN ConstrTutional LAW § 15-1, at 888 (1st ed. 1978)) (alteration in original).

160. Id. at 1535-36. Elsewhere Michelman emphasizes the role of the courts, especially the Supreme Court, in galvanizing the republican virtues in citizens by itself exhibiting those virtues in its decisions. Michelman, Traces of Self-Government, supra note 14, at 74-77. On this aspeet of Michelman's work, see Kahn, Community in Contemporary Constitutional Theory, supra note 97, at 2837. Kahn criticizes Michelman's thesis that the Court can be the locus of republican self-government in the United States on the grounds that Michelman's larger theory offers no justification for the Court's actions being authoritative. Id. at 35-37.

161. The classic example is the Court's role in accelerating the nation's understanding of the reprehensible nature of segregation through its decision in Brown v. Board of Education, 347 U.S. 483 (1954). Of course, much of the lesson could have been lost had President Eisenhower not showed his willingness to use the coercive power of the state to reinforce it. Some commentators rejeet the preceding interprctation of the Brown decision. See 1 Ackerman, We the People, supra note 15, at 131-62 (stating that by rejecting the separate but equal doctrine as applied to education, the Court in Brown was clarifying and preserving the Fourteenth Amendment as enacted, not prophesying or engineering a new political consensus); Louis M. Seidman, Brown and Miranda, 80 CALIF. L. Rgv. 673, 673, 750-53 (1992) (arguing that, although the Brown decision was legislative, its effect was a retreat from a more radical constitutional politics because it created a false sense of "closure and resolution").

162. This tendency has been criticized by others. See Kathryn Abrams, Law's Republicanism, 97 Yale L.J. 1591, 1592, 1594-98 (1988) (referring to Michelman); cf. 1 ACKerman, WE the PeOple, supra note 15, at 295-322 (endorsing a dualist theory of U.S. constitutional law in which informed, public-spirited, and mobilized citizens develop and articulate constitutional prineiples, and the Court is limited to protecting past popular constitutional utterances or, in the case of "structural amendments," codifying informal popular constitutional utterances); $i d$. at 139 ("It is not the special province of the judges to lead the People onward and upward to new and higher values. This is the task of citizens who may, after the investment of great energy, succeed (or fail) in gaining the considered assent of a majority of their fellows."). 
with interests and for whom the pursuit of happiness entails satisfying those preferences to the utmost.

After people have come together to engage in a deliberative dialogue, some of the motivational issues just discussed remain; however, the manner m which the deliberative process is organized may influence the second stage motivational issues. Assuming voluntary initial involvement in a political debate, three basic scenarios can be envisioned. ${ }^{163}$ First, a person may engage in public dialogue with the sole objective of "winning" by overpowering those who espouse different points of view. In that instance, the person "listens" only to discover the weaknesses in the other participant's arguments or in their argumentative abilities. The person recognizes the importance of listening to others carefully, but the carefulness is im the service of victory, not understanding. Second, a person may histen to others out of a respect for their right to voice their opimions, but without intending to take their views seriously. As contrasted with the combative first type, this person is more likely to be influenced ${ }^{164}$ by what he hears. Although not disposed to learn from others, this person is not resistant either. Thus, the degree and kind of influence the other participants have will be a function primarily of their talent for debate and reasoning. Third, a person may listen "empathetically,"165 making an effort to find the common ground uniting the participants and hoping to reach mutual and felt agreement on the issues under consideration. 166

163. The three scenarios presented here are based upon Barber, Strong Democracy, supra note 35, at 175; see also Gey, The Unfortunate Revival, supra note 16, at 834-35, 840 (arguing that republican legal theorists never explain how dialogues will lead to consensus or how a community's decisions can be enforced); cf. Charles Larmore, Political Liberalism, 18 POL. THEORY 339, 348-49 (1990) (asserting that "equal respect" for other persons will be sufficient to motivate people to engage in rational dialogue, both in the sense of willingness to talk and openness to persuasion).

164. I say "influenced" rather than "persuaded" because not every encounter will result in persuasion even if the participants listen carefully and sympathetically to one another.

165. Barber, Strong Democracy, supra note 35, at 175.

166. Benjamin Barber addresses the interaction between dialogue and motivation. At the outset he distinguishes between "talk" and "strong democratic talk." In the former, advocates present their views as part of a bargaining or bartering process. As a result, each advocate listens to the others only to the degree necessary to strike a bargain in which the parties all see themselves as benefiting. In strong democratic talk, in contrast, the participants have a conversation to discover common bonds as well as to explore issues, with the expectation that there will be no precise right or wrong solution. In strong democratic talk, in other words, the emphasis is on the shared "conversational journey" more than the exactness of the substantive outcoine. See id. at 182-86. Barber argues that, as a conceptual inatter, the impact of strong democratic conversation on the discovery or creation of common bonds among the participants is distinct from its impact on the discovery or creation of shared understandings. Id. at 185-86 ("[K]nowing others and caring for them are not psychologically or sociologically synonymous."). But he also observes that in some situations the cognitive function of conversation will itself help "to build friendship and nourish affection." Id. at 185. Further, even when the substantive explorations of a conversation do not in and of thenselves create a feeling of fellowship among the participants, the expressive and affective aspects of speech may generate bonds among thein. Id. at 18689 (discussing how the tone, color, volume, and infleetion of voices may reassure, unsettle, comfort, intimidate, soothe, and otherwise influence the feelings of those who listen). 
Much of what has been said so far applies as well to the motivational issues that arise in the wake of deliberative dialogue. The need to combine cognitive receptivity with a willingness to suspend or restrain one's unexamined preferences and desires is obvious, especially in the post-deliberative period. First, it is possible that a person's pre-dialogue beliefs or preferences will not be altered by the deliberative inquiry. Second, even if they are altered, a person's pre-dialogue desires may not be eliminated by the deliberative inquiry. This would occur whenever the deliberative dialogue is sufficient to persuade a participant as to the correctness of particular goals without simultaneously being strong enough to transform the participant's imitial desires to conform to the new understanding. Finally, even if the participants refine both their initial beliefs and their underlying desires as a result of the dialogue, there may remain practical disagreenient over the best way to achieve an agreed outcome. In short, even if people's character traits are sufficient to make them willing to enter a deliberative enterprise voluntarily, it does not follow that those who have failed to internalize the results, remain unconvinced, or otherwise oppose the outcome will be sufficiently influenced by the process to abide by the results.

As the preceding has inade clear, few of the contemporary legal theorists under consideration here have shown sustained interest in developing these issues systematically. ${ }^{167}$ This lack of attention makes their writings more abstract and less useful than would be the case if such issues were addressed directly and thematically. Further, the feasibility of political solutions offered by these republican-oriented legal theorists would be enhanced if they took into account the treatment of the relationship between character and reasoning by other disciplines, such as moral philosophy, political science, sociology, and psychology.

The remainder of this Article takes a first step in this direction by examining the writings of Aristotle as they bear upon the motivational issues raised. ${ }^{168}$ In particular, Aristotle's account of how practical reason

167. Some authors, however, have expressed concern over deliberative dialogue's potential for coerciveness. See, e.g., Gey, The Unfortunate Revival, supra note 16, at 820 (observing that civic republicanism may lead to forced citizen participation in deliberations about matters of no interest to imdividual citizens and may then implement collective decisions through the use of force); Michelman, Law's Republic, supra note 15, at 1507 (observing that a political outcome can be experienced as coercive if agreement is strategic rather than felt); Michelman, Traces of Self-Government, supra note 14 , at 21 (expressing concern about some of the motives of participants for agreeing to a group outcome without being persuaded); id. at 23 (expressing concem that agreement will be "ominously totalist" to contemporary audiences if all participants simply fall into line behind a value that dialogue has revealed to be superior).

168. Those authors who argue that in the best case political communities should have profound and irreconcilable disagreements hecause diversity of opinion is an essential ingredient of the search for truth need to give even greater emphasis than other republican-oriented legal theorists to the motivational problem of obeying "adverse" outcomes, since such diversity can often breed hostility among individual members of the community. The need to reconcile permanent and systemic heterogeneity of opinion with the pre-conditions of political stability would thus be a subset of the motivational questions raised in this article. See Fitts, Look Before You Leap, supra note 90, at 1657 
operates clarifies why understanding by itself is unlikely to motivate a person sufficiently to determine conduct and why the ability to reason or be reasonable itself presupposes the existence of certain character traits.

\section{III \\ Realizing Our Political Nature: The Aristotelian APPROACH}

\section{A. The Domain of Practical Reason for Aristotle and Contemporary Legal Theorists}

Central to theories that aim at some form of deliberative democracy is the process of practical reasoning. As was noted above, ${ }^{169}$ many contemporary legal theorists with repubhican concerns have rejected the model of demonstrative or syllogistic reasoning based upon universal truths im favor of some form of contextual reasoming process. ${ }^{170}$ The catalyst for this development is a growing appreciation of the importance of the particular for political discourse. This development seems to derive from two basic insights. First, because of their general nature, rules cannot capture the detail, concreteness, and complexity of political life. Political and moral rules, even if in some sense "true," are too abstract to furnish meaningful guidelines for the types of particular decisions that make up everyday life. A wealth of considerations would have to be added to any rule before it could be transformed into a prescription for action. Second, since human nature and circumstances are themselves evolving, general rules describing human affairs must be similarly evolving. ${ }^{171}$ As a consequence, the premises of political and moral reasoning cannot be known deductively or theoretically, but must be acquired as part of the practical reasoning process.

Aristotle develops his theory of practical reason primarily im the Nicomachean Ethics. ${ }^{172} \mathrm{He}$ presents practical wisdom, or prudence (phronësis), as the practical rational faculty that enables its possessor to

("Much of the political science literature suggests .... that ideological debate-discussing public problems in terms of fundamental questions and beliefs-can sometimes create and exacerbate divisions and disputes in a public political context.").

169. See supra Part II.A.

170. For political theorists with a similar approach, sce ANDERson, PRAGMATIC LIBERALISM, supra note 15 , at 156-58 (asserting that political principles are derived from debate and dialogue, not from syllogisms); id. at 161-65 (asserting that political reasoning depends on the force of arguments, not the application of rules); id. at 167-68 (asserting that political deliberation is more than a conversation since eacli person's input must be evaluated in light of standards derived from the situation); BARBER, STRONG DEMOCRACY, supra note 35, at xii ("Democratic politics is a form of human relations, and does not answer to the requirements of truth."); SPRAGENS, REASON AND DEMOCRACY, supra note 17, at 146-75 (developing a theory of liberal denocracy stressing collective prudence and rejecting the calculative ideal of deductive inference).

171. See supra notes $99-100$ and accompanying text.

172. Practical reason and the practical reasoning process are also discussed in De Anima 3.11 433a15ff. Excellent overviews of Aristotle's treatment of practical reason are provided by RoNaLD Beiner, Polmical Judgment 72-97 (1983) and Martha C. Nussbaum, Practical Syllogisms and Practical Science, in ARISTOTLE's DE MOTU ANIMALUUM 165, 165-220 (1978). 
deliberate well about what contributes to living well in a comprehensive, not a partial, sense. ${ }^{173}$ Practical wisdom is also presented as the excellence of the part of the soul that forms opinions. ${ }^{174}$ Practical wisdom differs from theoretical wisdom because it encompasses both universals and particulars, ${ }^{175}$ whereas theoretical wisdom deals with umiversals exclusively. ${ }^{176}$ Practical wisdom aims at knowledge of particulars, since its proper object is action, and actions are necessarily particulars. ${ }^{177}$ Because experience is important in understanding particulars, people with higher levels of experience but little scientific or universal knowledge may be better at practical reasoning than those who have such knowledge. ${ }^{178}$ Examples of the human activities that Aristotle presents as dependent upon practical wisdom are legislation, politics (in which he includes deliberative and judicial activities), and household management. ${ }^{179}$

\section{B. The Dependency of Practical Reason on Character}

According to Aristotle, practical wisdom cannot exist without good character im the form of moral excellence. ${ }^{180}$ Aristotle states that practical

173. ARIStOtLe, Nicomachean Ethics $6.51140 \mathrm{a} 25-31$ (listing health and strength as examples of partial goods).

174. Id. at $6.51140 \mathrm{~b} 26$.

175. See id. at $6.81142 \mathrm{a} 21-22$ (stating that deliberation can err either about the universal or the particular). On practical reason's emphasis on particulars in Aristotle's philosophy, see SHERMAN, FABRIC OF CHARACTER, supra note 83, at 1-12, 28-44; id. at 25-26 (arguing that orthos logos, the standard guiding the judgments of a person with practical wisdom, is incorrectly translated as "right rule" or "right principle," because it refers to the ability to make judgments based upon experience and an assessment of the particular aspects of the circumstances at hand, and not to a general rule to be applied).

176. On theoretical wisdom (sophia), see Aristotle, Nicomachean Ethics 6.7 114la16-20 (stating that theoretical wisdom must be made up of scientific knowledge and intuition (nous) because the wise man grasps first principles in addition to being able to draw conclusions from them); id. at 6.7 $1141 \mathrm{~b} 20$ (stating that theoretical wisdom must be the chief knowledge of the most honorable ohjccts). The former passage suggests that theoretical wisdom includes the apprehension of the foundations of scientific knowledge as well as the scientific reasoning process from principles.

177. Id. at 6.8 1142a25-26. Ostwald and Rackham both use the phrase "ultimate particulars." See CoOper, ReAson and Human GoOd IN ARISTOtLe, supra note 12, app. at 183-86 (discussing the meaning of eschaton). Aristotle also distinguishes between two types of political practical wisdom:

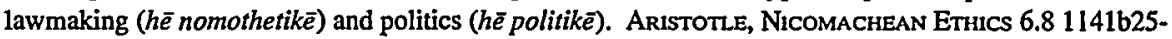
27. Lawmaking, which Aristotle calls "architectonic," is contrasted with politics, which deals with particulars. Because lawmaking provides prescriptions for action, it is ultimately directed toward particulars, although at a higher level of generality than political decisionmaking that is not legislative. See id. $6.111143 \mathrm{a} 34$ (arguing that all things that have to do with action deal with particulars and ultimates).

178. ARISTOTLE, NicomacheAN Ethics $6.71141 \mathrm{~b} 17-19$; see id. 6.11 1143b12-15 (maintaining that one should heed the statements and opinions of experienced older people, even if they are undemonstrated, as much as what has becn demonstrated).

179. Id. at $6.81141 \mathrm{~b} 32-34$. The Greek word for household management is ta oikonomia, which Rackham translates as "domestic economy."

180. See id. at 6.12 1144a30-31 (stating that practical wisdom cannot be acquired in the absence of virtue); id. at $6.131144 \mathrm{~b} 31-33$ (maintaining that based upon what was said, it is clear that it is impossible to be absolutely good without practical wisdom or to be practically wise without moral virtue); $i d$. at $6.131145 \mathrm{a} 2-3$ (stating that the person who possesses the one [virtue of] practical wisdom 
wisdom needs moral excellence because a person's virtue ensures the correctness of the goal of action, while practical wisdom ensures the correctness of what leads to the goal. ${ }^{181}$ Practical wisdom is impossible without

will have all [the virtues] as well). Aristotle makes the additional claim that moral excellence cannot exist without practical wisdom. Id. at $6.131144 \mathrm{~b} 17$ ([moral] excellence in the full sense cannot be attained without practical wisdom); id. at 1144b20-21 (there is no [noral] excellence without practical wisdom); id. at 1144b25-26 (m moral matters excellence is united with practical wisdom); id. at 10.8 1178a16-17 (practical wisdo1n and moral virtue are inseparable from one another). In contrast to practical wisdom, cleverness (deinotês) is the ability to reason well about the means to an end regardless of whether the end songht is noble or not. Id. at $6.121144 \mathrm{a} 23-27$.

In several places in Chapters $6.12-13$ the text says artete, which ineans simply "excellence" or "virtue." Nonetheless, consistent with most commentators, I have translated the term to mean "moral excellence" or "moral virtue." Elsewhere I use the phrases "moral excellence" or "moral virtue" to translate he ethike arete. For Aristotle, there is excellence(s) or virtue(s) (aretê) of the rational element of the soul in addition to the moral virtues or excellences of the nonrational element of the soul. See id. at 6.1 1139a11-15 (dividing the rational soul into a scientific aspect and a calculative or deliberative aspect, and announcing an imquiry into the excellence of each).

Most of the passages cited in this note suggest that the moral excellence inseparable from practical wisdom is a virtue of the nonrational element of the soul. See id. at 1.13 1102b13-14 (stating that there is an element of the soul that is nonrational (alogos), but it somehow participates in reason (metexousa .. p $\bar{e}$ logou )); id. at $1.131102 \mathrm{~b} 26-28$ (stating that the nonrational dimension of a continent person's soul obeys reason; the nonrational dimension of the self-restrained soul of the temperate and brave person listens to reason even more because it agrees with reason in everything); $i d$. at $1.131102 \mathrm{~b} 29-32$ (stating that the nonrational element of the soul shares in reason insofar as it both listens to reason and obeys it).

Elsewhere, however, Aristotle speaks as though desire for what is good exists in the rational element of the soul itself. See AristotLe, DE ANIMA 3.9 432b4-7 (asserting that it is an error to divide the soul into a rational and a nonrational part, with desire confined to the latter, since desire can be found in the rational as well as in the nonrational part). The last passage is important for the thesis of this Article because it conld mean that when practical reason is perfected, it somehow creates or assures the aecompanying moral excellence. This would give Aristotelian support for the legal theorists who focus on the deliberative aspect of democracy without separately addressing its moral fonndation. But see ARISTOTIE, Nicomachean ETHICs 3.2 1112a8-11 (noting that it seems wrong to equate choice with opinion because the people who make the best choices do not seem to be the same as those who hold the best opinions; in fact, sometimes people who hold snperior opinions choose what they should not, because of their bad character); id. at $2.41105 \mathrm{~b} 1-2$ (stating that knowledge is of little or no importance for possessing [moral] excellence).

The passage in Nicomachean Ethics 6.12 paraphrased in the text says that practical wisdom and moral excellence perfect a person's "function" (ergon). On this concept, see id. at $1.71097 \mathrm{~b} 24$ 1098a17 (asserting that if human beings have a function, their best state would seem to lie in their function and that the function of humans appears to be the active exercise of the rational sonl); STEPHEN R.L. Clark, Aristotle's Man: Speculations upon Aristotelian Anthropology 14-27 (1975); Nussbaum, Aristotle on Teleological Explanation, in ARIstotre's DE MotU ANIMALuU, supra note 172, app. at 100-06; Stephen Clark, The Use of 'Man's Function' in Aristotle, 82 Etrics 269 (1972).

181. ARIStotle, Nicomachean Ethics 6.12 1144a7-11; id. at 6.13 1145a4-6 (stating that choice will not be correct without practical wisdom and virtue, because the latter makes us attain the end, and the former is what leads to the end).

Classicists and philosophers are not agreed as to whether in these passages Aristotle limits practical wisdom to the discovery of means or envisions it as discerming both means and ends. See, e.g., NormaN O. Dafi, Practical Reason, Aristotle, and Weakness of the Will $93-99$ (1984) (arguing that reason coproduces motivation for action; by arriving at a conception of the human good, reason plays a central role in choosing what ends should be chosen); Troels EngBerg-Pedersen, ArIStotre's THEORY OF MORAL INSIGHT 183-84, 194-204, 211-21, $267-68$ (1983) (asserting that although practical wisdom grasps ends as well as means, because moral virtue arises independently and fixes the end of action, practical reason cannot change a person's desires in any profound way); IRWIN, ARISTOTLE's 
moral excellence because the end or the highest good will not appear as such to the person who lacks moral excellence. ${ }^{182}$ Thus practical reason cannot operate successfully in the absence of moral excellence. ${ }^{183}$ It is unclear from Aristotle's discussion whether practical wisdom is completely dependent on character for its "understanding" of the end or ultimate end of action, or whether bad character, in the form of appetites or desires for certain objects, interferes with a person's cognitive understanding of the correct end of action that is arrived at independently of moral virtue. ${ }^{184}$ Either way, practical reason will not ensure successful deliberation about worthy ends unless the person deliberating combines moral and practical rational excellence.

Aristotle's emphasis on the inseparability of practical wisdon and moral excellence can be traced to his teaching about the nature of choice. For Aristotle, all choice (prohairesis) involves both reason and a certain kind of desire; no one acts unless he first desires the end of the action. ${ }^{185} \mathrm{~A}$

FIRST PRINCIPLES, supra note 19, at 336 (arguing that, for Aristotle, people deliberate about which of their desires to satisfy, and not just about the means to satisfy their desires); NussBaum, Practical Syllogisms and Practical Science, in ARISTOTLE's DE MOTU ANIMALIUM, supra note 172, at 165, 170 \& n.13 (giving a brief overview of the literature and asserting that limiting deliberation to means, not ends, is based upon "misreading and mistranslation and should by now be buried"); SHERMAN, Fabric of ChARACTER, supra note 83, at 89-94 (asserting that deliberation is not exclusively confined to disceming means, since a person's understanding of the good life emerges froin, rather than antedates, the process of deliberation); William W. Fortenbaugh, Aristotle's Conception of Moral Virtue and Its Perceptive Role, in Transactions and Proceedings of the American Philological association 77 (1964) (arguing that moral virtue not only supplies motivation; it also makes the actor judge goals and concrete situations correctly); 2 RENE A. GAUTHIER \& JEAN Y. JOLIF, L'ÉTHIQUE Á NicomaQUB 577 (1959) (arguing that in these passages Aristotle really means that practical reason grasps the end of action and moral virtue supports the insights of practical reason by controlling appetites); T.H. 1rwin, The Structure of Aristotelian Happiness, 101 ETHICs 382, 388 (1991) (review essay) (stating that Aristotle believed deliberation diseerns means that are theinselves constitutive of the end, and not merely instrumental to it).

For an overview of both sides of the question, see DaHL, Practical Reason, ARistotle, and WEAKNESS OF THE WIL, supra, at 37-60, 89-92, 227-36 (arguing that practical reason has a role in the apprehension and acquisition of ends and explaining how practical reason arrives at ends through induction); id. at 74-89 (presenting the view that practical reason discerns only the means); id. at 4-5 (summarizing the scholarly literature on both sides of the question). For a thoughtful explanation of what it means to say that character or moral virtue supplies the end of action, see SHERMAN, FABric of ChARACTER, supra note 83, at 44-47 (arguing that emotions enable people to understand general moral precepts and apply thein to specific situations as well as to see particular facts that would otherwise go unnoticed). On Sherman's interpretation, character does not supply ends by making people instinctively disposed to act in a certain fashion; rather it enhances their cognitive abilities with respect to ends.

182. ARISTOTLE, Nicomachean Ethics 6.12 1144a34-37.

183. See id. at $10.81178 \mathrm{al6}-19$ (stating that practical wisdom is inseparable from the virtue of character, just as the virtue of character is inseparable from practical wisdom, since the principles of practical wisdom are in accordance with the moral virtues and correctness in morals is in accordance with practical wisdom).

184. For ways in which desire might inpair cognition, see infra notes $185-88$ and accompanying text (explaining Aristotle's thcory of choice) and notes $189-92$ and accompanying text (summarizing Aristotle's discussion of weakness of the will).

185. Aristotle, Nicomachean Ethics 3.3 1113a9-12 (describing ehoice as desiring an object after deliberation about it); id. at $6.21139 \mathrm{~b} 4-5$ (concluding that choice is either "thought related to desire" or "desire related to thought") (Rackham trans.). Aristotle reserves the term "wish" (boulësis) 
person's ability to choose the correct action thus depends on both desiring the action and believing it to be right. ${ }^{186}$ Moral virtue or excellence is the source of a person's desire for right goals. ${ }^{187}$ As a result, Aristotle believes that neither children, who lack reason, nor morally weak people, who lack right desires, act from choice. ${ }^{188}$

It is unclear, however, whether Aristotle believes that a person who does wrong when the person "knows" what is right actually recognizes that the action is wrong at the very moment of actimg. Aristotle addresses this issue during his discussion of the phenomenon of weakness of the will (akrasia). ${ }^{189}$ Some commentators believe that Aristotle's description of akrasia covers the situation where a person actually knows that it is wrong to engage in a particular action, but nevertheless acts because of an overpowering desire for the object of that action. ${ }^{190}$ Thus understood, the doctrine of akrasia implies that people may have a correct cognitive perception of how to behave, but certain character traits may cause them to disregard what they know to be right. In contrast, some commentators interpret Aristotle as suggesting that desire or appetite somehow distorts the cognitive perception or knowledge of akratic people. ${ }^{191}$ Thus, despite having knowledge that an action is wrong before acting, at the time of the act, the akratic person's perceptions are blurred, and he lacks complete and actual knowledge of the wrong. ${ }^{192}$ According to the second view, akrasia never actually exists because a person who acts contrary to his beliefs does not possess a sufficiently concrete and precise knowledge of the correct way to act at the very moment of acting.

for occasions when a person desires a good end. Id. at $3.21111 \mathrm{~b} 17-18,3.41113 \mathrm{a} 15-16$. For a discussion of rational agency, including the concept of wish, see IRWIN, ARISTOTLE's FIRST PRINCIPLES, supra note 19 , at $336-37$.

186. Aristotle's observations in Nicomachean Ethics about the nature of choice can theinselves be traced to his views about the nature of change and motion, which are discussed in his works on biology and on the soul. See AristotLe, De ANIMA 3.10 433a9-433b1 (observing that although desire and thought both appear capable of initiating inovement, thought never causes movement in the absence of desire). Imagination and desire can also cause movement, but for Aristotle imagination is not part of the rational element of the soul. See id. at 3.3 427b15-23; cf. id. at 3.10 433a9-10 (classifying imagination provisionally as a kind of thought).

187. See ARISTOtLe, Nicomachean Ethics 6.2 1139a22-26.

188. Id. at $3.21111 \mathrm{~b} 12-15$. Aristotle distinguishes choice from volition; children and animals may act voluntarily, but not from choice. Id. at 3.2. 1111b8-9.

189. Id. hk. 7.

190. See J.L. Ackrill, Aristotle's Ethics $32-33$ (1973); David Charles, Aristotle's PhILosophy of Action 162-67, 176 (1984); $c f$. Dahi, Practical Reason, Aristotle, and Weakness OF THE WILL, supra note 181, at 188-204 (conceding that the akratic person does not have the most complete form of knowledge, yet arguing that this person does know what is right at the moment that he acts contrary to that knowledge).

191. See David Wiggins, Weakness of Will, Commensurability, and the Objects of Deliberation and Desire, 79 Proc. Aristotelian Soc'y (n.s.) 251 (1979).

192. See Richard Robinson, Aristotle on Akrasia, in 2 ARTICLES on ARISTOTLE: ETHICS AND Polmics, supra note 62, at 79, 79-84; Gerasinos Santas, Aristotle on Practical Inference, the Explanation of Action, and Akrasia, 14 PhroNesis 162 (1969); see also DAHL, PRACTICAL ReAson, ARISTOTLE, AND WEAKNESS OF THE WILL, supra note 181, at 139-218. 
Common to both interpretations is a portrait of a person who fails to act as he thinks he ought to act because the rational and nonrational elements of his soul are at war with one another. ${ }^{193}$ Thus, for the purpose of this Article, it is unnecessary to resolve the philosophic puzzle in Aristotle's account of akratic behavior. Regardless of the precise character of the akratic person's ignorance, practical reason cannot perform its proper function in the absence of certain moral character traits. In terms of contemporary aspirations for a more deliberative democracy, Aristotle's discussions regarding choice and weakness of the will teach that without good character, a person's ability either to be persuaded by rational argument or to be motivated by it to act will be impaired.

\section{The Development of Good Character}

For Aristotle, the willingness to behave in a certain fashion does not emanate directly or exclusively from a person's rational awareness or understanding. Aristotle's teaching concerning the nature of action makes clear that the reason a person can hold correct opinions and still choose wrongly is the absence of good character. The practical consequence of his insight is that to influence people's conduct, it is necessary both to address their moral education and to persuade them of the correctness of a course of action.

Aristotle observes that repetitive conduct is essential to the development of good character. Although people have natural inclinations or tendencies to act in one or another fashion, ${ }^{194}$ moral excellence arises, in part, as a result of habituation and thus cannot be equated with the natural tendency. ${ }^{195}$ Habits, in turn, arise as a result of repetitive conduct. ${ }^{196}$ In

193. See Aristotle, Nicomachean Ethics 1.13 1102b14-18.

194. Id. at $6.131144 \mathrm{~b} 4-6$.

195. Id. at 2.1 1103a17-19. Because we have a natural capacity to form such habits, moral excellence is not contrary to nature even though it is not simply natural cither. Id. at 2.1 1103a23-24. On "natural virtue," see KraUt, ARISTOTLE AND THE HuMAN Good, supra note 86, at 247-49; J.M. Finnis, Legal Enforcement of "Duties to Oneself": Kant v. Neo-Kantians, 87 ColuM. L. REv. 433, 454 (1987) (noting that Aristotle and Aquinas represent the view that people prone to bad conduct can, through habituation, come to choose good conduct willingly).

196. Aristotle, Nicomachean Ethics 2.1 1103a30-1103b1, 2.1 1103b14-24, 2.2 1104a33; see id. at $3.51114 \mathrm{a} 9-11$ (observing that only someone completely devoid of sense can fail to know that states of character [arise from activity]); ARISTOTLE, RHETORIC $1.101369 \mathrm{~b} 6$ (stating that "[a]cts are done from habit which men do because they have often done them before") (Roberts trans.). That habits arise mechanically from repetitive conduct is the traditional interpretation of Aristotle's moral theory. See Peter Simpson, Contemporary Virtue Ethics and Aristotle, 45 Rev. Metaphysics 503, 515 (1992) (noting that for Aristotle children's passions are first controlled by habituation, not by teaching or appeals to reason). For a contrary view, see SHERMAn, FABric of Character, supra note 83, at 157-99 (noting the Aristotelian texts that support the traditional view, but arguing that a developmental, rational model of habituation is consistent with other Aristotelian texts, especially those that refine the simplistic division of the soul into rational (to logon) and nonrational (to alogon), those that depict children's rational capacity as evolving over an entire life, and those that describe the intentional and cognitive components of emotion); M.F. Burnyeat, Aristotle on Learning to be Good, in Essays on ARIsTorte's ETHICS, supra note 79, at $69,73-77$ (arguing that habituation has a cognitive component that enables the 
Aristotle's view, people must engage in repeated acts that exemplify a particular character before they develop that character themselves. Thus, a person becomes self-controlled only by acting in a self-controlled manner over a period of time. ${ }^{197}$ In contemporary terms, this means that at the outset a person engages in acts of a certain kind even though she has not yet internalized the character trait or quality of soul corresponding to those acts. Through repetition of those acts, she gradually acquires the corresponding habit and, thus, paves the way for the moral excellence corresponding to the character of those acts. ${ }^{198}$

Aristotle believed that the repetitive conduct that forms habits and builds character is traceable, directly or indirectly, to the laws. ${ }^{199}$ Arguments alone ordinarily do not make people good because, prior to habituation in good or noble conduct, people are motivated to act primarily in pursuit of what is pleasant and avoidance of what is painful. ${ }^{200}$ Appealing to the minds of such people througl arguments about the good is thus unlikely to succeed in many, perhaps most, cases. Moreover, the longer people habitually live a life ruled by passion, the harder it will be to change their character througl argument. ${ }^{201}$ According to Aristotle, a person who is habituated to a life ruled by passion will not likely listen to arguments to change his mind about how to live, or else he would not understand them if

student to acquire a mature understanding of why his habits are correct); Richard Sorabji, Aristotle on the Role of Intellect in Virtue, in EssaYs ON ARISTOTzE's ETrics, supra note 79, at 201, 214-18 (arguing that habituation presupposes reason as well as desire and that virtue presupposes teaching as well as habit).

197. Aristotle, Nicomachean Ethics 2.2 1103a31-b2.

198. Several passages in the Nicomachean Ethics create the impression that inoral virtue is a product of habit alone. However, other passages state that there is no moral virtue without practical wisdom, the latter being the excellence of the practical rational dimension of the soul. The Iatter passages suggest that habituation is the necessary but not sufficient condition of moral virtue or excellence. See T.H. Irwin, Aristotle on Reason, Desire, and Virtue, 72 J. PHL. 567, 576 (1975) (arguing that habituation and training provide only "promising raw material" that requires practical wisdom to becoune virtue); infra Part V.A.

Some contemporary theorists also emphasize the importance of action for acquiring character traits. See Goldfarb, Theory-Practice Spiral, supra note 7, at 1662-65 (arguing that because repetitive action is necessary for developing good character and moral understanding, clinical legal education is indispensable for developing a lawyer's ethical respousibility); Luban, Epistemology and Moral Education, supra note 7, at 650-51 (arguing that experience in acting "is an epistemological precondition of knowing moral principles").

199. Aristotle, Nicomachean Etrics $2.11103 \mathrm{~b} 4-5$ (stating that the lawgiver makes the citizens good by habituating thein and that habituation makes the difference between a good regime and a bad one); id. at $10.91179 \mathrm{~b} 28-1180 \mathrm{a} 24,3.11109 \mathrm{~b} 34$.

200. Id, at $10.91179 \mathrm{~b} 4-14$.

201. Id. at $10.91179 \mathrm{~b} 18$. Aristotle does not deny that people can sometimes change their character after it is formed. But the process would, in his opinion, be slow and difficult, even in those cases where improvement is possible. See Aristotre, Categories 13a23-31. But see Aristotle, Nicomachean ETHCs 3.51114 a 15-22 (suggesting that once people become self-indulgent or unjust voluntarily, it will be inpossible for them to change). On the secming contradiction between this passage, denying the possibility of change, and the passage in the Categories that envisions some change, see William Bondeson, Aristotle on Responsibility for One's Character and the Possibility of Character Change, 19 Phronesis 59, 60-62 (1974). 
he did listen. ${ }^{202}$ Thus, in the first instance, ${ }^{203}$ the repetitive actions that build good habits must be "commanded." This occurs through proper upbringing and education, both of which typically derive their nature and legitimacy from the government and the law. Government and law, according to Aristotle, form the "regime" or character of a political community as a whole. Aristotle was of the view, however, that although good character originates im habit, it inust ultimately be grounded in understanding.

If the government does not have as one of its goals the development of good character, Aristotle appears to envision the possibility that individuals can fill the void in relation to their children and friends. ${ }^{204}$ This private solution to the developinent of good character, however, is more likely to succeed if private educators are acquainted with the art of lawmaking. ${ }^{205}$ In other words, it is possible to replicate the lawgiver's concern for good character and the well-being of the community as a whole at the level of individuals who are theinselves committed to these objectives. However, to make "private politics" work, it is useful for these individuals to immerse theinselves in the proper or public art of politics.

\section{IV \\ The Consequences of Aristotle's IDEAs for the Contemporary Deliberative Project}

If accepted, Aristotle's views on the inseparability of inoral excellence and practical reason have important consequences for the various visions of deliberative democracy espoused by contemporary legal theorists. The conclusion of Part II was that contemporary legal theorists with repubhican concerns share a faith in the ability of rational persuasion to induce people to enter into the deliberative dialogue, to participate in good faith with a will-

202. ARistotle, Nicomachean Ethics $10.91179 \mathrm{~b} 26$.

203. I say "in the first instance" because Aristotle believed that moral actions accompanied by understanding were both possible and desirable for adults. See infra Part V.A.

204. Aristotle, Nicomachean Ethics $10.91180 \mathrm{a} 29-32$. This possibility presupposes that some people of good moral character can exist in the absence of good laws, although Aristotle does not explicitly address how such people would become good in the first place. His views on natural virtue suggest sometimes people are naturally inclined to good character and then have their natural tendencies reinforced through chance or private traditions, the latter (presumptively) traceable to good government at some point in the past. By hypothesis, the first founder of a government that enacted laws with a view to developing the citizens' good character must have possessed good character that was not itself a product of good laws. The passage cited and the idea of the first founder of good laws thus both suggest a significant qualification to the absolute necessity of good laws for the development of moral excellence.

205. Id. at $10.91180 \mathrm{a} 33-1181 \mathrm{~b} 24$. In particular, Aristotle recommends a study of politics and political institutions such as is contained in his Politics. On this passage, see Christopher Rowe, Aims and Methods in Aristotle's Politics, in A CoMpanion to ARIstotre's Poltrics, supra note 12, at 57, 74 (suggesting that Aristotle recommends leaming the art of politics from him rather than from politicians since the latter rarely pay attention to upbringing); see also Nichols, Crrzzens AND STATESMEN, supra note 20 , at 7 ("By calling his own inquiry 'a kind of politike,' Aristotle suggests that his own political philosophy entails political activity or statesınanship."). 
ingness to learn froin other participants, and to abide by the outcoines eveu when these conflict with their own deeply held convictions. In contrast, one of the lessons of the Aristotelian texts surveyed in Part III is that persuasion alone will not necessarily affect conduct. Differently put, reason is only one part of persuasion. If Aristotle is correct, contemporary legal theorists inust learn to influence the hearts as well as the minds of citizeus for deliberative democracy to be viable.

What would this approach look like? At a minimum, contenporary legal theorists would have to investigate what types of character traits are presupposed by the deliberative political enterprise they envision and what types of legislation, social policy, and family practices are most likely to achieve them.

One reason theorists are reluctant to address such issues is the potentially coercive or totalitarian implications. ${ }^{206}$ Classical republican thought includes a theory of civic virtue that ranges from unappealing to terrifying for many contemporary legal theorists. Three aspects of classical civic virtue inake it especially objectionable. First, its goal is creating, or reinforcing, a hounogenous citizenry. This aspiration is at odds with contemporary views of the importance of pluralism and diversity. ${ }^{207}$ Second, many of the noral character traits celebrated by classic republicanism are questionable, if not distasteful, to some. Those that immediately come to mind are the more military and religious character traits. ${ }^{208}$ Third, to achieve the homogeneity and predictability of civic virtue considered essential by classical republican theorists, it is assumed that moral precepts should be inculcated at an early age by nonrational means (such as an incentive structure of rewards and punishments or through the example of authority figures). ${ }^{209}$ Such methods cut against the modern temper, which prefers that all aspects of human life be as voluntary as possible. According to this contemporary view, learning by rote or through fear of punishment is not only coercive, it fails to respect the human capacity for autonomy and is thus inferior to learning based upon rational persuasion. ${ }^{210}$

If, however, Aristotle is correct about the psychology of reason and reasoning, then coutemporary legal thought is presented with a dilemina.

206. Contrast Stephen Gardbaum's challenge to the liberal argument that the alternatives to state neutrality are coercive. Gardbaum argues that it is no more coercive for the state to take a position on conceptions of the good life than it is for a political majority to dictate to the minority on any other issue. He notes further that, as neutralists themselves concede, not all uses of coercion are objectionable and that neutralists have not met their burden of demonstrating that the coerciveness associated with state action in moral matters is objectionable. Stephen A. Gardbaum, Why the Liberal State Can Promote Moral Ideals After All, 104 HaRv. L. Rev. 1350, 1366-69 (1991).

207. Michelman, Traces of Self-Government, supra note 14, at 21, 23, 29; see Solum, Virtues and Vices, supra note 14, at 113. See infra Part V.B for a response to this objection based upon Aristotelian texts.

208. Sunstein, Beyond the Republican Revival, supra note 14, at 1564-65.

209. Solum, Virtues and Voices, supra note 14, at 119-20.

210. See infra Part V.A for a response to this objection based upon Aristotelian texts. 
Either a more deliberative politics will remain largely a theoretical concept except, perhaps, in rare instances where a population is spontaneously suited to the deliberative enterprise, or contemporary republican theorists must reassess their suspicion of moral education.

Some of the authors discussed in this Article may well have reached the former conclusion; hence their emphasis on the judiciary as the locus of deliberative activity. ${ }^{211}$ Even if it is unreasonable to expect members of the population in general to have the intellectual and character traits conducive to deliberative decisionmaking, it may nonetheless be reasonable to expect members of the judiciary to display such traits, for example, as a byproduct of the judicial selection process.

Alternatively, my contention is that contemporary legal theorists should reassess the possibilities for moral education. The most promising basis for such a reassessment is the possibility that the civic virtue presupposed by a deliberative deinocracy differs from the civic virtue presupposed by classical republican theory in ways that would make contemporary civic virtue less objectionable than classical civic virtue. ${ }^{212}$ For example, the classical idea of civic virtue is often presented as predicated on an aristocratic view of political life. In contrast, contemporary civic virtue would be based upon a liberal and/or democratic view of politics, in particular, a view that takes as its starting point the political equality of human beings. Similarly, the classical idea presupposes a large degree of homogeneity among citizens, whereas contemporary theorists frequently argue for the superiority of heterogeneity and difference. The classical idea also glorifies military virtues, whereas the contemporary version would recognize the necessity of military virtues, but would relegate them to a lesser role in human development. Concomitantly, the contemporary version would elevate other virtues recognized by classical theorists or introduce new virtues more responsive to contemporary conditions.

The question raised by a reassessment of moral education is whether we can formulate a coherent, contemporary version of civic virtue that is deduced from the character traits useful or necessary for deliberative dialogue. What would such character traits look like? Although the purpose

211. See, e.g., Perry, MoraltTy, Polmics, ANd Law, supra note 34, at 121-79; Michelman, Traces of Self-Government, supra note 14, at 74-77. On this aspect of Michelman's argument, see Kahn, Community in Contemporary Constitutional Theory, supra note 97, at 33-37. Sunstein locates the deliberative function in both the courts and nonjudicial bodies. See Sunstein, Beyond the Republic Revival, supra note 14 , at 1576.

212. See, e.g., William A. Galston, Liberal Purposes: Goods, Virtues, and Diverstty in the Liberal State 220-21 (1991) [hereinafter William A. Galston, Liberal Purposes] (arguing that the liberal virtues "demand less self-discipline and sacrifice than do the virtues of classical antiquity, of civic republicanism, or of Christianity"; at the same time, they are not "reducible to self-interest, even self-interest 'rightly understood.'"); William A. Galston, The Use and Abuse of the Classics in American Constitutionalism, 66 CHI.-KENT L. REv. 47, 64-65 (1990) (arguing that we should turn to classical political philosophy for clarification of certain problems, but that contemporary civic virtue must be relative to the principles of contemporary, rather than classical, regimes). 
of this Article is less to answer this question than to put it on the agenda of legal theorists who advocate a more deliberative political commumty, two general categories of character traits nonetheless suggest themselves as candidates for fruitful inquiry. First, there are those character traits that are observable in people who are deliberative in their own lives: moderation in acquisitiveness and certain kinds of ambition; purposefulness; carefulness; attention to detail; perseverance; the willingness to defer immediate gratification; confidence that progress is possible and that human action can shape events; respect for, although not slavishness to, rules and traditions; and the ability to distinguish the speaker from the speech in order to take seriously ideas and arguments regardless of one's degree of affinity with their advocates. The second category would consist of character traits that tend to create or reinforce our bonds with others: loyalty to others; concern about and responsibility for the well-being of others; and honesty in our dealings with others.

In soine respects, the desirability of such character traits is so obvious that these suggestions may appear trite. What is not obvious is that as legal theorists, we have an obligation to take seriously the Aristotelian imsight that practical reason needs good character as its ally, rather than to gainsay its validity based solely upon our moderu predilections and without the benefit of the type of sympathetic hearing that we expect participants in the deliberative process to display. Also not obvious is the possibility that, if Aristotle is even partially correct, we have an affirmative obligation first to identify and then to promote those character traits that are conducive to a more deliberative society. Taking this obligation seriously is especially important because of the visceral sense many people have that public institutions should remain as neutral as possible toward individual notions of moral worth.

The work currently being done in disciplines related to legal theory may offer republican-oriented legal theorists promising avenues of inquiry. In particular, several political theorists and moral philosophers have put forward theories developing a notion of citizen virtue within the context of a liberal, dennocratic, and pluralist society. ${ }^{213}$ Some of these theories advocate a political community that affirmatively encourages the development of a minimal list of character traits in its citizens, such as rationality and

213. For an overview of the efforts of some recent theorists to develop a liberal or democratic political theory based upon Aristotle's moral philosophy, see John R. Wallach, Contemporary Aristotelianism, 20 POL. THEORY 613 (1992) (summarizing major recent developments and criticizing those Aristotelians who marginalize the political dimension of Aristotle's philosophy by treating his moral philosophy as independent of his political philosophy); see also Ronald Beiner, The Classical Method of Political Science and its Relation to the Study of Contemporary Politics, 19 Gov'T \& OpPosrrion 471 (1984) (arguing that contemporary political science is mistaken in viewing itself as value free and as independent of and instrumental to moral philosophy, and advocating a return to classical philosophy in these areas); Simpson, Contemporary Virtue Ethics and Aristotle, supra note 196 (criticizing contemporary neo-Aristotelians for ignoring the Politics, which describes the ways to bring about the active exercise of the virtues discussed in the Nicomachean Ethics). 
equality, while otherwise leaving people free to pursue their private conceptions of the good as much as possible. A second group of theories understands the goal of a deinocratic politics to be inore heavily value laden than the minimalist theorists. According to the latter view, a democratic political community should involve itself in the moral education of its citizens to a significant degree.

An illustration of the former category is the work of Stephen Macedo, for whom liberal democracy at its best will reflect the foundational principle of "reasoned self-government." $214 \mathrm{He}$ argues that, to this end, liberal political commurities promote, and should promote, character traits hinked to the twin primciples of respect for people's autonomy and the importance of public justifications for political decisions ("public reasonableness"). ${ }^{215}$ Macedo argues that these character traits, called "liberal virtues," are the types of excellence appropriate to communities that affirmatively promote the twin principles and are conducive to flourishing in liberal societies. ${ }^{216}$ Macedo's liberal virtues include such traits as syinpathy for the ideas and aspirations of others; reflective attributes such as self-examination, selfcriticism, and experimentation; openness to strangers; self-1nastery and selfcontrol; "executive" virtues such as initiative, independence, resolve, perseverance, diligence, and patience; devotion to a pubhic morality; moderation; and the traditional liberal candidates-tolerance and respect for others. ${ }^{217}$ While liberal communities should cultivate diversity, they should accoinplish this goal, not through neutrality, but by directly championing the moral character traits basic to a reflective and cooperative citizenry.

Macedo's theory differs froin that of more individualistic liberals in that he makes a sharp distinction between "a community flourishing in a distinctively liberal way . . . [and] a community simply governed by liberal

214. Stephen Macedo, Liberal Virtues: Cittzenship, Virtue, and Community in Liberal Constitutionalism 200 (1990) [hereinafter Macedo, Liberal VirTUEs].

215. Id. at $40-45$. The "moral core" of public reasonableness is a commitment to public justification. Id. at 40-41, 45-50. Public justification is both an instrumental and an intrinsic good because being a self-critical reason-giver is a good, and not just a liberal, way to live. Id. at 59. For Macedo's detailing of the requirements for autonomy, see id. at 203-53. Macedo rejects the concept of autonomy understood as freedom to choose without any restraints (which he calls "antarchy") in favor of "liberal situated autonomy." Id. at 214-17,225-26. Central to his concept of autonomy is the manner in which people do what they do, e.g., self-critically or not, actively or not, and low their activities harmonize with their larger life plans. Id. at 216-23, 232-33. Autonomy, in other words, "is not a complete ideal." Id. at 233.

216. Id. at 4, 254-86. The liberal virtues are not, however, legal duties; it is sufficient that they constitute part of the explicit but voluntary ideology of the liberal state. See id. at 4; see also Stcphen Macedo, Charting Liberal Virtues, in VIRTUE: Nomos XXXIV 204, 213 (John W. Chapman \& William A. Galston eds., 1992). For other accounts of liberal virtues, see William A. Galston, Liberal Virtues, 82 Am. Pol. Scr. Rev. 1277 (1988); David A. Strauss, The Liberal Virtues, in VIRTUE: Nomos XXXIV, supra, at 197.

217. MACEDo, Liberal Virtues, supra note 214, at 2, 69-73, 265-83. According to one commentator, Macedo's liberal virtues are too weak and superficial to create a genuine community. See John Tomasi, Book Review, 102 Etrics 397, 398 (1992). 
justice."218 In the former, "citizens do not simply act in outward conformity with liberal norms, they affirm liberal justice as a supreme moral commitment." 219 He rejects the tendency of liberals "to minimize what they stand for and to evade their ultimate commitments."220 However, while linking liberalism to substantive conceptions of political morality, Macedo rejects the ideal of a single, authoritative conception of the good life. ${ }^{221}$

Illustrative of liberal theories with a more value-laden orientation is the work of Amy Gutmann, who charts a course for education im a democratic society that may well appeal to republican-oriented and liberal theorists alike. In concert with the former, Gutmann argues that the democratic goal of self-government does not imply a neutral state ${ }^{222}$ and that democratic education should seek to imstill in children "the kind of character

218. MaCedo, LIBERAL VIRTUES, supra note 214, at 266.

219. Id. at 255; see Charles E. Larmore, Patterns of Moral ComplextTy (1987). In elaborating a political alternative to either a liberal atomistic society or a communitarian organic society, Larmore accepts a variant of the communitarian belief that our ties to the larger community are a constitutive part of our humanity. Id. at 15, 96; Larmore, Political Liberalism, supra note 163, at 346. At the same time, lie believes that the values that society should affirmatively promote are the "neutral values" that make possible the pursuit of most, if not all, conceptions of the good. Such neutral values might, however, favor certain ways of life over others, or rule out certain ways of life. LARMORE, PatTerns of Moral Complextry, supra, at 43-44. His theory is ultinuately based upon maintaining a separation between public or political values and private or personal values. See id. at ix-x, 40-90; Larmore, Political Liberalism, supra note 163, at 345-46. This resembles the claim made by some that liberalism is a political, not a metaphysical, doctrine. See Buchanan, Assessing the Communitarian Critique of Liberalism, supra note 16, at 853-54 (distinguishing between liberalism as a theory of self, human nature, or society, and liberalism as a minimal political philosoply); John Rawls, Justice As Fairness: Political Not Metaphysical, 14 PHrl. \& PuB. Afr. 223, 230-31 (1985). But see Gutmann, Communitarian Critics of Liberalism, supra note 16, at 313-14 (stating that Rawls' theory is not compatible with all metapliysical theories; his principles of justice preclude theories of the self as radically situated).

220. MACEDo, LiBeral VIRTuEs, supra note 214, at 50-51; see id. at 208 (arguing that respect for the autonomy of others does not "imply" that nothing can be said about what is good as such or good for all men); id. at 216 (asserting that "liberals need not, lowever, regard all choices as equally valuable or as equally compatible with a liberal form of excellence").

221. Id. at 207; see id. at 208-09 (noting that in his political theory, "riglts normally take priority over the collective pursuit of common goods," although also mamtaining it is important "that many of those same rights advance certain valued goals ... and contribute to good character traits"); id. at 5 (refusing to base his account of liberal virtues on a "full theory of the good latent in liberal practice"" (quoting William Galston, Defending Liberalism, 76 AM. PoL. Scr. Rev. 621, 627 (1982))); id. at 204 (celebrating autonomy as "something more than one personal ideal annong others").

222. Gutmann, Democratic EduCATION, supra note 97, at 34-37. Gutmann also argues that as a descriptive matter, liberalism is not neutral to the extent that many of its proponents claim. Id. at 34,5355 (rejecting the claim of democratic educators that no correct set of values is being taught and arguing that the spccific values of rationality, justice, creativity, and equality are typically taught); see WILLAM A. Galston, Liberal Purposes, supra note 212, at 252-54 (arguing that a highly pluralistic soeiety consistent with mainstream visions of liberalism presupposes not neutrality but a distinctive conception of the good); West, Liberalism Rediscovered, supra note 15, at 674. West links the liberal celebration of autonomy and neutrality with regard to conceptions of the good to the assumption of masculine jurisprudence, which at the deepest level views human beings as essentially separate from one another. West, Jurisprudence and Gender, supra note 135, at 5-9. 
conducive to democratic sovereignty."223 In other words, the state must act affirmatively to inculcate certain values and virtues. In contrast to classical civic republicans, Gutmann would limit the state to encouraging only those virtues that enable citizens to be deliberative and to engage in the collective sliapimg of their society. Although correct outcomes are important, she views them as less miportant for democratic principles than the process of self-government (understood as constrained by democratic values and not merely as popular consensus). ${ }^{224}$ Gutmann concludes that the central democratic constraints on educational institutions and policies should be a prohibition against discrimination im educational opportunities and a charge to create citizens capable of deliberating critically about alternative ways of life, with a view to living a good or morally desirable life as understood by a democratic and deliberative citizenry. ${ }^{225}$ In short, neither abstract notions of the good life nor mere popular (but unreflective) consensus should govern politics and define education to citizenship.

Nonetheless, any moral agenda promoted nationally and implemented, for exainple in scliools or other forms of public education, may signal an unacceptable degree of coerciveness for some liberals. One response to this concern constitutes a second possible basis for reassessing contemporary suspicions of moral education. The liberal agenda, it may be argued, is itself nonneutral: for exainple, it excludes subjects on the grounds that they are at odds with the liberal temper. ${ }^{226}$ The exclusion of these subjects can itself be viewed as an exercise in coerciveness of significant proportions. The question thus is not whether contemporary legal theory will tolerate coercive or exclusionary doctrines and practices, but rather which coercive or exclusionary doctrines and practices we as a nation consider preferable. ${ }^{227}$ The reluctance anong contemporary legal theorists to consider the

223. Gutmann, Democratic Education, supra note 97, at 41. In particular, the idea of democracy implies limits to the ways of life citizens can choose; it precludes, among other things, policies that would hinder or prevent generations of citizens from participating "intelligently as adults in the political processes that shape their society." Id. at xi, 95-96.

224. Id. at 96-97; see id. at $36,44-46$.

225. Id. at 43-46 (maintaining that education should enable people to cloose good lives and not just to choose to express their autonomy); id. at 55-56 (stating that all moral values are not equal; some are simply wrong). She envisions character traits such as honesty, religious toleration, mutual respect for persons, and industriousness as standards for educators to inculcate in their students. See id. at 37-38, 44.

226. Many political theorists deny the identification of liberalism with neutrality. See, e.g., MACEDO, LIBERAL VIRTUES, supra note 214, at 257-63 (denying that liberal legal institutions can or sliould be neutral with regard to conceptions of the good life); Beiner, What's the Matter with Liberalism?, supra note 15, at 45-46 (arguing that liberalism puts freedom ahead of perfection because of its belief that "choice is the essence of personhood"); Gardbaum, Why the Liberal State Can Promote Moral Ideals After All, supra notc 206, at 1366-69 (denying that state-neutrality describes liberalism as an empirical matter and argumg on a normative level that liberalism should not cede all public concern for substantive values to its critics).

227. See Gutmann, Democratic Education, supra note 97, at 36-40 (arguing that an education designed to maximize citizens' freedom may undermine the ability to pursue other ways of life, especially a life of virtue). 
possible moral conditions of the deliberative enterprise is thus unreflective insofar as it exaggerates the coerciveness of alternative theoretical approaches, while ignoring or understating the coerciveness of its own teachings. 228

Finally, a meaningful distinction can be made between moral education and moral fanaticism. This msight promises a third basis for reassessing contemporary suspicions of moral education. Here, too, Aristotle's writings are instructive. Aristotle understood good character as dependent upon the fornation of habits, and, to that extent, it may not appear to be rational or voluntary. ${ }^{229}$ If, however, the character traits presupposed by deliberative democracy are fashioned in the first place to create a more thoughtful citizenry, it is possible that the imitial "coercive" education of children can be superseded by a subsequent deliberative re-examination by adults that will confirm or repudiate their initial education. Hence, conduct or attitudes that began as mindless can becoine mindful. The likelihood of this outcome will depend less on the existence of moral education than on its character. The varieties of religious education afford a useful analogy. Although revealed religions take the correctness of a core body of moral and legal precepts as a given, such religions, or their denominations or sects, vary widely in their openness to rational inquiry on the part of ordinary adherents, clergy, or theologians. ${ }^{230}$

In short, it is possible that the perils of moral education have been overstated. If so, the real issue is one of balancing the advantages and disadvantages of putting the purposeful development of character traits supportive of a deliberative way of life on the public agenda, rather than reserving it for wholly private mitiatives. Part V of this Article contributes to the balancing process by exploring more fully several of the most dis-

228. See Gutmann, Communitarian Critics of Liberalism, supra note 16, at 316-18 (criticizing the tyranny of contemporary theorists who portray the universe in dualistic terms).

229. Note that habit is the necessary, but not sufficient, condition of good character. See SHERMAN, FABRIC of Character, supra note 83, at $155-99$ (rejecting the view that for Aristotle habituation is mechanical and nonrational and arguing instead that Aristotle's works embody a developmental theory of habituation that cultivates deliberative capacities); supra note 196 and infra Part V.A.

230. See Joseph Schacht, The Origins of MuHammadan JuRISPRudence 128-30, 253-59 (1950) (describing the traditionists in Islam, who are hostile to human reasoning, and the Mu'tazila, the most rationalist school of Islamic religious thought); JosEph SCHACHT, AN INTRODUCTION To ISLAMIC LAw 69-75 (1966) (describing the decline of independent or systematic reasoning in Islamic law); BERNARD G. WeISS, The SEARCh For God's LAw: ISLAMIC JuRISPRUdENCE IN THE WrITINGS OF SAYF AL-Din AL$\bar{A}$ ADI 18-23 (1992) (contrasting the speculative trend in Islamic jurisprudence with the traditionoriented trend); Christianity, 16 NEw Encyclopedia Britannica, Macropaedia 272, 302-03 (15th ed. 1986) (discussing historical tension between intellectualisin and anti-intellectualism in Christian theology); Judaism, 22 New EnCYClopedia Britannica, Macropaedia 402, 454-62 (15th ed. 1986) (discussing Jewish philosophy and noting the differing levels of importance that reason has taken in the work of Jewish theologians); Knowledge aud Ignorance, 8 ENCYCLOPEDIA OF RELIGION 343 (Mircea Eliade ed., 1987) (providing an historical perspective on the views of various religious groups on the relation of reason to religion); Reasoning, Theological, 12 NEw CAtHolic EnCYCLOPEDIA 121 (1967) ("W]hereas Catholic theologians assert the legitimacy of an intelligence of revelation by means of truths of reason, Protestant theologians in the great majority deny it."). 
turbing concerns put forward by those opposed to publicly sponsored moral education.

\section{$\mathrm{V}$ \\ ARISTOTLE'S REPLY to CoNTEMPORARY FeARS}

For deliberative democracy to be possible, the citizenry inust be more reflective as well as inore public spirited than in a pluralist or interest group deinocracy. The thesis of this Article is that the goal of a nore reflective citizenry inay be incapable of attainment if people do not possess certain character traits. The need for such character traits is suggested both by the doctrine that human beings are by nature political, as illuminated by Aristotle's teachings about the concept of nature as perfection, and by motivational questions inherent in the deliberative dynamic, as illuminated by Aristotle's teachings about practical reason.

This Part addresses several inportant objections that have been made to the view that deliberative deinocracy presupposes a moral foundation. The first objection arises from the fear that public encourageinent of even a minimal cluster of moral character traits, not to inention a comprehensive morality, will impede rather than enhance people's capacity for reflectiveness. This fear finds support in the proposition, which Aristotle would also endorse, that people's habits and passions can interfere with their ability to reason, or to act in accordance with the results of rational inquiry, if the habits and passions impel the person in a different direction than is dictated by the rational inquiry. ${ }^{231}$ We have no assurance that the character traits our government, or a inajority of our citizens, would consider desirable will be the proper traits to promote the deliberative qualities sought. As a consequence, any legislative inoral base line could lock us into an erroneous view of the world or, at the very least, predispose us toward ways-of-life at odds with our ultimate deliberative objective. Thus, according to this objection, as long as we lack complete certainty about the exact content of the inoral foundation for a deliberative society, our effort to establish a moral base line for the nation as a whole risks inpeding, rather than advancing, the deliberative project.

A second objection to encouraging certain character traits on a national or institutional basis does not presuppose that legislators would encourage harmful character traits while overlooking useful ones. The concern is rather that socialization of character traits is inherently at odds with the deliberative ideal. This concern depends upon the insight, also not foreign to Aristotle, that once habits of character are formed, people internalize the norms they einbody and desire the objects associated with those norms autonatically, and, thus, unreflectively. As a consequence, the very habits that prompt us to aspire towards deliberative citizenship could ultinately

231. See the discussion of Aristotle's views on choice and weakness of the will, supra Part HI.B. 
deprive us of our ability to accomplish this ideal by examining critically the values embedded in our own and alternative ways of life. If so, the socalled deliberative society would deliberate only about instrumental goals or technical issues, but not about its underlying values and ultimate purposes. In other words, in our haste to create a more reflective society, we may unnaturally and unacceptably narrow our concept of reflectiveness to questions of ineans rather than ends. This objection cuts deeper than the first because it suggests that the very notion of "programming" people to be rational citizens is incoherent-an idea at war with itself..$^{232}$

Finally, and a corollary of the preceding, is the concern that a publicly sponsored education encouraging practical wisdom and certain character traits will lead to a largely homogeneous population committed to a single conception of the good life. This result would be unacceptable to many, liberals and nonliberals alike, imcluding those with republican concerns, for reasons as various as the belief that choice, freedom, and autonomy are important elements of being human and the conviction that rational discourse itself presupposes airing and refining multiple points of view. ${ }^{233}$

These concerns express important issues raised by the thesis advanced in this Article. Although a complete response would entail a discussion of concrete practical measures designed to implement the moral foundation for deliberative democracy, ${ }^{234}$ I shall limit my present response to some of the theoretical issues at stake. Further, I shall focus my comments on aspects of Aristotle's writings that reveal that he took sucli concerns seriously.

\section{A. The Rational Capacity of Citizens}

Although Aristotle believed that most people need to develop praiseworthy habits of character before they can develop praiseworthy habits of mind, he attached great importance to the latter and inade clear the superior-

232. For a different view on the consequences for human life when adults are coerced into good conduct without becoming persuaded of its correctness or desirability, see Kimberly S. Dunn, Note, The Prize and the Price of Individual Agency: Another Perspective on Abortion and Liberal Government, 1990 DUKE L.J. 81, 85-88 (distinguishing between adults who are capable of right conduct and those who are not and concluding that compulsion is proper for the latter but it would limit the human possibilities of the former).

233. See Fallon, What Is Republicanism, and Is It Worth Reviving?, supra note 14, at 1698-99 (writing that "[m]ost [critics of classical republicanism] are skeptical that there is a uniform human nature capable of fulfillment only through politics, and the idea that republican pohtics would yield unanimity over the nature of the good strikes us as either delusive or tyrannical") (footnote omitted); Michelman, Traces of Self-Government, supra note 14, at 19-23, 31-32, 40-41 (arguing that from a modern liberal perspective, republicanism must be viewed as either foreclosing human possibihities or restraining individual self-direction).

234. For example, Mary Ann Glendon argues that our public discourse has adopted such a rigid and absolutist defense of rights-as compared with European countries, among others-that we have created a moral climate devoid of notions of duty or responsibility. In her view, if our public discourse were less extreme, we might make different decisions, or we imight reach the same results as we do now but for nuanced reasons that are more conducive to moral commitunents. See MARY ANN GLENDON, RIGHTS Talk: The Impoverisfament of Polmtical Discourse (1991). 
ity of people who combine the two types of attributes over people who possess praiseworthy character traits alone. For Aristotle, habituation to behave or refrain from behaving im a certain fashion out of fear of pumshment or through imitating authority figures is a prelude to the moral life, not its apex. This conclusion is the inescapable inference from Aristotle's doctrine that complete moral virtue is inseparable from practical wisdom ${ }^{235}$ as well as from his definition of choice as "mind with desire" (orektikos nous) or "desire with thought" (orexis dianoetike $\bar{e}$ ). ${ }^{236}$ It is also clear from passages in which Aristotle presents moral conduct based upon reason as more voluntary than comparable conduct not rationally grounded. ${ }^{237}$

Aristotle makes the same point implicitly in the Politics, while examining the question whether the good man and the good citizen have the same virtue or excellence (arete) $)^{238}$ Aristotle implies that two types of people deserve to be called "citizen," those who are fit to be ruled only and those who can both rule and be ruled. ${ }^{239}$ Both those who are fit only to be ruled and those fit to rule need the moral virtues; only the latter, however, possess practical wisdom. ${ }^{240}$ In contrast, those fit only to be ruled can get along with "true opimion" (doxa alethess) imstead of practical wisdom. ${ }^{241}$ In the best case citizens will exhibit the excellence of the ruler for they will possess practical wisdom, and they can rule and be ruled in turn. ${ }^{242}$ In short, Aristotle's conclusion is that the virtue of the good man and the citi-

235. Supra note 180; see COOPER, REASON AND the HUMAN GOOD IN ARISTOTLE, supra note 12, at 6-7, 61-64; ENGBerg-Pedersen, ARISTOTLE's TheORY OF MORAL INSIGHT, supra note 181, at 234-35 (practical wisdom is part of genuine moral virtue); KRAUT, ARISTOTLE ON THE HUMAN GOOD, supra note 86 , at 247 (stating that naturally virtuous qualities "must eventually be integrated with practical reason" before they become full or complete virtues); SALKEVER, FINDING THE MEAN, supra note 20, at 105-06; cf. Alfred R. Mele, Aristotle's Wish, 22 J. Hist. PHIL. 139, 156 (1984) (arguing that in Aristotle's view, when actions are chosen, they originate in dcsire whose context depends upon an internalized conception of the good to which intellect makes an important contribution).

236. Aristotle, Nicomachean Ethics 6.2 1139b4-5.

237. Id. at $9.81168 \mathrm{~b} 35-1169 \mathrm{al}$ (asserting that a person's "voluntary actions seem above all to be those involving reason") (Irwin trans., 1985).

238. ARISTOtLe, Politics 3.4.

239. See id. at $3.41277 \mathrm{a} 26-27$ (stating that the excellence of the citizen consists in being able to mle and be ruled); id. at $3.41277 \mathrm{~b} 11-13$ (stating that it is fine to say that one cannot rule well without baving been ruled); $i d$. at 3.4 1277b13-15 (stating that although the excellence of the two are different, the good citizen must know how and be able to be ruled and rule both). But see id. at 3.4 1277a20-23 (stating that the excellence of the citizen is not that of the ruler). Aristotle also notes that the people called "citizen" and the people who should be called "citizen" are not necessarily the same. Id. at 3.1. In particular, citizenship without qualification entails the ability to hold office; however, some of the people actually in office do not deserve this honor. Id. at $3.11275 \mathrm{a} 22-23,31-33 ; 1275 \mathrm{~b} 34-76 \mathrm{a} 8$.

240. Id. at $3.41277 \mathrm{~b} 25-27$ (nnaintaining that practical wisdom "is the only virtue peculiar to the ruler," whereas the virtues or excellences other than practical wisdom seem "necessarily [to] be common to both rulers and ruled" (Lord trans.)). But see id. at 3.4 1277b17-24 (stating that the justice and moderation of one who rules are different from those of one who is ruled, and moderation and courage are different for inen and women). On the practical wisdom of the ruler, see Zuckcrt, supra note 76 , at 195, 197-98 (emphasizing the intellectual component of the ruler's excellence).

241. Aristotle, Polmiti 3.4 1277b28-29.

242. Id. at $3.41277 \mathrm{~b} 13-16$. 
zen can be the same in the best state or regime, but that this will occur only for those people who are dehberative and thus truly citizens. ${ }^{243}$

Hence, Aristotle saw no bar in principle to citizens developing their rational capacities even after having been habituated to their society's moral norms. ${ }^{244}$ Although some citizens will become reflective while others will not, the difference cannot be explaimed in terms of their moral upbringing since both groups have this in common.

To explain how people can possess character traits that embody certain common values, yet retain the ability to examine and alter their character traits and values, one commentator has posited that our moral life can be divided into three stages. ${ }^{245}$ In the first, cliaracter traits are imitially acquired through habituation, training, and early moral education. In the second, the resulting character traits remain flexible and subject to adjustment. In the third, the character traits have become more or less fixed; as a result, they would be difficult, in some cases impossible, to change. According to this view, the first stage makes it possible for a person to acquire practical wisdom. In the second stage, practical wisdom has its greatest sway over a person's character and actions. Finally, once character traits become entrenched, whether from the passage of time or because they have been confirmed through practical reason, a person's ability to appreciate, or even adopt, a different way of life would become seriously himited.

This explanation clarifies several aspects of Aristotle's account of the relationship between practical wisdom and the moral virtues. ${ }^{246}$ However,

243. See id. at 3.4 1277b13-32, 7.14 1332b41-1333a16. In general, however, the virtue of the good man and the good citizen are not the same, because the virtue of the citizen is relative to the regime. Id. at $3.41276 \mathrm{~b} 29-34$. Even in the best regime, the virtue of the good man and the good citizen will not always be the same "since it is impossible for all the citizens to be similar." Id. at 3.4 1276b35-1277a13 (Lord trans.).

244. See Kraut, Aristotle on the Human Good, supra note 86, at 322-27 (arguing that the life consisting of nontheoretical virtues is a happy life for Aristotle to the extent that it is a life in accordance with reason); SALKEVER, FINDING THE MEAN, supra note 20, at 93-102 (emphasizing the importance for Aristotle of good upbringing and education for the development of virtue if people are to live a deliberative life); Jeremy Waldron, Particular Values and Critical Morality, 77 CALIF. L. REv. 561, 584 (1989) (arguing that Aristotle's views are more consistent with pluralism than are those of modern communitarians because he believed that human beings with differing views and experiences possess reason to converse rationally and not just to chant slogans); see also Nussbaum, Comments, supra note 20, at 227 (noting that the Stoics defend education as a means of producing people "capable of surveying the available conceptions of the good and producing good arguments for their own conception"). But see Ronald Beiner, Comment on Solum, 66 ChI.-KENT L. Rev. 141, 142 (1990) (noting that for Rousseau "the bonds of political community would dissolve if exposed to the cold glare of rational scrutiny"); T.H. Irwin, First Principles in Aristotle's Ethics, in 3 MIDWEST STUDIES IN PhILosophy: Studies in Ethical Theory 252, 255 (Peter A. French et al. eds., 1978) (concluding that people habituated to certain virtues cannot be rationally convinced to change their goals because "there is no rational practical argunent about ends").

245. The stages described in this paragraph are elaborated in Beatriz Bossi de Kirchner, On the Power of Practical Reason, 43 Rev. Metaphysics 47, 54-57 (1989).

246. For example, de Kirchner's tripartite analysis, see supra note 245 , suggests a reason why Aristotle sonuetimes speaks of practical reason as directed at both ends and means, whereas at other times he portrays it as directed toward means exclusively, see supra note 181 . In the second stage, 
Aristotle seems to make a bolder assertion when observing that the virtue of the citizen is relative to the constitution or form of government where he resides, whereas the virtue of the good man is everywhere the same. ${ }^{247} \mathrm{He}$ appears to identify the good ruler with the good man. ${ }^{248}$ A person who has the capacity for ruling will retain the ability to understand the character and limits of the norms promoted by his own pohtical community. Thus, in the best case, practical wisdom is not culture bound.

For Aristotle, then, people possessing practical wisdom can understand and evaluate their community's norms and aspirations without being blinded by them. This conclusion is consistent with the views of contemporary thinkers who maintain that, even though we always understand ourselves through the mediation of our surroundings and experiences, "[r]ecognizing the value of constitutive attachments does not preclude our making them the object of critical inquiry, examining their disadvantages and comparing them with other things of value."249 Aristotle's moral theory thus responds to the first two of the three fears sketched above, ${ }^{250}$ namely, that a publicly sponsored moral education could lock us in to a mistaken way of life or moral philosophy or that, regardless of the correctness of the values thus encouraged, such an education would reduce, rather than enhance, our capacity for reflectiveness. ${ }^{251}$

practical reason would be engaged in a study and evaluation of ends; in the third stage, it would be largely confined to instrunental determinations.

247. Aristotle, Politics 3.4 1276b30-34.

248. See id. at 3.41277 al4-21 (noting that we say that a good ruler is good and exercises practical wisdom, and discussing the consequences of this belief); $i d$. at $3.41277 \mathrm{a} 27-29$ (stating that if we posit that the excellence of the good man is ruling, whereas that of the citizen is both ruling and being ruled, then ruling and being ruled are not similarly praiseworthy).

249. Larmore, Patterns of Moral Complexity, supra note 219, at 94-96; see Macedo, LIBERAL VIRTUEs, supra note 214, at 40-50, $69-73$ (arguing that the core of liberalism is public reasonableness and a commitment to public justifications that are both thoughtful and widcly accessible and maintaining that the acquisition of "liberal virtues," such as moderation, perserverence, and selfcontrol, makes possible more rational individual lives as well as inore rational political discoursc and practices); Perry, MoralTTY, Polmtics, AND LAW, supra note 34, at 28-31 (arguing that our beliefs and opinions at any moment inake possible our ability to reason critically, ever though those beliefs and opinions are themselves subject to criticisin and revision). Macedo's view bears a superficial resemblance to that of Michael Perry. Howcver, Macedo builds his reflective society on a basis of provisional virtues and opinions, whereas the dynamic of Perry's reflective society centers on provisional opinions exclusively. Amy Gutmann takes the inore radical position that the state has an affirmative obligation to teach children to be reflective about different ways of life-that is, about ways of life different from the one they learn from their parents. GutMann, Democratic Education, supra note 97, at 28-33 (arguing that families have no more right to exclusive authority over the education of children than does the state and advocating that schools encourage children to evaluate their own and other ways of life critically). For a criticism of Gutmann's view, see WiLliam A. Galston, LiberAl PURPOSES, supra note 212, at 252-55 (arguing that the liberal state has the affirmative obligation to teach children tolerance of different ways of life, but not "to foster in children skeptical reflection on ways of life inherited from parents or local communities").

250. Supra text accompanying notes 231-32.

251. This appears to be the conclusion of Thomas Pangle, who supports a reinvigorated moral commitment to dennocracy while arguing that higher education in America should encourage students to undertake "a radical questioning of one's dcepest commitments and attachments, a radical scrutiny of 


\section{B. The Multiplicity of Human Types}

In responding to the concern that a publicly sponsored moral educational effort would create a homogeneous society with a single conception of the good life, it is useful to return to Aristotelian texts. In spite of the reliance of certain contemporary legal theorists on the Aristotelian dictum that human beings are by nature political, ${ }^{252}$ classical scholars and students of philosophy have long noted that Aristotle does not endorse this dictum unambiguously. For years a debate has raged about Aristotle's views on huinan nature and huinan happiness, animated by the presence in Aristotle's writings of at least two competing portraits of the ultimate end of human life: one of man as fundamentally political and one of inan as fundamentally contemplative. ${ }^{253}$ As formulated by scholars recently, the question is whether Aristotle viewed human happiness as essentially consisting in a single type of good or in multiple, inherently choiceworthy goods. ${ }^{254}$ In the

one's first premises, and hence of one's morals, pohitics, and religion." Thomas L. Pangle, The Ennobling of Democracy: The Challenge of the Postmodern Age 14-15, 155-59, 164-65, 183218 (1992). Note that Pangle would have institutions of higher learning encourage questioning, in contrast to Gutmann, supra note 249 , who advocates teaching children to reflect critically on their way of life in primary and secondary school.

252. See supra Part I.A.

253. See, e.g., COOPER, Reason AND Human GoOd in ARISTOtLe, supra note 12, at 89-182; Kraut, Aristotle on the Human Good, supra note 86, at 5, 15-17, 312, 320-27, 345-53 (describing the competing portraits of happiness and positing that the Nicomachean Ethics gives two answers to the question "what is happiness": in the best case, happiness consists in theoretical activity and in the second-best case, it consists in virtuous practical activity, in particular, the exercise of a pohtical leader's deliberative and moral virtues); J.L. Ackrill, Aristotle on Eudaimoma, 60 Proc. BRrr. ACAD. 339 (1974) (discussing both strands and concluding that Aristotle endorsed the comprehensive view of happiness); W.F.R. Hardie, Aristotle on the Best Life for a Man, 54 PHLosopHy 35 (1979) (describing the views of other commentators and concluding that Aristotle's view of happiness saw theorctical activity as paramount but did not require a total rejection of virtuous practical activity); Robert Heinaman, Eudaimonia and Self-sufficiency in the Nicomachean Ethics, 33 PHRONES1S 31 (1988) (examining the arguments commentators have advanced in support of the comprehensive view and concluding that perfect happimess consists of contemplation only, although conceding that other things may be intrinsically good); Thomas Nagel, Aristotle on Eudaimonia, 17 PHRONESIs 252 (1972) (describing the comprehensive as against the intellectualist interpretation of happiness and concluding that Aristotle favors the intellectualist view); Timothy D. Roche, Ergon and Eudaimonia in Nicomachean Ethics I: Reconsidering the Intellectualist Interpretation, $26 \mathrm{~J}$. Hist. PHIL. 175 (1988) (discussing the interpretations of Aristotle's view of happiness and adopting the conprehensive view).

254. The contrasting portraits of happiness in Aristotle's writings have been described in a number of ways. The contemplative portrait is usually characterized as exclusive or dominant, the opposing portrait as inclusive, bipartite, or mixed. As is noted by one commentator, many of these terms are ambiguous. In particular, a dominant end can be monolithic, valuing a single good or activity, but it could also be the higher ranked of two or more independently valued goods or activities. In the latter case, human happiness could include a plurality of constitutive ends that are hierarchically ranked. Ackrill, Aristotle on Eudaimonia, supra note 253, at 341.

The main textual support for the coinprehensive view of happiness occurs in Nicomachean Ethics 1.7, especially the passages where Aristotle says that happiness is an activity of "complete" virtue and is "self-sufficient." Some commentators interpret the passage in 1.7 to say that the comprehensive portrait of happiness consists in a person having all the virtues or excellences or all good things. See Ackrill, Aristotle on Eudiamonia, supra note 253, at 345-54; John M. Cooper, Contemplation and Happiness: $A$ Reconsideration, 72 Synthese 187, 200-04 (1987); Timothy D. Roche, Review of Kraut, 101 PhIL. Rev. 629, 630 (1992); see also Heinaman, Eudaimonia and Self-sufficiency in the Nicomachean Ethics, 
former case, the ultimate end of being human is usually equated with the philosophic life. The virtues central to moral or political life are choiceworthy only if, and to the extent that, they contribute to the possibility of theoretical activity. In contrast, if the human end is comprehensive, both the virtues central to moral and political life and those integral to the contemplative life would be constitutive of human happiness. ${ }^{255}$ Neither

supra note 253, at 31 n.2 (listing authorities); A.W. Price, Aristotle's Ethical Holism, 89 Mind 338, $342-43$ (1980) (distinguishing between a holistic and an atomistic version of the "all-good-within" view of Nicomachean Ethics 1.4 and 1.7: in the former case, the component goods are good because they fall under the defimition of happiness; in the latter case the elements of happiness are intrinsically good and fall within happimess as a consequence). However, in Nicomachean Ethics 1.7 1098a16-18, Aristotle also indicates that happimess consists in the best and most complete virtue, which formulation may suggest a single dominant virtue. See id. at 1.8 1099a29-31 (asserting that his definition of happiness identifies happiness with the best activities or with the one best activity). For a reconciliation of these seemingly contradictory strands of the discussion of happiness in Book 1, see Cooper, Contemplation and Happiness: A Reconsideration, supra, at 197-204.

The main textual support for the contemplative portrait of happiness occurs in Nicomachean Ethics 10.7-.8. See A.W.H. Adkins, Theoria versus Praxis in the Niconnachean Ethics and the Republic, 73 Classical PHII. 297 (1978) (acknowledging the places in Aristotle's writings that depict practical virtue as choiceworthy, but arguing that real happiness for Aristotle involves contemplation exclusively and that Aristotle never resolves the conflict between the theoretical and practical lives); Heinainan, Eudaimonia and Self-sufficiency in Nichomachean Ethics, supra note 253, at 32-35 (arguing that Nicomachean Ethics 1.7, as well as the Tenth Book, refers to the exclusively contemplative portrait); see also KENNY, THE ARISTOTELIAN ETHICs, supra note 12, at 190, 203-06 (arguing that the first book of the Nicomachean Ethics identifies happiness with contemplation exclusively, whereas the Eudemian Ethics adopts a more inclusive portrait of happiness).

A few cominentators have concluded that Aristotle's works deliberately present two views of human happiness. For example, although Kraut concludes that the Nicomachean Ethics is primarily intellectualist, he claims that Aristotle presents two freestanding, compatible views of happiness, the best version and the second-best version. KRAUT, ARISTOTLE ON THE HUMAN GOOD, supra note 86, at 320-27, 345-53; see COOPER, REASON AND HuMAN GOOD IN ARISTOTLE, supra note 12, at 175-79 (concluding that in Book 10 of the Nicomachean Ethics Aristotle endorses the technical, intellectualist psychology of the De Anima, but that because he retains respect for the common sense view that the essence of human beings cannot be identified with mind alone, Aristotle still presents the "mixcd life" as a flourishing one). Contrast the view of Troels Engberg-Pedersen, who argues that for Aristotle happiness consists of a combination of the theoretical life and the life of moral action, but nonethelcss concludes that because human beings are naturally social, the claims of moral behavior "take precedence" over the claims of the theory. ENGBERG-PEDERSEN, ARISTOTLE's TheOrY of Moral INSIGHT, supra note 181, at 108-09, 115-21. Reason itself teaches that "one's own interests and those of the eommunity become identical." Id. at 47.

255. See supra note 254 (citing authorities who construe happiness for Aristotle as combining theoretical and practical excellence, even though the former is more valuable than the latter); see also Sherman, Fabric of Character, supra note 83, at 97-103 (arguing that practical excellence has as its ultinate object to "repair a damage," i.e., war or instability, whereas theoretical excellence is sought for its own sake, but concluding that the human good includes the practical excellences constitutively beeause these coinplete certain aspects of our humanity); Smith, supra note 84, at 16-17, 24-25 (arguing that the cultivation of mind is the highest human good, but that the moral virtues are independently choiceworthy components of happiness).

Two recent commentators have argued that one of Aristotle's objectives was to refine the Athenian notion of politics to make it less extreme in its commitunent to manliness, spiritedness, and related attributes of character. Carnes LORD, Education and Culture in the Polttical Thought of ARISTOTLE 192, 200-02 (1982); SALKEVER, Finding THE MEAN, supra note 20, at 168-69, 178-81, 186 (arguing that Aristotle's biology is the basis of a critique of the Greek celebration of virility and courage and an attempt to elevate the virtues, such as moderation, which are devoted to peace and leisure). Note 
would be sought for the sake of the other, and neither could be sacrificed in the name of the other.

It is beyond the scope of this Article to attempt to resolve this ambiguity in Aristotle's philosophy. Three points related to the controversy are relevant to the concerns raised by the thesis of this Article. First, the ambiguity in Aristotle's writings and the controversy it has spawned can be traced to the fact that Aristotle was a dialectical, not a dogmatic, philosopher. On the most elusive and perennial moral question, namely, what is the best way to live, he was keenly aware of the power of competing visions of the good hife and his works were designed to reflect that awareness. ${ }^{256}$ Thus, while it may be true that Aristotle beheved that political hife provides a unique opportunity for certain human attributes to reach their fullest development, he did not endorse a single vision of the good life. Despite this - and although his account of such things as human action, choice, and weakness of the will also contain many ambiguities-Aristotle was consistent in his view that rational beliefs cannot by themselves explain what moves people to act or refrain from acting. Regardless of the portrait of human happiness or the good life Aristotle ultimately favored or found most persuasive, his view that moral virtue must align itself with reason before reason can motivate action was unwavering. ${ }^{257}$ The implication is that for Aristotle the view that a rational life presupposes a moral foundation is not tied to a specific conception of the good much less to the portrait of human happmess as fundamentally political; rather it is valid with respect to other conceptions of the good, especially a life devoted to imquiry and reflection. ${ }^{258}$

Second, this interpretation is also suggested by the structure of the Nicomachean Ethics. This work begins by addressing the question of the meaning of happiness or the best way to live. ${ }^{259}$ The tentative conclusion

also that for Salkever, Aristotle did not view our political nature as our deepest nature, but rather as one consequence of human rationality. Id. at 57-104, 179-80.

256. For a different interpretation of the reason why Aristotle gives no definitive answer to the question of the best life, see Nagel, Aristotle on Eudaimonia, supra note 253, at 253 ("It is beeause he is not sure who we are that Aristotle finds it difficult to say unequivocally in what our eudaimonia consists ...."). Aristotle was also keenly aware of the power of the claims that pleasure and wealth make up human happiness, but he rejected these claims. See Aristotze, NicomaCHEAN Etrics at 1.4-5, 10.6-7.

257. In particular, these doctrines appear both in the Books of the Nicomachean Ethics that seem to presuppose the centrality of the practieal virtues and in the De Anima, which reflects the intellectualist view developed in Book 10 of the Nicomachean Ethics.

258. The same conclusion is reached by Jeremy Waldron based upon Aristotle's statement that "Nature ... does nothing without sone purpose; and for the purpose of making man a political animal she has endowed him alone among the animals with the power of reasoned speech." Waldron, Particular Values and Critical Morality, supra note 244, at 561, 584 (citing the Sinclair translation). According to Waldron, Aristotle links man's reasoning capacity to his political nature because of his belief that "we can hope as a community to attain knowledge of goodness and justice only by conversation among people who bring different views, perspectives and experiences to political life." Id.

259. Aristotre, NicomachEan Etrics 1.2 (asking whether, assuming that there is a final or best human good that is sought for its own sake, we should try to identify it so that we will have a target to 
reached early in the work is that happiness involves a life of activity in accordance with "reason" or "reasoning."260 However, there is no attempt to flesh out the details of the type of reason intended. The work goes on to develop a theory of the moral virtues and practical reason that is driven by the portrait of man as a political animal. ${ }^{261}$ In contrast, the last three books of the Nicomachean Ethics veer in a different direction. The Eighth and Ninth Books discuss friendship, a relationship that is fundamentally private. $^{262}$ The last book of the Nicomachean Ethics elaborates the portrait of the contemplative life as the highest form of human happiness, a life wholly private and opposed to the pohtical life in a decisive respect. ${ }^{263}$ The essence of the contemplative life is antithetical to the essence of political life in that the former accepts no truths on the basis of tradition, authority, precedent, or popular acceptance. Viewed from the perspective of citizenship and the body politic, the contemplative life is subversive because it takes nothing as a given and defers to no authority except reason.

Regardless of whether we accept Aristotle's endorsement in the Tenth Book of the superiority of the contemplative life over other possibilities, it is clear that he recognizes the chasm separating the life of the philosopher from the life of the citizen. ${ }^{264}$ Yet his discussion of the contemplative alternative, and the preceding discussion of friendship primarily in private terms, never repudiate his account of the moral virtues elaborated in the Second through Seventh Books. The implication from the structure of the book thus is that to some degree the training for citizenship and the training

aim at in the conduct of our lives); id. at 1.4-.13 (reviewing the common opinions about happiness as well as the opinions of famous people and reaching a provisional and general statement as to its nature).

260. See id. at 1.7 1097b28-1098a20 (suggesting that the highest function of human beings is the active exercise of reason and asking if it does not follow that the human good consists in achieving this state).

261. Id. bks. 2-7.

262. Aristotle indicates that friendship may benefit cities by creating bonds among the citizens. Id. at 8.2 1155a23-27. However, the larger discussion does not focus on this aspect of friendship, and the three basic types of friendship (for utility, for pleasure, and between good people who wish one another the good) do not presuppose a political purpose. Although friendship is characterized as "the choice to live together," ARISTOTLE, PoLmics 3.9 1280b38-39, "living together" does not necessarily imply a political relationship, since the latter has as its object "living well." Id. 3.9 1280b39. For a contrasting view, sce Benner, Polmical Judgment, supra note 172, at 82 (coneluding from an analysis of judgment in the Nicomachean Ethics that "friendship is quintessentially political"). On Aristotle's doctrine of friendship, see Sherman, FABric of Character, supra note 83, at 133-56; John M. Cooper, Aristotle on Friendship, in Essays on ARISTOTLE's ETHIcs, supra note 79, at 301, 301-40.

263. ARISTOTLE, Nicomachean Ethics 10.7-.8.

264. Mary Nichols offers an interpretation to bridge this chasm by arguing that the philosopher needs engagenient in political life of a certain kind to complete his philosophic inquiries. The politics that fills this need is deniocratic by virtue of being participatory, and it is aristocratic by emphasizing the need for virtue. Nichols, Crtizens AND STATESMEN, supra note 20, at 8-9. However, she also observes that the philosopher's ultimate goal remains understanding. Id. at 9. Moreover, Nichols points to Aristotle's awareness of the potential "destructive effect" that philosophy can have on political life. Id. at 40-41 (describing Aristotle's criticisn of the proposals for political reform presented in Plato's Republic). See W.D. Ross, ARISTOTLE 238 (1923) (asserting that political life inakes possible more intellectual stimulation than does subpolitical life and also enlarges the scope of moral activity). 
for a life of questioning and reflection coincide or, at the very least, that training for citizenship does not preclude the pursuit of alternative ways of life. $^{265}$

Finally, the last chapter of the Nicomachean Ethics argues for the necessity of moral education undertaken by the government and anticipates in a general way the subjects treated in the Politics. ${ }^{266}$ As a consequence, the Politics appears as the continuation or completion of the Nicomachean Ethics; the project of the Politics is thus to discuss the types of government and institutions that will realize the objectives discussed in the Nicomachean Ethics. ${ }^{267}$ The transition between the Nicomachean Ethics and the Politics together with the organic relationship between the two books thus suggest that Aristotle believed that the moral virtues discussed in the former work are conpatible with a multiplicity of human types.

This is not to say that Aristotle viewed the proposed moral education as compatible with all conceptions of the good. On the contrary, the purpose of ethical training was to circuniscribe the range of likely hunıan types. ${ }^{268}$ It is, however, to stress that Aristotle begins his odyssey in the

265. This interpretation is buttressed by the absence in Aristotle's works of something comparable to the special education of philosophers that appears in Plato's Republic. The absence of such a program for philosophers suggests that there is a common initial education for those whose lives will culminate in citizenship and those whose activities will culminate in the philosophic life. My interpretation of the structure of the Nicomachean Ethics appears on the surface to differ from that of Cooper and Kraut, both of whom behieve that Aristotle is presenting alternative, and not necessarily complementary, ways of life. See supra note 253. In his book, Cooper argues that Aristotle's characterization of the inoral and political life as second best in Nicomachean Ethics 10.7 1178a6-9 requires the conclusion that a person committed to a life of contemplation "is beyond ordinary moral virtue. . . . Moral virtue remains . . . an ingredient exclusively of the mixed ideal." COOPER, REASON AND Human Good in ARistotle, supra note 12, at 179; see id. at 148, 150, 163-65; Cooper, Contemplation and Happiness: A Reconsideration, supra note 254, at 191-94. In my view, even if Cooper is correct that the adult pursuing a life of contemplation will not be conimitted to moral virtue, it does not follow that for Aristotle children who will become such adults should receive in their formative years noral education and training different from that received by those who will ultimately pursue a different way of life. Rather, such aduits will "be beyond ordmary moral virtue" in that they will no longer pursue this type of excellence for its own sake-a condition of ordinary moral virtue. See ARIstotle, Nicomachean EthIcs 2.4 1105a32. But see MoNAN, Moral KNowledge and Its METHODOLOGY IN ARISTOTLE, supra note 12, at 113-14, 131-33, 151 (arguing that the identification of happiness with the theoretical life in Book 10 represents the early Aristotle of the Protrepticus period and was superseded by the moral theory in the earlier Books of the Nicomachean Ethics); MARTHA C. Nussbaum, The Fragiltiy of Goodness: Luck and Ethics in Greek Tragedy and PhILOsophy 373-77 (1986) (arguing that the intellectualist account of Book 10.6-8 is fiatly iuconsistent with the rest of the Nicomachean Ethics and concluding that these chapters were probably added to the text by someone other than Aristotle after the work was complete).

266. ARISTOtLe, Nicomachean EthICs 10.9. For a contrary view of the relationship betwecn the last chapter of the Nicomachean Ethics and the Politics, see Carnes Lord, The Character and Composition of Aristotle's Politics, 9 POL. THEORY 459, 472-73 (1981) (arguing that the brief outline of the Politics in the last chapter of the Nicomachean Ethics does not accurately describe the contents of the Politics and advancing the view that the last cliapter may have becn added by soneone other than Aristotle and the Politics itself nuay be a work of Theophrastus).

267. On the relationship between the two works, see works cited supra note 12.

268. See Hirshman, The Book of " $A$," supra note 18, at 983-84 (noting that Aristotelian ethics circumscribe to some degree the good life and illustrating this with his rejection of two extreme views 
Nicomachean Ethics with a hypothetical: "If, then, there is a single end at which our actions aim ... would not knowledge of this best good be important for how we live our lives?"269 The hypothetical is never unambiguously answered in that work and students of the Nicomachean Ethics have never reached agreement as to the author's probable conclusion. The consequence is that Aristotle's practical philosophy preserves a degree of openness to the luman possibilities. Far from dictating a single outcome, his works invite, indeed compel, readers to undertake their own review of the evidence and arguments presented.

\section{ConcLusion}

Aristotle was no democrat. As is well known, Aristotle divided forms of government (or "regime") into correct and incorrect, ${ }^{270}$ and he classified democracy among the incorrect forms of government. ${ }^{271}$ In important respects, moreover, Aristotle's proposals for an ideal or best regime were highly exclusionary. Women and natural slaves were to be excluded froin participation in political life, as were inen who lacked a certain level of property and a certain type of education and experience. ${ }^{272}$ As a consequence, it is fair to ask whether we should take seriously his views on liuman nature, character, and reason if it seems probable that we will be unwilling to be equally receptive to his political theory. ${ }^{273}$

I believe that the answer is "yes" for several reasons. First, as was noted earlier, ${ }^{274}$ it is inaccurate to speak about Aristotle's views as though he were a systematic or dogmatic writer. The dialectical character of Aristotle's writings enhances the relevance of his practical philosophy for conteinporary theory because it is evidence that he does not in general atteinpt to lock the reader into a specific political program. Although in soine instances Aristotle appears to reach closure on inportant issues, in

about the correct status of private property); Martha C. Nussbaum, Non-Relative Virtues: An Aristoselian Approach, in 13 Mmwest Studies in PhILOsophy: Ethical Theory: Character and Virtue 32, 32 36 (Peter A. French et al. eds., 1988) (enumerating 11 characteristics of any moral theory). At the same time, as several commentators have noted, heterogeneity is central to the political philosophy of Aristotle, as contrasted with that of Plato. See, e.g., Bernard Yack, Community and Conflict in Aristotle's Political Philosophy, 47 Rev. PoL. 92, 94 (1985); see also id. at 101 (heterogeneity makes possible self-sufficiency).

269. Aristotle, Nicomachean Ethics 1.2 1094a18-23.

270. ARISTOTLE, PoLtTICS 3.7 1279a22-31.

271. Id. at 3.7 1279b4-9 (classifying democracy as a deviation from "polity," because in democracy the many poor rule im their own interest, whereas in "polity" the many rule for the common good).

272. Id. at 3.9 1280a31-34 (asserting that natural slaves and animals cannot be part of a state since they do not share in happimess or a life that is chosen); id. at $7.91328 \mathrm{~b} 39-1329 \mathrm{a} 2$ (maintaining that citizens cannot be farmers because they need leisure for acquiring virtue and engaging in political activity); id. at 1329a17-26, 34-38.

273. See Wallach, Contemporary Aristotelianism, supra note 213, at 613-15 (observing that contemporary thinkers of widely disparate views all claim Aristotle as their intellectual ancestor and asking what are the limits of reasonable use of Aristotle's philosophy).

274. Supra notes 19-20 and accompanying text. 
others, the inquiry remains provisional, at most probative rather than dispositive. ${ }^{275}$ Thus, we can take his writings seriously because they shed light on the underlying issues. In particular, his writings clarify the important questions to ask and the strategies we should adopt so as to explore such questions coinprehensively and fairly.

Second, although Aristotle's political views can be said to presuppose his views on human nature and human psychology, the reverse is not necessarily true. His views on human nature and psychology, even if believed, do not require that we similarly endorse his political theories. The reason is that to a significant degree, Aristotle's political theories reflect his historical situation as well as his understanding of universal truths about human nature. To put it in Aristotehan terms, his political thought is a product of both practical reason and theoretical wisdom. To the extent that his imsights derive from theoretical inquiry, they will tend not to change as practical realities change; ${ }^{276}$ to the extent that they derive from practical reason, in contrast, they may be adjusted to fit changing circumstances.

To illustrate this point, one interpretation of Aristotle's exclusionary political theory emphasizes that his reason for excluding certain groups from politics was his belief that citizenship and participation in political life are impossible without considerable leisure and education. ${ }^{277}$ Since leisure and education are more widely available in today's liberal democracy than they were in classical Greece, this change in circuunstances may justify, or even require, altering the views on citizenship expressed in Aristotle's Politics. ${ }^{278}$ In other words, if Aristotle did not exclude certain classes of people from citizenship because they were intrinsically incapable of citizenship, but ouly as a means to ensure an end that can be accomplished today without resorting to such drastic measures, then many of the exclusionary aspects of his political thought would be instrumental and not choiceworthy in their own right.

Finally, Aristotle's antideinocratic bias may have been exaggerated by contemporary writers. In recent years, several commentators have begun to focus on those strands of Aristotle's writings that speak to the strengths of

275. Terence Irwin reaches a similar result by virtue of his distinction between a stronger and a weaker form of dialectic. See IRWIN, ARISTOTLE's FIRST PRINCIPLES, supra note 19, at 416. Based upon his distinction, he accepts those of Aristotle's ethical principles that are sound and uses them to "correct some of Aristotle's political recommendations" that are unsound. Id. at 415-16.

276. Of course, certain theoretical insights theinselves address the impact of cbanging circumstances.

277. On Aristotle's understanding of the importance of leisure, see Irwin, ArISTOTLE's First Principles, supra note 19, at 411-14. Irwin challenges Aristotle's conclusion that people who perform manual activities are unsuited to be citizens by arguing that sucb people may still have enough leisure to qualify as citizens under Aristotle's own account of citizenship. Id. at 414-15.

278. Martha Nussbaum appears to interpret Aristotle thus. See Nussbaum, Comments, supra note 20 , at 227-28 (suggesting that the exclusion of certain groups from politics was necessitated by the need for some groups to ensure the support and education of others and observing that Aristotle hints that he wishes the menial tasks could be provided by outsiders rather than residents of the political community). 
certain forms of democratic government. ${ }^{279}$ These authors point to passages in the Politics claiming such things as the superiority of the collective judgment of the multitude over that of a few talented or expert people in some situations, ${ }^{280}$ Aristotle's ranking democracy as the best of the incorrect regimes, ${ }^{281}$ and his endorsement of polity, which involves rule by the population as a whole, as the most realistic of the correct forms of government. ${ }^{282}$

279. Mary Nichols summarizes this change in attitude on the part of political theorists and feminists. Nichols, Crtrzens and Statesmen, supra note 20, at 1-3. Nichols' own interpretation of Aristotle's pohtical philosophy builds upon both the democratic and the aristocratic strands of his writing. See id. at 5-9; see also BeINER, PolmiCAL JUDGMENT, supra note 172, at 90-92, 163 (adopting in his own name Aristotle's view that ordinary citizens without technical training may be capable of possessing the kind of political judgment that is necessary for political participation); Andrew Lintott, Aristotle and Democracy, 42 CLAssical Q. 114 (1992) (arguing that Aristotle's hostility to democracy is nost pronounced in the case of "extreme democracy" and that he presents several powerful arguments in support of certain subclasses of democracy); Solum, Virtues and Vices, supra note 14, at 129-31 (arguing, based upon the works of Aristotle, Gutmann, and Mill, that democracy enhances the commumicative virtues essential to political life). Martha Nussbaum argues that a distinction should be made within the classical philosophic tradition between philosophers who are elitists and those who are perfectionists. The elitists, according to Nussbaum, believe that by virtue of their natural endowments many people are unfit for citizenship and participation in political life. Nussbaum, Comments, supra note 20, at 220-21. Perfectionists, in contrast, consider certain human attributes and skills a condition of citizenship and political participation; however, they do not assume that most people are unfit to acquire these characteristics. Although there are different perfectionist traditions, they share the belief that people can in general acquire the necessary attributes and skills through education and training. Id. at 221,229 . According to Nussbaum, Aristotle combined the elitist and the perfectionist traditions. On the perfeetionist side, he believed that the virtues needed for citizenship and participation in political life were attainable by a large portion of the male population. Id. at 221-22. Nussbaum connects this observation to Aristotle's proposal in the Politics that the government provide subsidies to enable poor people to attend common meals, which he considered "an important part of civic social functioning," and to possess a certain level of private property. Id. at 222; cf. Thomas Lindsay, Aristotle's Qualified Dcfense of Democracy through Political Mixing, 54 J. Pol. 101 (1992) (arguing that Aristotle was not simply a democrat or an antidemocrat; he limits participation in politics by the multitude, and he believes education inust always be combined with force because mass enlightenment is impossible); W.R. Newell, Superlative Virtue: The Problem of Monarchy in Aristotle's 'Politics,' 40 W. PoL. Q. 159, 175 (1987) (arguing that despite Aristotle's qualified endorsement of inclusiveness and diversity, his politics are megalitarian in principle because he "cannot embrace the notion that there is no higher order of virtue in principle than that of which every human being is capable").

280. Aristotze, Polmes 3.6 (discussing the view that the many individuals with lesser virtue, when joined together, may be superior to a single individual possessing much virtue if the partial virtue of the many individuals can be aggregated). For an extended discussion of these passages, see Lindsay, Aristotle's Qualified Defense of Democracy Through "Political Mixing," supra note 279, at 103-09 (arguing that Aristotle's arguments for the collective superiority of the multitude's judgments in ccrtain matters are subsequently qualified and replaced by the more modest claim that the multitude should be included in government because of its ability to destroy the city and ultimatcly by the claim that a certain type of mixed regime under law is better than a pure democracy or a pure oligarchy); see also Lintott, Aristotle and Democracy, supra note 279, at 117-18, 124 (discussing the limits of the argument for collective virtue); id. at 118-21 (noting the varieties of democracy discussed by Aristotle and emphasizing the hierarchy among the different varieties).

281. See ArIstotle, Polmics 4.11 1296a13-16 (observing that democracies are more stable and pernanent than oligarchies because of the size and status of the middle class); id. at $4.21289 \mathrm{a} 38$ $1289 \mathrm{b5}$ (ranking tyranny the worst and democracy the best of the incorrect regimes).

282. See id. at $3.71279 \mathrm{a} 22-29$ (classifying polity (politeia) among the three correct fonns of government); id. at $4.21289 \mathrm{a} 26-28$ (same); id. at 4.11 (raising the possibility that the best regime 
The contemporary appropriation of Aristotle's dictum that human beings are by nature political has in common with its Aristotelian source a belief in the centrality of deliberative activity for human fulfillment, but it departs from its source by assuming that virtually all people are born capable of exercising deliberation at will. Aristotle's account of the psychology of human action-especially the interaction of reason and character-contradicts this assumption. His analysis of these issues is forceful enough to warrant our close attention. In the end, however, we, like Aristotle, must make up our own minds.

absolutely is different from the best regime for most communities and suggesting that polity is the best regime in the latter sense); see also William T. Bluhm, The Place of "Polity" in Aristotle's Theory of the Ideal State, 24 J. PoL. 743 (1962) (arguing that the characteristics of the absolutely best regime are derived from those of polity); Lintott, Aristotle and Democracy, supra note 279, at 116-17 (arguing that the true polis is a species of democracy). 
